\title{
NISTIR 5189
}

\section{WIND LOAD PROVISIONS OF THE MANUFACTURED HOME} CONSTRUCTION AND SAFETY STANDARDS - A REVIEW AND RECOMMENDATIONS FOR IMPROVEMENT

Richard D. Marshall

Building and Fire Research Laboratory

Gaithersburg, Maryland 20899

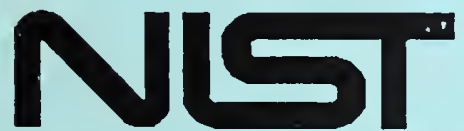

United States Department of Commerce

$$
\text { nology Administration }
$$

QC nal Institute of Standards and Technology 



\section{WIND LOAD PROVISIONS OF THE MANUFACTURED HOME CONSTRUCTION AND SAFETY STANDARDS - A REVIEW AND RECOMMENDATIONS FOR IMPROVEMENT}

Richard D. Marshall

May, 1993

Building and Fire Research Laboratory

National Institute of Standards and Technology

Gaithersburg, MD 20899

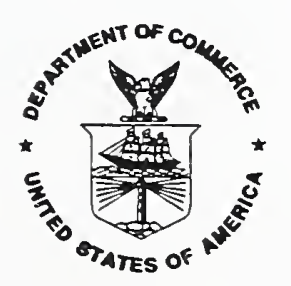

U.S. Department of Commerce

Ronald D. Brown, Secretary

National Institute of Standards and Technology

Raymond D. Kammer, Acting Director
Prepared for:

Department of Housing and Urban Development

Washington, DC 20410 



\begin{abstract}
Limited wind speed measurements obtained during landfall of Hurricane Andrew in south Florida and wind speed estimates obtained from a computer-based model and from analyses are summarized and compared with code-specified design speeds for the affected area. Published reports of wind damage to manufactured homes and to conventional wood-framed dwellings are reviewed to identify modes of failure and intensity of damage. In general, manufactured homes which were built subsequent to issuance of the Manufactured Home Construction and Safety Standards (MHCSS) suffered less damage than did units built prior to issuance of the MHCSS. However, conventional residential construction performed better than did manufactured homes, including HUD-labeled units. Wind load provisions of selected codes and standards are compared and it is concluded that ASCE Standard 7-88 (Minimum Design Loads for Buildings and Other Structures) should be the basis for upgrading and improving the current wind load requirements of the MHCSS. Draft wind load requirements of the HUD Proposed Rule are reviewed and it is concluded that some clarification and refinement of these requirements are in order.
\end{abstract}

Keywords: building technology; codes and standards; hurricanes; manufactured homes; mobile homes; natural disasters; structural engineering; wind damage; wind engineering; wind loads. 


\section{TABLE OF CONTENTS}

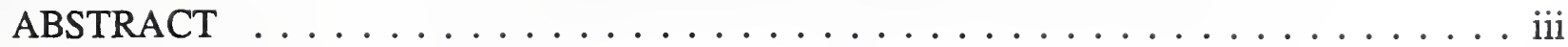

LIST OF TABLES $\ldots \ldots \ldots \ldots \ldots \ldots \ldots \ldots \ldots \ldots \ldots \ldots \ldots \ldots$

LIST OF FIGURES $\ldots \ldots \ldots \ldots \ldots \ldots \ldots \ldots \ldots \ldots \ldots \ldots \ldots$

LIST OF ACRONYMS $\ldots \ldots \ldots \ldots \ldots \ldots \ldots \ldots \ldots$ ix

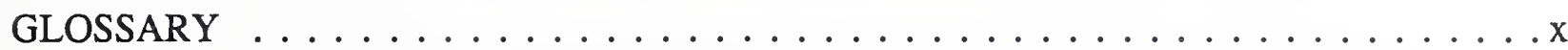

EXECUTIVE SUMMARY $\ldots \ldots \ldots \ldots \ldots \ldots \ldots \ldots \ldots \ldots \ldots \ldots \ldots \ldots$

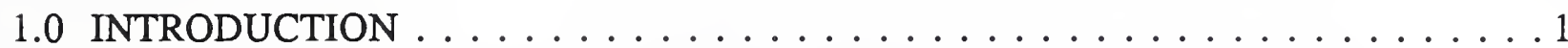

2.0 WIND SPEEDS IN HURRICANE ANDREW $\ldots \ldots \ldots \ldots \ldots \ldots \ldots$

2.1 Recorded Wind Speeds $\ldots \ldots \ldots \ldots \ldots \ldots \ldots$

2.2 Predictive Models $\ldots \ldots \ldots \ldots \ldots \ldots \ldots \ldots$

2.3 Comparison of Predicted Speeds . . . . . . . . . . . . . . 7

2.4 Conversion to Fastest-Mile Speeds $\ldots \ldots \ldots \ldots \ldots$. . . . . . 8

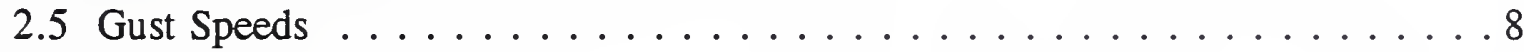

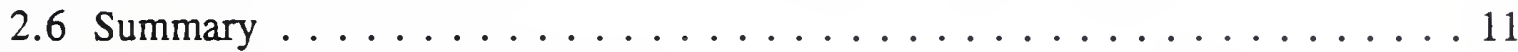

3.0 OVERVIEW OF WIND DAMAGE $\ldots \ldots \ldots \ldots \ldots \ldots \ldots \ldots \ldots$

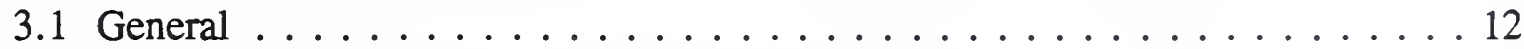

3.2 Conventional Wood-Framed Dwellings . . . . . . . . . . . . . 12

3.2.1 American Plywood Association Study . . . . . . . . . . 12

3.2.2 American Forest \& Paper Association Study . . . . . . . . . . 13

3.3 Manufactured Housing . . . . . . . . . . . . . . . . . . . . . 14

3.3.1 American Plywood Association Study . . . . . . . . . . 15

3.3.2 Manufactured Housing Institute Study . . . . . . . . . . . . . 16

3.3 .3 NCSBCS Study . . . . . . . . . . . . . . . . . 20

3.3.4 Florida Manufactured Housing Association Study . . . . . . . . . 23 


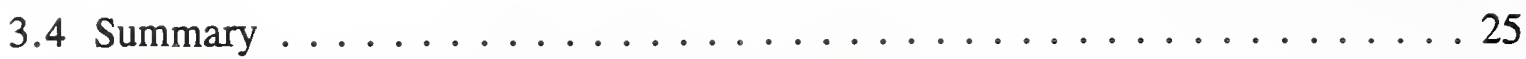

3.4.1 Conventional Wood-Framed Dwellings . . . . . . . . . . 25

3.4 .2 Manufactured Housing . . . . . . . . . . . . . 25

4.0 COMPARISON OF DESIGN WIND LOADS . . . . . . . . . . . . 27

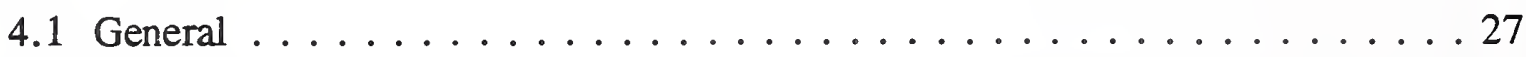

4.2 ASCE Standard 7-88 (Minimum Design Loads for Buildings

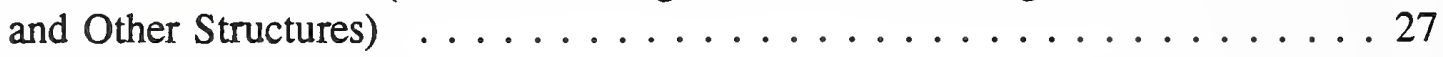

4.3 Manufactured Home Construction \& Safety Standards (MHCSS) . . . . . . 29

4.4 South Florida Building Code $($ SFBC-88) . . . . . . . . . . . . . . . 29

4.5 Standard Building Code $($ SBC-91) . . . . . . . . . . . . . . . . 30

4.5.1 The 0.8 Factor Applied to SBC-91 . . . . . . . . . . 31

4.6 Manufactured Housing Institute (Proposed Requirements) . . . . . . . . . 32

4.7 Comparison of Design Loads . . . . . . . . . . . . . . . . . . . 33

4.7.1 Structural Stability . . . . . . . . . . . . . . . 34

4.7.2 Main Wind Force Resisting System (MWFRS) . . . . . . . . . 34

4.7 .3 Components and Cladding . . . . . . . . . . . . 35

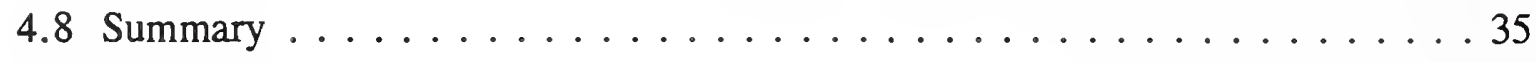

5.0 HUD PROPOSED RULE . . . . . . . . . . . . . . 51

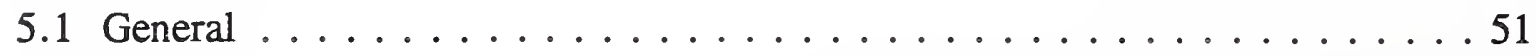

5.2 Assumptions and Limitations . . . . . . . . . . . . . . 51

5.3 Review of Proposed Design Wind Forces . . . . . . . . . . . . . 58

5.3.1 Anchorage for Lateral \& Vertical Stability . . . . . . . . . . . . 58

5.3 .2 Main Wind Force Resisting System . . . . . . . . . . . . . . 59

5.3 .3 Components and Cladding - Roofs . . . . . . . . . . . 60

5.3.4 Components and Cladding - Walls . . . . . . . . . . . . 62

5.3.5 Components and Cladding - Bottom Board . . . . . . . . . . 63

5.4 The Significance of Internal Pressures $\ldots \ldots \ldots \ldots . \ldots . \ldots 6$

5.5 Summary and Recommendations . . . . . . . . . . . . . 64 
6.0 MAJOR FINDINGS AND RECOMMENDATIONS . . . . . . . . . . 66

6.1 General . . . . . . . . . . . . . . . . . 66

6.2 Major Findings . . . . . . . . . . . . . . 66

6.3 Recommendations . . . . . . . . . . . . . . . . . . . 69

7.0 REFERENCES . . . . . . . . . . . . . . . . 71

ACKNOWLEDGMENTS $\ldots \ldots \ldots \ldots \ldots \ldots \ldots \ldots \ldots \ldots \ldots$

APPENDIX ..........................

\section{LIST OF TABLES}

Table 1. Summary of Wind Speed Observations in Hurricane Andrew . . . . . . . . 3

Table 2. Upper-Bound Estimates of Fastest-Mile Wind Speeds for Selected Locations . . 7

Table 3. Wind Damage Classes for Manufactured Homes . . . . . . . . . . . . . 16

Table 4. Manufactured Home Parks Surveyed by Ferguson and Cardwell . . . . . . . 17

Table 5. Manufactured Homes in Dade County Destroyed or Rendered Uninhabitable . . 24

Table 6. Comparison of Design Wind Loads for Hurricane-Prone Regions . . . . . . . 37

Table 7. Design Wind Loads - HUD Proposed Rule . . . . . . . . . . . . 53

Table 8. Net Loads for Tributary Areas Located in Wall Interior Zone (ASCE 7-88) . . 63

\section{LIST OF FIGURES}

Figure 1. Area map showing approximate storm track and key locations $\ldots \ldots \ldots \ldots 2$

Figure 2. Isotachs of estimated maximum fastest-mile wind speeds (mph) $\ldots \ldots \ldots \ldots$

Figure 3. Estimated sustained surface wind speeds (knots) and directions at 0900 GMT . 6

Figure 4. Upper-bound estimates of fastest-mile wind speeds for selected locations . . . . 9 
Figure 5. Relationship between sustained speed and fastest-mile speed for standard wind exposure . . . . . . . . . . . . . . . . . . . . 10

Figure 6. Comparison of design wind loads for stability - net drag load . . . . . . . . 45

Figure 7. Comparison of design wind loads for stability - net uplift load . . . . . . 46

Figure 8. Comparison of design wind loads for main wind force resisting system - horizontal load . . . . . . . . . . . . . . 47

Figure 9. Comparison of design wind loads for main wind force resisting system - net uplift load . . . . . . . . . . . . . . 48

Figure 10. Comparison of design wind loads for components and cladding - walls . . . . 49

Figure 11. Comparison of design wind loads for components and cladding - roof . . . . 50

Figure 12. Basic wind zone map - HUD Proposed Rule . . . . . . . . . . . 52

Figure 13. Definition sketch of wind loading zones for components and cladding . . . . 54

Figure 14. Design wind loads for stability and main wind force resisting system - HUD Proposed Rule . . . . . . . . . . . . . . . . . . 55

Figure 15. Design wind loads for roof components and cladding - HUD Proposed Rule . 56

Figure 16. Design wind loads for wall components and cladding - HUD Proposed Rule . 57 


\section{LIST OF ACRONYMS}

ASCE 7-88

American Society of Civil Engineers - Standard 7, 1988 Ed. (Minimum Design Loads for Buildings and Other Structures)

FAA

Federal Aviation Administration

GMT

Greenwich mean time

$\mathrm{HRD} / \mathrm{AOML}$

Hurricane Research Division, Atlantic Oceanographic and Meteorological Laboratory

HUD

Department of Housing and Urban Development

LDT

Local daylight time

LLWAS

Low Level Windshear Alert System

LRFD

Load and resistance factor design

MHCSS

Manufactured Home Construction and Safety Standards

MHI

Manufactured Housing Institute

MWFRS

Main wind force resisting system

NHC

National Hurricane Center

NIST

National Institute of Standards and Technology

NOAA

National Oceanic and Atmospheric Administration

NWS

National Weather Service

OSB

Oriented strand board

SBC-91

Standard Building Code, 1991 Ed.

SFBC-88

South Florida Building Code, 1988 Ed.

USAF

United States Air Force

WERC

Wind Engineering Research Council 


\section{GLOSSARY}

Anchoring system: the combination of ties and ground anchors which provides stability for manufactured homes.

Basic wind speed: fastest-mile wind speed at $10 \mathrm{~m}(32.8 \mathrm{ft})$ above ground level in flat, open country and having an annual probability of 0.02 of being exceeded.

Cladding: the material which forms the external surface over the framing of an element of a building or structure.

Components: structural elements that are either directly loaded by the wind or receive wind loads originating at relatively close locations and that transfer those loads to the main wind force resisting system.

Cornice: horizontal molding projecting along the top of a wall.

Diagonal tie: the link between the manufactured home and ground anchor which resists sliding forces.

Dominant opening: an opening in the external surface of an enclosed building which directly influences the average internal pressure in response to external pressure at that particular opening.

Drag load: wind-induced load acting on a structure in the direction of the wind.

Eaves: that part of a roof which projects over the sidewall; the edges of the roof which extend beyond the wall.

Endwall: exterior wall oriented perpendicular to the longitudinal axis of a building.

Exposure category: classification that reflects the characteristics of ground surface irregularities upwind of a building or structure.

External pressure: the pressure acting on the exterior surfaces of a building.

Eyewall: annular region of secondary circulation marking the transition between the calm eye and the region of strongest winds.

Fastest-mile speed: the wind speed averaged over the time required for a mile-long column of air to pass a fixed point.

Gable: the triangular part of the endwall of a building with sloping roof. 
Gable end: an endwall with a gable.

Ground anchor: a device which is either driven or screwed into the ground and to which vertical and/or diagonal ties are attached.

Gust response factor: a factor that accounts for the effects of wind gusts.

Horizontal load: load acting in the horizontal direction, usually in the direction of the wind.

Hurricane: an intense tropical cyclone with sustained winds of $33 \mathrm{~m} / \mathrm{s}(74 \mathrm{mph})$ or greater.

Importance factor: a factor that accounts for the degree of hazard to human life and damage to property.

Internal pressure: the pressure acting on the interior surfaces of a building.

Isotach: line connecting points on a map of equal wind speed.

Landfall: the transition of a hurricane from over-water to over-land exposure.

Leeward wall: wall which faces away from the wind (opposite of Windward wall).

Load factor: a factor that accounts for unavoidable deviations of the actual load from the nominal value and the uncertainties in the analysis that transforms the load into a load effect.

Main wind force resisting system: an assemblage of major structural elements assigned to provide support for secondary members and cladding.

Mean recurrence interval: the number of years, on average, between events of like magnitude or intensity.

Net drag load: the resultant load acting on the exterior surfaces of a body in the direction of the wind.

Net pressure: combined effect of the internal and external pressures acting on an element.

Overhang: a projection of a roof, floor, or other horizontal part beyond the wall which carries it.

Pressure coefficient: the ratio of the average pressure acting at a point on a surface to the freestream pressure of the incident wind.

Pressure: air pressure in excess of ambient. Negative values are less than ambient, positive values exceed ambient. 
Rake: roof projection on the gable ends of a roof.

Roughness length: a theoretical quantification of the wind turbulence inducing nature of a particular type of terrain.

Secondary member: see Components.

Shape factor: see Pressure coefficient.

Sheathing: plywood, boards or similar materials that cover the outside of a building's wood frame.

Sidewall: exterior wall oriented parallel to the longitudinal axis of a building; wall oriented parallel to wind direction.

Strength limit state: a condition in which a structure or component becomes unfit for service and is judged to be unsafe.

Structural stability: resistance to being displaced by a force or by combinations of forces.

Sustained speed: the wind speed averaged over a period of 1 minute.

Tributary area: the area of a building surface contributing to the load being considered.

Uplift load: wind-induced load acting on a structure in the vertical direction.

Velocity pressure exposure coefficient: a coefficient that adjusts the velocity pressure for wind exposure category and height above ground.

Vertical tie: the link between the manufactured home and ground anchor which resists uplift loads.

Windward wall: wall which faces into the wind. 


\section{EXECUTIVE SUMMARY}

On Monday, August 24, 1992, Hurricane Andrew made landfall in south Florida between Key Biscayne and Key Largo. The maximum sustained wind speed over water is estimated to have been $64.3 \mathrm{~m} / \mathrm{s}(144 \mathrm{mph})$ which corresponds to a category 4 hurricane on the Saffir-Simpson scale. Fifteen deaths were directly attributable to Hurricane Andrew and an additional 28 deaths were indirectly related. Approximately 28,000 dwellings were destroyed or heavily damaged, and more than 120,000 people were left homeless in Dade County. In the area of highest winds, more than 5,000 manufactured homes were destroyed or were rendered uninhabitable by Hurricane Andrew. Of this number, approximately 67 percent are believed to have been HUDlabeled units. Because of the widespread damage to manufactured homes, the Department of Housing and Urban Development requested the National Institute of Standards and Technology to undertake a review of the wind load provisions of the Manufactured Home Construction and Safety Standards (MHCSS) and develop recommendations for improved wind load design criteria.

This effort has involved an assessment of the limited wind speed records that were obtained in Hurricane Andrew, the estimation of maximum surface wind speeds using results from a computer-based predictive model and from analyses, and a review of selected post-disaster reports on damage to manufactured homes and to conventional wood-framed dwellings. Also, the wind load provisions of relevant codes and standards, including the current MHCSS wind load requirements, are compared.

The highest recorded gust speed in Hurricane Andrew was $79.2 \mathrm{~m} / \mathrm{s}(177 \mathrm{mph})$ and the upperbound estimated fastest-mile speeds in the area of heaviest damage range from $54.5 \mathrm{~m} / \mathrm{s}$ (122 $\mathrm{mph}$ ) at Florida City to $64.8 \mathrm{~m} / \mathrm{s}(145 \mathrm{mph})$ at the Burger King Headquarters Building where the northern sector of the eyewall crossed the coastline. In the area where most of the manufactured home parks were located (U.S. 41 south to Country Walk and farther south to Homestead and Florida City) the estimated upper-bound fastest-mile speeds range from 42.5 to $60.3 \mathrm{~m} / \mathrm{s}$ (95 to $135 \mathrm{mph}$ ) with the highest speeds occurring at Country Walk. The corresponding gust speeds can be obtained by multiplying the fastest-mile speeds by a factor of from 1.15 to 1.20 . There were no confirmed sightings of tornadoes and subsequent aerial surveys did not produce any evidence of tornado damage.

Damage to manufactured homes ranged from loss of roofing to total destruction. In general, HUD-labeled units suffered less damage than did pre-HUD units. However, conventional residential construction adjacent to manufactured home parks performed better, in some instances significantly better, than did manufactured homes, including HUD-labeled units. Based on wind speed assessments and damage surveys described herein, it appears that HUD-labeled units began to experience damage to roof and wall coverings at fastest-mile speeds of up to $42.5 \mathrm{~m} / \mathrm{s}$ (95 $\mathrm{mph}$ ) and significant structural damage at wind speeds of from 44.7 to $53.6 \mathrm{~m} / \mathrm{s}$ (100 to 120 $\mathrm{mph}$ ). At wind speeds ranging from 53.6 to $60.3 \mathrm{~m} / \mathrm{s}$ (120 to $135 \mathrm{mph})$, there were numerous instances of HUD-labeled units suffering total destruction. 
Commonly observed failures include loss of roof membranes and blow-off of roof sheathing, failure of uplift straps at truss-to-wall connections where staple crowns pulled though the strap material, loss of cladding on endwalls and near corners where large negative (suction) pressures develop, loss of add-ons with resulting missile damage and damage to the parent unit at points of attachment, complete separation of superstructure from floor and underframe, and loss of the complete unit due to failure of tiedown straps or withdrawal of soil anchors. In almost every case some form of anchorage system had been installed. Outside the area of strongest winds there were relatively few anchor failures. Within the radius of strongest winds, the anchor

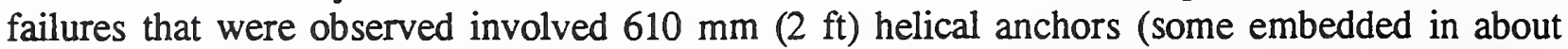
$0.08 \mathrm{~m}^{3}\left(3 \mathrm{ft}^{3}\right)$ of concrete) or rock anchors. Apparently the local soil conditions $(150-300 \mathrm{~mm}$ (6-12 inches) of sand over coral) influenced the choice of anchor type. No failures of $1.220 \mathrm{~m}$ (4 ft) helical anchors were noted. In fact, it is not clear that any anchors of this length were actually installed in the affected area.

Wind load provisions of the following codes and standards were compared by calculating the required design loads for a manufactured home of typical geometry and dimensions:
ASCE Standard 7-88 (Minimum Design Loads for Buildings and Other Structures)
Manufactured Home Construction and Safety Standards (MHCSS)
South Florida Building Code (SFBC-88)
Standard Building Code (SBC-91)
Manufactured Housing Institute proposed wind loads (MHI)

According to ASCE 7-88, the basic wind speed (fastest mile at $10 \mathrm{~m}(32.8 \mathrm{ft}$ ) in flat, open country) for the area affected by Hurricane Andrew is $49.2 \mathrm{~m} / \mathrm{s}(110 \mathrm{mph})$ and the corresponding design wind speed is $51.9 \mathrm{~m} / \mathrm{s}(116 \mathrm{mph})$. The horizontal drag load and uplift load required by the MHCSS correspond to basic wind speeds of 35.8 to $38.0 \mathrm{~m} / \mathrm{s}$ ( 80 to 85 $\mathrm{mph})$. The South Florida Building Code specifies a design wind speed of $53.6 \mathrm{~m} / \mathrm{s}(120 \mathrm{mph})$ which, in the absence of applicable gust factors, appears to be a gust speed. The drag and uplift loads required by SFBC-88 correspond to basic wind speeds of 40.7 and $43.8 \mathrm{~m} / \mathrm{s}$ ( 91 and 98 $\mathrm{mph}$ ), respectively. The Standard Building Code references the same basic wind speeds and utilizes the same source of pressure coefficients as does ASCE 7-88. However, the design wind loads are approximately 75 percent of the corresponding ASCE 7-88 loads due to a reduction factor of 0.8 applied to the pressure coefficients and disregard for the fact that the wind speed probability distributions for hurricanes and for extratropical storms are different. Although the MHI proposed wind load requirements are based on the provisions of SBC-91, simplification of the MHI loading requirements by combining pressure zones results in design loads for the main wind force resisting system (MWFRS) and for components and cladding that generally are higher than the corresponding SBC-91 loads.

Based on comparisons of design loads for a manufactured home of typical geometry and dimensions, considering the rationale for using importance factors and unreduced pressure coefficients, and in view of the fact that it is a true consensus standard, it is concluded that ASCE 7-88 should be the basis for updating the wind load requirements of the MHCSS. The 
design wind force requirements of the HUD Proposed Rule are evaluated on the basis of the ASCE wind load requirements and it is concluded that clarification and refinement of the HUD Proposed Rule are needed. Specifically, the horizontal loads specified for the design of the main wind force resisting system should be revised to make them consistent with the actual load distribution between windward and leeward walls. As currently stated, there is an inconsistency in the wind load requirements for roof perimeter zones. In addition, the HUD Proposed Rule should include a minimum requirement of $\pm 0.48 \mathrm{kPa}$ ( $\pm 10 \mathrm{psf}$ ) for the design of bottom boards. Finally, it should be made clear that the design wind loads in the Proposed Rule apply to manufactured homes with mean roof height of not more than $4.6 \mathrm{~m}(15 \mathrm{ft})$ and roof slopes in the range of 10 to 30 degrees.

This study has addressed only the load side of the design equation. In the interest of safety and economy, the prescriptive requirements of the HUD Proposed Rule should be consistent with the specified design wind loads, and the testing and analysis required to assure this consistency should be carried out. 
xvi 


\subsection{INTRODUCTION}

At approximately 0900 GMT (0500 LDT) on Monday, August 24, 1992, Hurricane Andrew made landfall on the Atlantic Coast of Florida between Key Biscayne and Key Largo. At landfall, the National Hurricane Center (NHC) has estimated the maximum sustained wind speed at $64.4 \mathrm{~m} / \mathrm{s}(144 \mathrm{mph})$ at the $10 \mathrm{~m}(32.8 \mathrm{ft})$ level over water (Rappaport 1992). This speed corresponds to a category 4 hurricane on the Saffir-Simpson scale. The hurricane followed a westerly track, passing directly over Homestead AFB, and crossed the Florida peninsula in approximately 4 hours. Andrew went on to make landfall on the south-central Louisiana coast at about 0830 GMT (0330 LDT) on August 26. In Florida, 15 deaths were directly attributable to Hurricane Andrew and 28 deaths were indirectly related. Approximately 28,000 dwellings were destroyed or heavily damaged, and more than 120,000 people were left homeless in Dade County. Damage in Florida has been estimated at more than 20 billion dollars. According to the Florida Manufactured Housing Association (1993), more than 5,000 manufactured homes in Dade County were either destroyed or rendered uninhabitable by Hurricane Andrew. Because of the heavy damage to manufactured homes, the Department of Housing and Urban Development (HUD) requested the National Institute of Standards and Technology (NIST) to undertake a review of the wind load provisions of the Manufactured Home Construction and Safety Standards (MHCSS) and develop recommendations for improved wind load design criteria.

This effort has involved the identification and documentation of surface wind speed records obtained in Hurricane Andrew during landfall, reconstruction of the surface wind field to determine probable maximum wind speeds, a review of wind damage to manufactured homes in the affected area of south Florida, an assessment of the current wind load provisions of the MHCSS and other relevant codes and standards, and the development of revised wind load criteria. In carrying out this effort, reference has been made to storm summaries, data compilations, and preliminary analyses prepared by the NHC, the Hurricane Research Division, Atlantic Oceanographic and Meteorological Laboratory (HRD/AOML), and other sources. Immediately following Hurricane Andrew, several damage survey teams carried out field studies, and selected reports on these studies are referenced in this document.

\subsection{WIND SPEEDS IN HURRICANE ANDREW}

\subsection{Recorded Wind Speeds}

The number of reliable wind speed records obtained in a landfalling hurricane usually is quite limited, and Hurricane Andrew was no exception. The reasons for this state of affairs include poorly designed anemometer masts that fail before the maximum wind speeds arrive, damage to anemometers by flying debris, failure to maintain equipment, and the use of recording systems that have no backup power. In fact, no anemometers exposed to winds in the eyewall of Andrew survived long enough or had the recording capability to register the maximum wind speeds. In view of the large number of anemometer sites in the area affected by Hurricane Andrew that had the potential for producing useful wind speed data, the limited amount of data 
actually collected is indeed appalling. In the months following Hurricane Andrew, considerable effort has been made to locate records of wind speed and/or barometric pressure from which to reconstruct the wind field over the area of heaviest damage. Records identified to date are summarized in Table 1, and the locations at which these records were obtained are indicated by ID number on Figure 1. Note that the wind speeds listed in Table 1 are "raw data" and have not been corrected to standard conditions (anemometer height of $10 \mathrm{~m}(32.8 \mathrm{ft})$ in flat, open country). There were no confirmed sightings of tornadoes in Dade County and subsequent aerial surveys did not show any evidence of tornado damage.

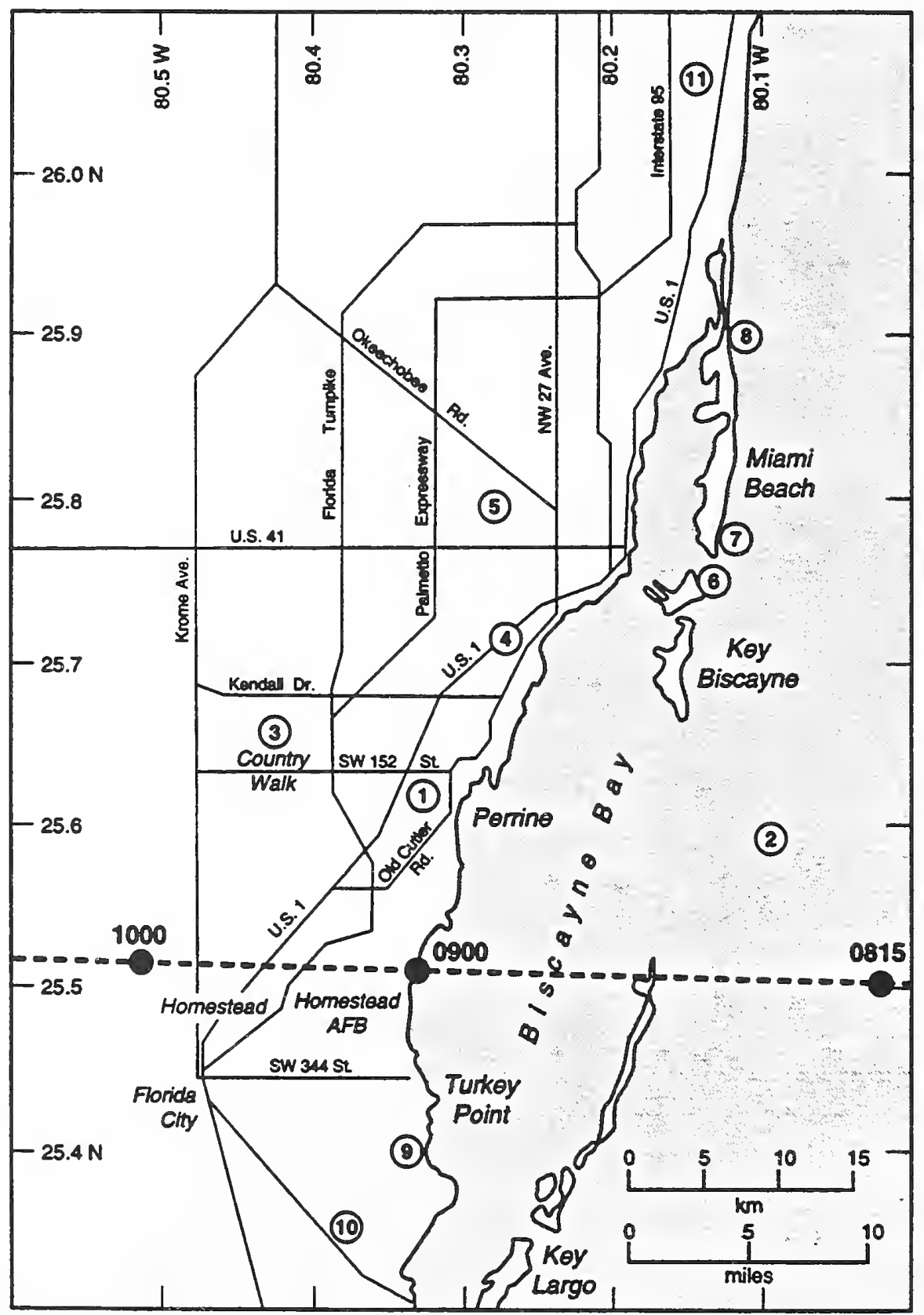

Figure 1. Area map showing approximate storm track and key locations. 


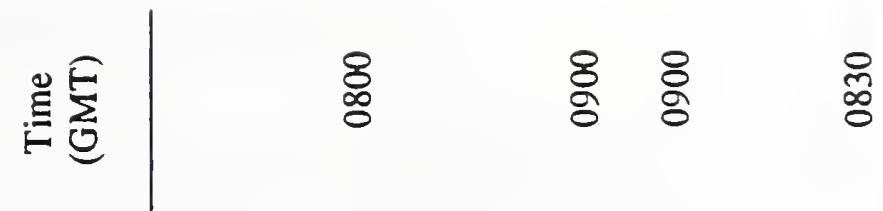

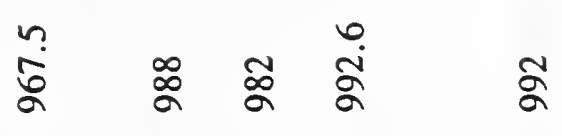

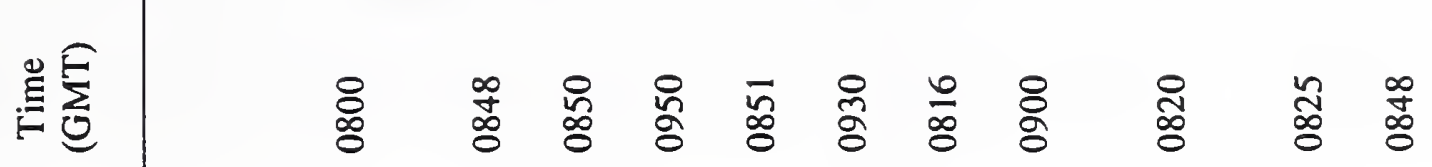

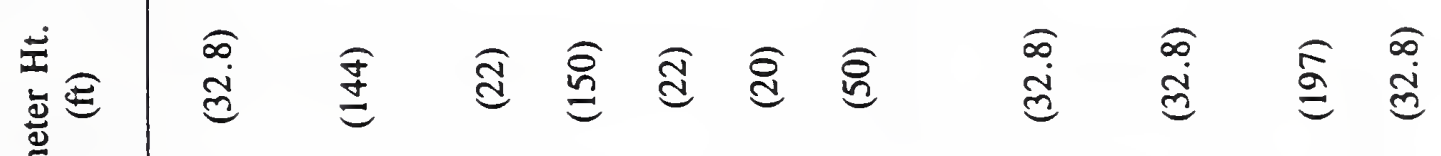

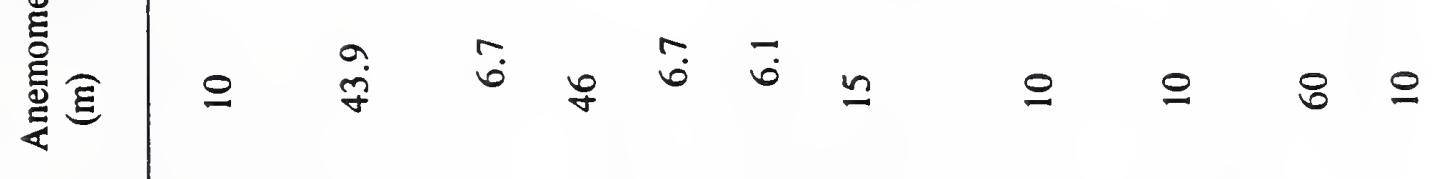

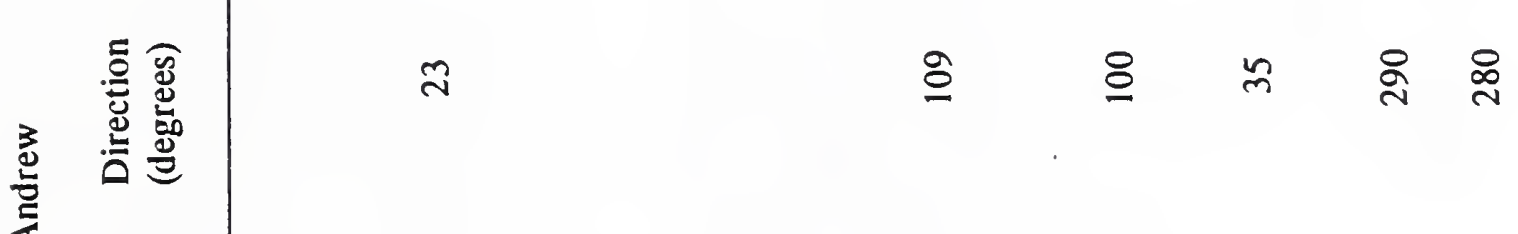

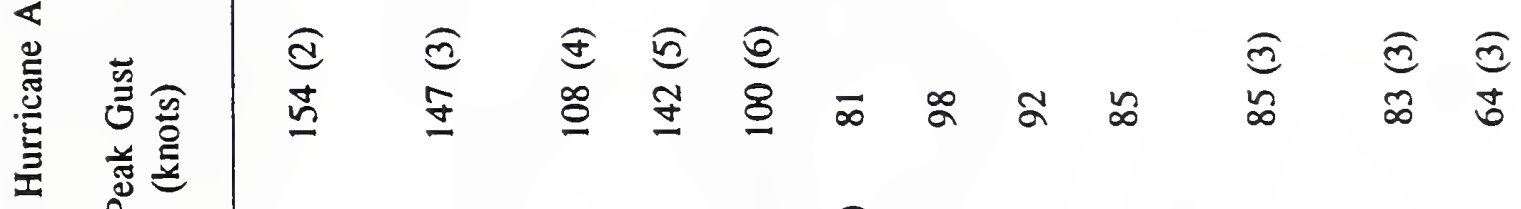

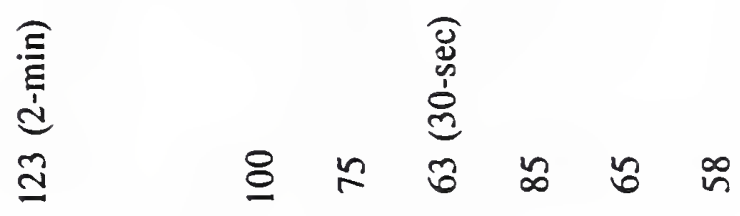

$$
\begin{aligned}
& \text { 응 } \\
& \text { 离 }
\end{aligned}
$$

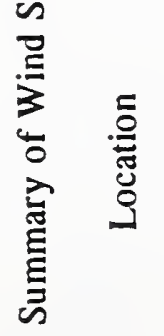

$$
\begin{aligned}
& \text { 旁立主 }
\end{aligned}
$$

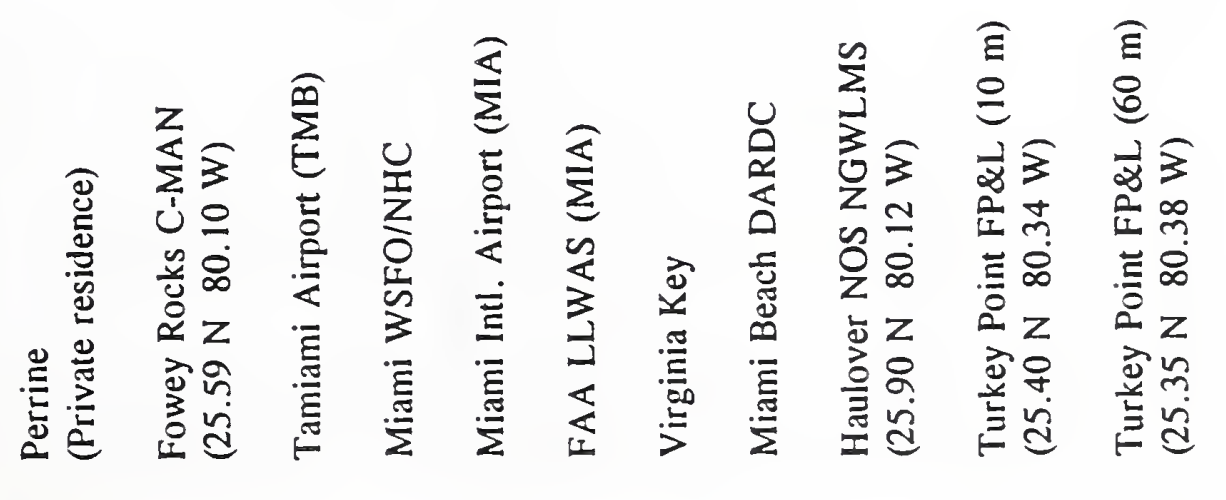




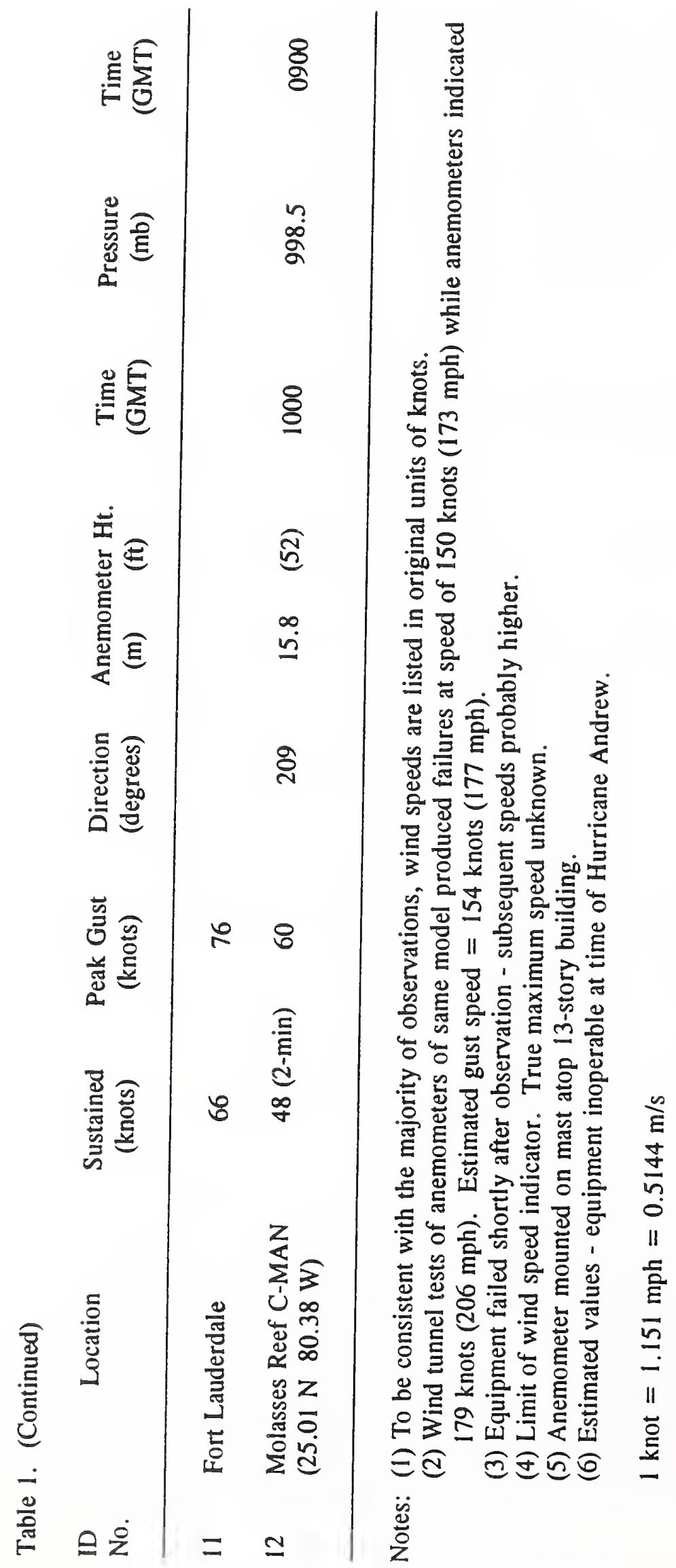




\subsection{Predictive Models}

In an attempt to reconstruct the surface wind field, Reinhold et al. (1992) have used a computerbased model that makes use of information on the storm track, barometric pressure data, and the radius of maximum winds. The transition from over-water to over-land exposure and reductions in speed as the storm moves inland are accounted for by an empirical decay model. The model generates wind speed time-histories for grid points with mesh size equal to 0.1 degree of latitude and longitude. The model was calibrated against selected records from Table 1, adjusted to standard conditions, and results of the analysis are shown in Figure 2 as fastest-mile isotachs. The values represent the estimated maximum wind speed that would have been observed under standard conditions at a given location during the passage of Andrew. An adaptation of Figure 2 can be found in ENR (Korman et al. 1993).

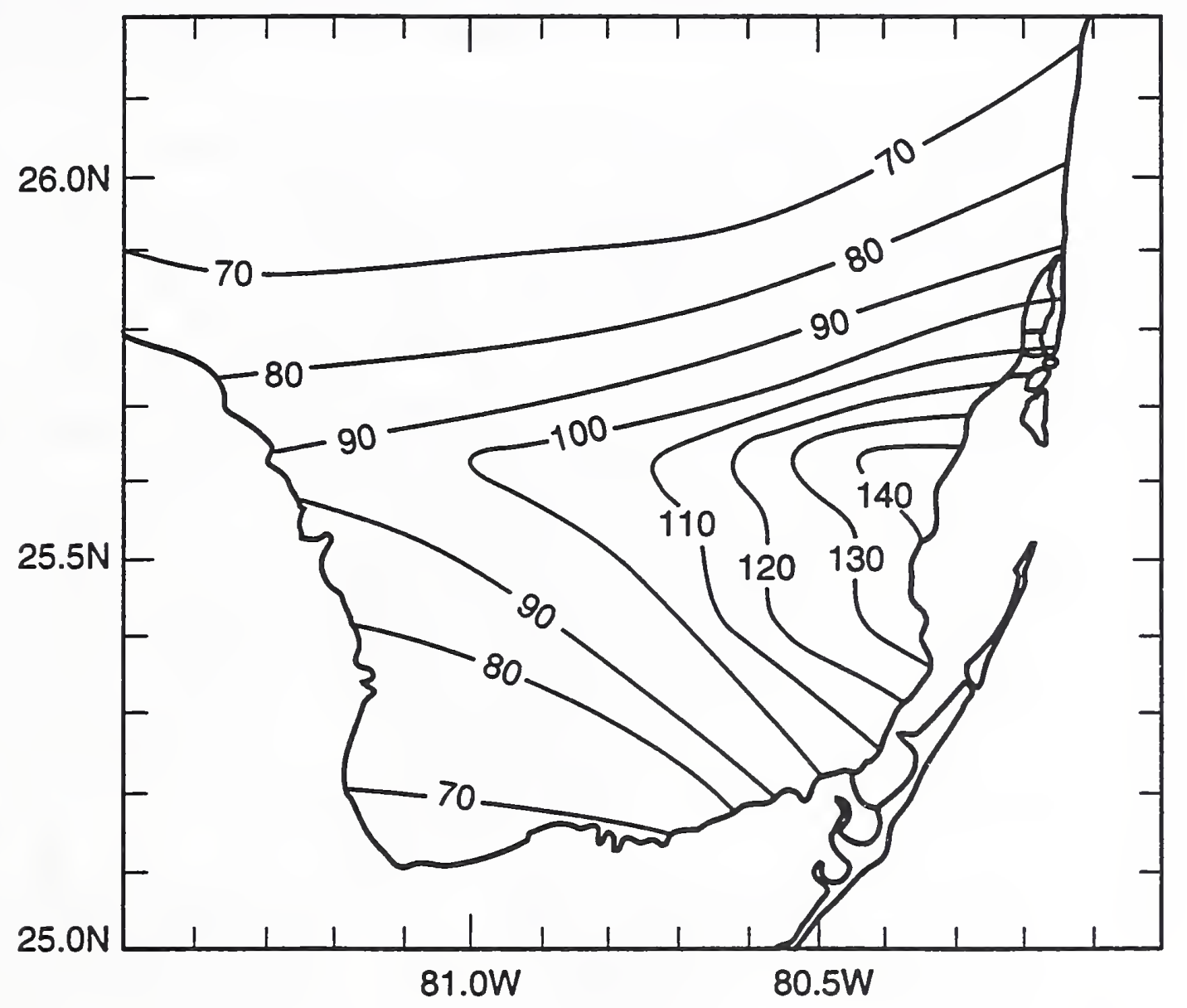

Figure 2. Isotachs of estimated maximum fastest-mile wind speeds (mph). (Reinhold et al. 1992). Note: $1 \mathrm{mph}=0.447 \mathrm{~m} / \mathrm{s}$.

The approach taken by Powell and Houston (1993) for reconstructing the surface wind field is to assemble all available wind speed data, including measurements by USAF reconnaissance aircraft prior to landfall (flight level $=3 \mathrm{~km}(10,000 \mathrm{ft})$ ), and composite these data on a storm- 
relative coordinate system over a period of approximately 5 hours. This provides a data field of sufficient density for analysis by the method of "spectral application of finite-element representation." For use in this analysis, measured surface wind speeds are adjusted to equivalent sustained speeds (1-minute average) at $10 \mathrm{~m}(32.8 \mathrm{ft}$ ) with due regard for the overwater and over-land surface roughness lengths. Flight level data are adjusted to surface conditions by empirical relationships established from flight-level/surface wind speed correlations in Andrew and in numerous other hurricanes. The result of the analysis is a "snapshot" of surface wind speeds and directions at a given time (0900 GMT in this case) as is shown in Figure 3. The isotachs (dashed lines) shown in Figure 3 represent estimated sustained speeds in knots at the standard height of $10 \mathrm{~m}(32.8 \mathrm{ft}$ ) while the streamlines (solid lines) represent wind direction. The estimated maximum sustained speed for over-water exposure is $65.3 \mathrm{~m} / \mathrm{s}$ (146 mph) near Key Biscayne while the corresponding over-land value is $60.3 \mathrm{~m} / \mathrm{s}$ (135 mph). Note that the over-water value is consistent with the maximum sustained speed of $64.4 \mathrm{~m} / \mathrm{s}$ (144 mph) noted by the National Hurricane Center in its preliminary report on Andrew (Rappaport 1992).

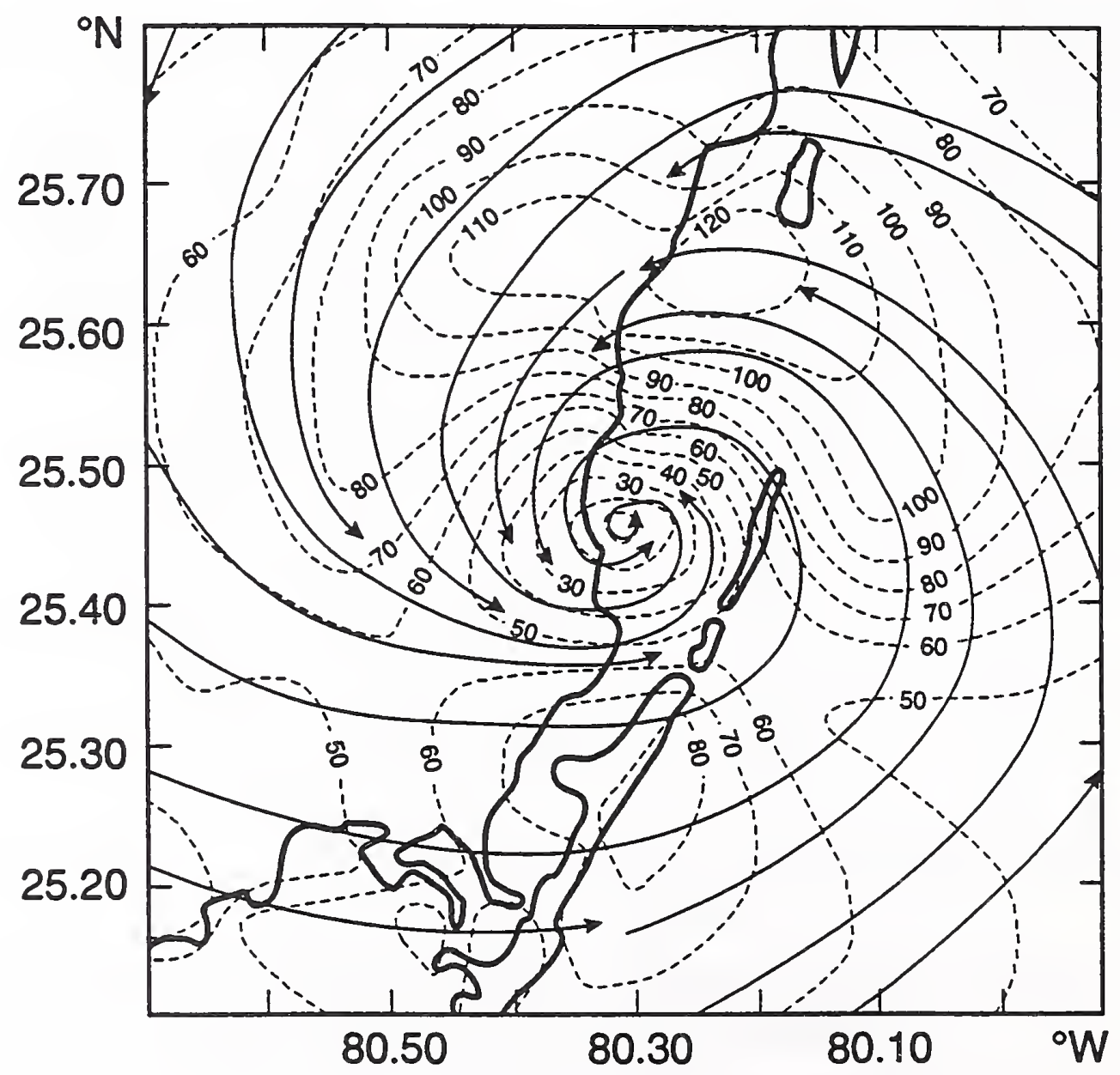

Figure 3. Estimated sustained surface wind speeds (knots) and directions at $0900 \mathrm{GMT}$. (Powell and Houston 1993). Note: $1 \mathrm{knot}=0.514 \mathrm{~m} / \mathrm{s}$. 
It must be emphasized that both analyses described above are subject to revision as additional wind speed records are identified, or as different weights are assigned to the reliability of the existing records. In particular, Powell and Houston (1993) note that the wind speeds from their analysis for the southern and southeastern sectors of the eyewall may change as the depiction of the wind exposure in those sectors is refined.

\subsection{Comparison of Predicted Speeds}

Although the analyses use different frames of reference, it is possible to make some comparisons for selected locations that experienced their maximum wind speeds at approximately 0900 GMT. This has been done in Table 2 where all speeds have been converted to equivalent fastest-mile values. Agreement between the two analyses in the northern sector of the storm is remarkably good. It is more difficult to make an evaluation for locations in the southern sector of the storm where the Powell and Houston analysis suggests maximum speeds were experienced sometime later than $0900 \mathrm{GMT}$.

Table 2. Upper-Bound Estimates of Fastest-Mile Wind Speeds for Selected Locations

Location

Estimated Fastest-Mile Speed

$\begin{array}{cc}\text { Reinhold et al. (1992) } & \text { Powell \& Houston (1993) } \\ \mathrm{m} / \mathrm{s} \quad \text { (mph) } & \mathrm{m} / \mathrm{s} \quad \text { (mph) }\end{array}$

Burger King Headquarters Building

$64.8(145)$

$65.3(146)$

Country Walk

$60.3(135)$

$54.5(122)$

Florida City

$\mathrm{m} / \mathrm{s} \quad(\mathrm{mph})$

Fort Lauderdale

Homestead AFB

$55.9(125)$

Homestead

$62.6(140)$

$67.1 \quad(150)$

Key Biscayne (south end)

$44.7 \quad(100)$

42.9

(96)

National Hurricane Center

$54.5 \quad(122)$

55.0

Turkey Point

$60.3 \quad(135)$

* Did not experience maximum speed at $0900 \mathrm{GMT}$ 
The surface wind speeds obtained from each analysis are consistent with a uniform over-land surface roughness length of $0.03 \mathrm{~m}(0.10 \mathrm{ft})$ which is undoubtedly less than the integrated effects of the actual surface conditions in the affected area. Therefore, with the possible exception of locations close to the shoreline, the resulting speeds must be viewed as upper-bound estimates. Note that the maximum wind speed originally quoted for Miami International Airport (MIA) is an estimated sustained speed of $38.4 \mathrm{~m} / \mathrm{s}$ ( $86 \mathrm{mph}$ ), and the corresponding fastest-mile speed for standard conditions is approximately $44.7 \mathrm{~m} / \mathrm{s}(100 \mathrm{mph})$. However, Low Level Windshear Alert System (LLWAS) data obtained recently from the Federal Aviation Administration (FAA) indicates a maximum 30 -second mean speed of $32.6 \mathrm{~m} / \mathrm{s}(73 \mathrm{mph})$ and a peak gust of $41.6 \mathrm{~m} / \mathrm{s}$ (93 mph) for this location. When adjusted to standard conditions, the corresponding fastest-mile wind speed is 35.8 to $38.0 \mathrm{~m} / \mathrm{s}$ ( 80 to $85 \mathrm{mph}$ ). The LLWAS data for Miami International Airport were not available when the analyses supporting Figures 2 and 3 were carried out. The fastest-mile wind speeds obtained by Reinhold et al. (1992) and listed in Table 2 for selected locations are plotted in Figure 4.

\subsection{Conversion to Fastest-Mile Speeds}

A relationship between the wind speeds averaged over one hour and the maximum speed averaged over some shorter interval within that hour has been developed by Durst (1960), and a slight modification of this relationship for hurricane winds has been proposed by Krayer and Marshall (1992). The fastest-mile speed, $U_{\mathrm{FM}}$, is averaged over the time required for a milelong column of air to pass a fixed point. Therefore, the corresponding averaging period in seconds is equal to $3600 / \mathrm{U}_{\mathrm{FM}}$. At $26.8 \mathrm{~m} / \mathrm{s}(60 \mathrm{mph})$ this averaging period is 60 seconds which is the averaging time applied to the sustained wind speed. Thus, for all other conditions being equal, the two speeds are equivalent at $26.8 \mathrm{~m} / \mathrm{s}(60 \mathrm{mph})$. Above $26.8 \mathrm{~m} / \mathrm{s}(60 \mathrm{mph})$, the averaging period for the fastest-mile speed becomes progressively less, causing the fastest-mile speed to become higher than the corresponding sustained speed. The relationship between fastest-mile speed and sustained speed is shown in Figure 5 for the speed range of 26.8 to 71.5 $\mathrm{m} / \mathrm{s}$ (60 to $160 \mathrm{mph}$ ). Over this range of wind speed the relationship is approximately linear. Although it is being phased out as a standard observation by the National Weather Service (NWS), the wind load provisions of most building codes and standards in the United States reference the fastest-mile wind speed.

\subsection{Gust Speeds}

There is considerable confusion on the part of the news media and others when quoting wind speeds. Part of the problem is a lack of understanding of the effects of averaging time, anemometer height and ground roughness on the measured wind speeds. Gust speeds and sustained speeds tend to be used interchangeably with a decided preference for the highest values. For a standard wind exposure, the gust speed averaged over 2-3 three seconds is about 1.25 times the corresponding sustained speed, or 1.15 to 1.20 times the corresponding fastestmile speed. 


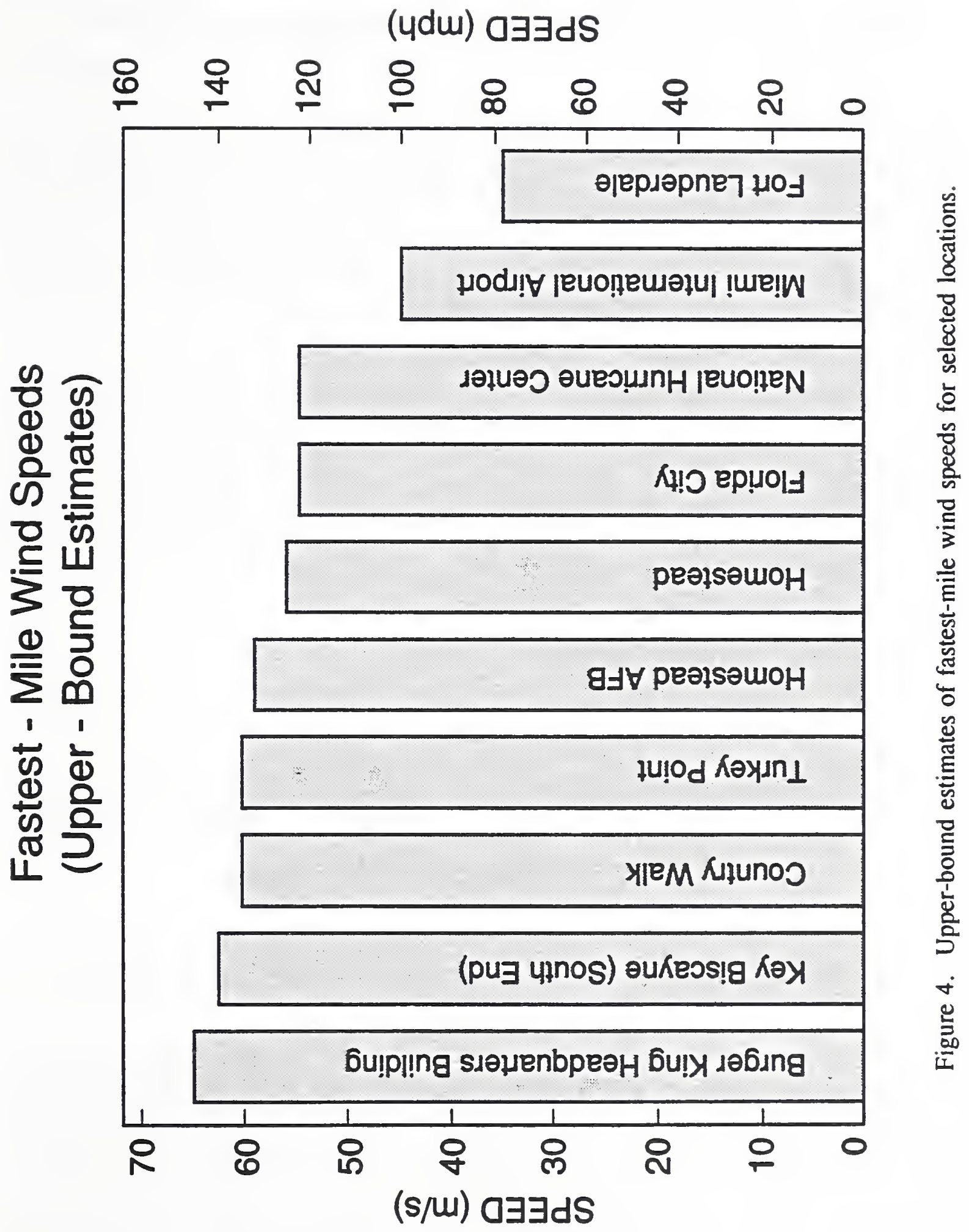




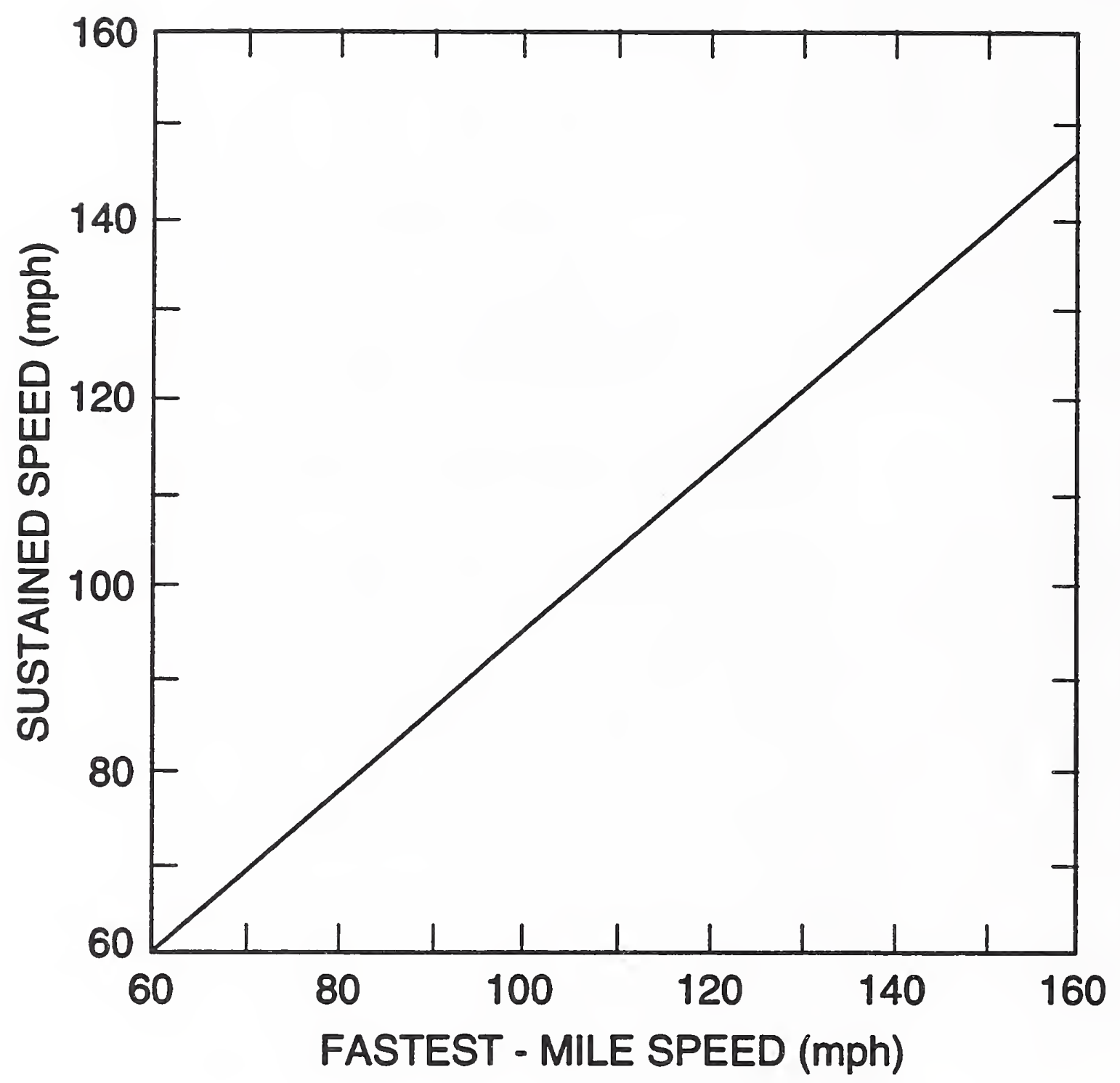

Figure 5. Relationship between sustained speed and fastest-mile speed for standard wind exposure.

Assuming a maximum over-land sustained speed of $60.3 \mathrm{~m} / \mathrm{s}(135 \mathrm{mph})$ in Hurricane Andrew, the corresponding gust speed would be about $75.5 \mathrm{~m} / \mathrm{s}(169 \mathrm{mph})$. The highest measured gust speed, corrected for anemometer error and wind exposure, was $79.1 \mathrm{~m} / \mathrm{s}(177 \mathrm{mph})$ at a private residence in Perrine (see Table 1). Powell and Houston (1993) note that gust cells associated with convective effects may combine with the large radial gradient of wind speed, particularly at the inner edge of the eyewall, to produce highly localized and intense vorticity oriented in the vertical direction. At ground level the expected effect would be streaks of locally heavier 
damage. Such streaks were observed in the Naranja Lakes area north of Homestead AFB. However, the extent of the area affected is minor when compared with the area swept by the eyewall of Andrew.

\subsection{Summary}

As with other landfalling hurricanes, the number of reliable wind speed records obtained during the passage of Hurricane Andrew was very limited. The highest recorded gust speed, corrected for anemometer error, was $79.1 \mathrm{~m} / \mathrm{s}(177 \mathrm{mph})$ at Perrine. It is possible that slightly higher gust speeds occurred near the inner side of the eyewall where conditions are favorable for the development of intense but highly localized vorticity, and post-storm observations tend to confirm this. There were no confirmed sightings of tornadoes in Dade County and subsequent aerial surveys did not show any evidence of tornado damage.

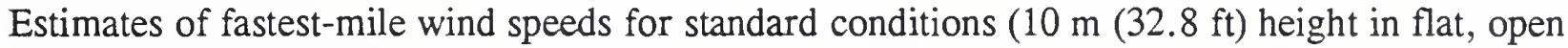
country) in the area of heaviest damage range from $54.5 \mathrm{~m} / \mathrm{s}(122 \mathrm{mph})$ at Florida City to 64.8 $\mathrm{m} / \mathrm{s}(145 \mathrm{mph})$ at the Burger King Headquarters Building near where the northern sector of the eyewall crossed the coastline. The upper-bound estimate of the fastest-mile wind speed in the Tamiami Airport/Country Walk area is $60.3 \mathrm{~m} / \mathrm{s}(135 \mathrm{mph})$. Wind speed records recently obtained from the FAA suggest fastest-mile wind speeds of 35.8 to $38.0 \mathrm{~m} / \mathrm{s}$ ( 80 to $85 \mathrm{mph}$ ) at Miami International Airport. 


\subsection{OVERVIEW OF WIND DAMAGE}

\subsection{General}

Several reports describing damage to buildings and other structures have become available in the months following Hurricane Andrew (Douglas 1992a, 1992b; FEMA 1992; Ferguson and Cardwell 1992; Keith and Rose 1992; NCSBCS 1992; Zollo 1993). One of the first such documents to be released is a report of preliminary observations and findings by the Wind Engineering Research Council (Perry et al. 1992) which addresses storm intensity, building code provisions, the performance of buildings ranging from single-family dwellings to multi-story structures, and the performance of other structures such as utility poles. An in-depth report by WERC on Hurricane Andrew is in preparation. Findings from selected field studies are summarized in this chapter. In the interest of accuracy, most of the key findings have been taken verbatim from the referenced reports.

\subsection{Conventional Wood-Framed Dwellings}

Because of the widespread damage to conventional wood-framed dwellings in Dade County, this type of structure is the focus of most post-disaster reports published to date. While the objective of this report is wind effects on manufactured homes, findings on the performance of conventional wood-framed dwellings are of interest because of the use of wood systems in both types of construction.

\subsubsection{American Plywood Association Study:}

In a report commissioned by the American Plywood Association, Keith and Rose (1992) describe failures commonly observed in structural and non-structural elements of traditional wood construction. They offer the following observations and recommendations regarding conventional wood-framed dwellings:

- Failed roofing tiles caused considerable projectile damage to adjacent buildings. It is probable that these projectiles caused many window failures which led to further structural and water damage to the affected buildings.

- In many instances, loss of roofing led to costly ceiling and interior water damage. The mechanical attachment of roof tiles and improved attachment of conventional composition shingles are needed.

- Window and door frames need to be securely fastened to surrounding framing to resist wind forces.

- Temporary protection of windows against breakage by using storm shutters of plywood or oriented strand board (OSB) panels adequately attached appears to be crucial to maintaining the integrity of the structure's envelope and thus minimize 
interior damage and increased loads due to high internal pressures.

- When attached in accordance with code-required fastening schedules, plywood and OSB roof sheathing performed equally well in resisting hurricane damage to structures.

- When staples were used to attach roof sheathing, the crowns of the staples were often found to be perpendicular to the panel edge. This practice places one or the other staple legs too close to the edge of the panel or framing, thus reducing the withdrawal capacity.

- Additional fastening of roof sheathing appears to be warranted at ends of gable roofs to resist uplift forces acting on sheathing, and additional (redundant) blocking and bracing for roof framing is suggested for gable-end walls.

- In one residential development, a non-structural rake-end roof overhang framing detail was used on the gable ends where extensive gable-end roof failures occurred. The sheathing edge-nail spacing was applied to the non-structural fascia at the roof overhang while the sheathing was only occasionally nailed to the primary structural gable-end truss.

- Connections of walls to floors (at bottom and top if applicable) and connections at corner intersections with exterior and interior walls need to be inspected more closely for conformance to code requirements.

o In cases where tiedown straps were installed properly, there was almost no damage observed due to uplift in site-built wood frame construction. Tiedown strap inadequacies, when observed, were at the roof framing level.

- It was observed that tiedown (strap-type) connections are ineffective in resisting forces normal to the wall, so that nominal code-required nailing of wall top and bottom plates to perimeter floor or roof gable-end framing must be provided.

o Wood double top plates for walls should be overlapped at ends where exterior corners or intersections with interior walls occur.

\subsubsection{American Forest \& Paper Association Study:}

In addition to describing various failure modes observed in Hurricane Andrew, Douglas (1992a, 1992b) carried out an analysis of roof sheathing fasteners, uplift connections and gable endwall loads for a structure of typical geometry and dimensions. Douglas assumed a fastest-mile wind speed of $53.6 \mathrm{~m} / \mathrm{s}(120 \mathrm{mph})$ and calculated the wind loads in accordance with the provisions of the South Florida Building Code (SFBC-88), the Standard Building Code (SBC-91), and ASCE Standard 7 (ASCE 7-88). His observations and findings are summarized as follows: 
o Failures of sliding glass doors, garage doors and picture windows formed significant openings that allowed pressurization of the building interior. This, in turn, caused increased loads on both structural and non-structural components.

o It appears that for roof perimeter sheathing attachment and uplift connections, noncompliance with existing SFBC-88 provisions was a primary cause of structural damage from Hurricane Andrew.

- Inadequate roof sheathing attachment resulted in damage ranging from the loss of a few panels to total failure of the roof system due to loss of the roof diaphragm and truss bracing provided by the sheathing.

- Significant damage was observed where fasteners were either pulled from roof truss structural members or pulled through roof sheathing by wind uplift. Problems observed included improper spacing of fasteners, use of improper nail types and sizes, and over-driving of pneumatic fasteners.

- Analysis suggests that the prescriptive requirements for sheathing fasteners were adequate to resist the SFBC-88 design wind loads at the roof perimeter. However, to resist the corresponding SBC-91 or ASCE 7-88 design wind loads, these requirements may need to be revised.

- Adequate provisions for the bracing of gable endwalls and details for uplift connections were not provided in the SFBC.

- In many newer homes, gypsum ceilings were attached to metal furring channels which, in turn, were fastened to the truss bottom chords. Not being designed as a diaphragm and having no direct attachment to the walls, this "floating ceiling" provided no bracing for the gable endwalls.

- When gable endwalls are used, the gable end should be framed with continuous studs from the floor diaphragm to the roof diaphragm. Alternatively, platformframe construction, with the endwalls attached to the bottom chord of the gable end truss, may be used provided a properly designed and installed ceiling diaphragm is used to brace the gable endwall.

- Uplift connections (or a series of connections) need to provide a continuous load path from the roof assembly to the foundation.

\subsection{Manufactured Housing}

Many of the post-disaster reports on Hurricane Andrew mention damage to manufactured housing, particularly in the Homestead-Florida City area. Three of these reports are referenced here because they address the damage in considerable detail and contain recommendations for 
improved wind resistance of manufactured homes.

\subsubsection{American Plywood Association Study:}

Keith and Rose (1992) offer the following observations and recommendations with regard to manufactured homes:

- With very few exceptions, manufactured homes in the path of Hurricane Andrew were destroyed by the resulting wind forces. Because of the almost complete destruction, it was very difficult in most cases to pinpoint the exact causes of failure.

o Non-structural siding (metal or plastic), often used in manufactured housing, is readily damaged or penetrated by flying debris during high winds. Installation over plywood or OSB panel sheathing would provide increased strength and resistance to damage.

- Lightweight steel, aluminum or plastic siding applied directly to framing does not provide sufficient strength to resist racking or uplift forces acting on walls.

o Single top plates on interior and exterior walls were observed. While this is standard practice in manufactured housing, the resulting wall is incapable of providing continuity at spliced end joints to resist wind forces normal to the wall. A double top plate with the end joints staggered and plates nailed together provides superior "beam action" in resisting such lateral forces.

- In some manufactured homes, "over the roof" tiedown straps connected to ground anchors saved the unit from complete destruction, although damage to interiors occurred when windows, doors or exterior siding were breached.

o Some examples were found where tiedown straps may have been installed too loose, allowing the unit to shift from the concrete block piers.

- Lack of adequate attachment of single or double-wide units to ground anchors was a major factor in the loss of units. The chassis of some units could be found some distance away from their original site.

- Often the tiedown straps were attached only to the chassis/floor assembly of the home. In many such instances, the floor and chassis remained in place and yet the remainder of the home was blown off and completely destroyed. This was a common occurrence in those units located in the highly publicized Homestead area. 
In one instance, a double-wide unit with wood panel siding and roof sheathing, strapped to ground anchors at several locations along the sidewalls, survived structurally intact while all units around it were completely destroyed.

\subsubsection{Manufactured Housing Institute Study:}

In a report prepared for the Manufactured Housing Institute, Ferguson and Cardwell (1992) describe the type and intensity of damage to units located throughout the storm area extending from the north side of Miami south to Florida City. Of particular interest is the fact that a concerted effort was made in the field investigation to differentiate between pre-HUD mobile homes and HUD-labeled manufactured homes. In addition, a damage index system (Vann and McDonald 1978) was used which removes much of the ambiguity as to type and intensity of observed damage. For the convenience of the reader, this damage index system is included here as Table 3. Ferguson and Cardwell also provide an assessment of wind speeds based on wind speed records that were available at the time their report was prepared (October, 1992). Park locations and brief descriptions of damage prepared by Ferguson and Cardwell are included in Table 4.

Table 3. Wind Damage Classes For Manufactured Homes (Vann and McDonald 1978)

Damage

Class

Description of Damage

$0 \quad$ No Damage or Very Minor Damage

Little or no visible damage from the outside. Slight shifting on the blocks that would suggest relevelling, but not off the blocks. Some cracked windows, but no resulting water damage.

$1 \quad$ Minor Damage

Shifting off the blocks or so that blocks press up on the floor; relevelling required. Walls, doors, etc. buckled slightly, but able to be corrected by relevelling. Minor eave and upper wall damage, with slight water damage, but roof not pulled all the way back. Minor pulling away of siding, with slight water damage. Minor missile and/or tree damage. Slight window breakage and attendant water damage.

$2 \quad$ Moderate Damage (Still Livable)

Severe shifting off blocks with some attendant floor and superstructure damage (punching, racking, etc.) Roof removed over a portion or all the home, but joists intact, walls not collapsed. Missile and/or tree damage to a section of the wall or roof, including deep dents or punctures. Serious water damage from holes in roof, walls, windows, doors or floors. 
Severe Damage (Not Livable but Repairable)

Unit rolled onto side but frame intact. Extreme shifting causing severe racking and separations in the superstructure. Roof off, joists damaged or removed, walls damaged from lack of lateral support at top. Severe tree damage, including crushing of one wall or roof section. Superstructure partially separated from underframe.

$4 \quad$ Destruction (Not Repairable)

Unit rolled onto top or rolled several times. Unit tossed or vaulted through the air. Superstructure separated from underframe or collapsed to side on the underframe. Roof off, joists removed and walls collapsed. Destruction of a major section by a falling tree.

Table 4. Manufactured Home Parks Surveyed by Ferguson and Cardwell

Park Name

Location

Description

Green Acres

\& Nelson's

(40-50 spaces)

Courtly Manor

(521 spaces)

University Lakes

(1100 spaces)

No name

Dadeland

(200 estimated)

Redlands

(90 estimated)

Isla Gold
U.S. 1 at northern

Miami city limits

Okeechobee Rd. between

Palmetto Expressway \&

Florida Turnpike

South side U.S. 41,

$1.6 \mathrm{~km}$ (1 mile) west of Florida Turnpike

U.S. 1 at SW 124th St., Kendall

13900 SW 152nd St.

SW 232nd St. at Goulds

U.S. 1 at SW 264th St., Homestead
Old park. Moderate damage.

Less than 10\% HUD-labeled.

Opened 1972. 50\% HUD-labeled.

Some Class 0 or 1 damage.

One pre-HUD Class 3 damage.

Opened 1972. 40\% HUD-labeled. 20 Class $3 \& 4$, all pre-HUD. HUD Class 0 or 1 (roofs).

Old park. No HUD units. Class 3 \& 4 damage.

Opened 1972. 50\% HUD-labeled. Class 2 to 4 damage.

Older park, mostly pre-HUD.

1 HUD Class 1, else Class

$3 \& 4$ damage.

Old park. $50 \%$ RV, $10-20 \%$ HUD. Mostly Class 4 damage. Some HUD Class 2 \& 3 damage. One HUD Class 1 damage. 
Following is a more detailed description of selected parks and estimates of fastest-mile wind speeds made by Ferguson and Cardwell.

\section{Courtly Manor:}

Located $11 \mathrm{~km}$ (6.7 miles) NW of Miami International Airport (MIA).

Fastest-mile speed slightly lower than at MIA (MIA $=38.4 \mathrm{~m} / \mathrm{s}(86 \mathrm{mph})$ ).

Only one Class 3 (pre-HUD).

Remaining units mostly Class 0 to 1 .

Damage mostly due to debris, loss of carports and attached structures.

Observed no anchor failures or shifting on blocks.

\section{University Lakes:}

Located $12 \mathrm{~km}$ ( 7.5 miles) SW of MIA.

Fastest-mile speed slightly higher than at MIA.

Approx. 20 pre-HUD units with Class 2-3 damage, 1 Class 4 damage.

HUD units fared well with some damage to roofs.

Falling trees and failure of attached structures were common cause of damage.

Observed no anchor failures or shifting on blocks.

\section{Dadeland:}

Located $22.5 \mathrm{~km}$ (14 miles) SSW of MIA, $12.5 \mathrm{~km}$ (7.8 miles) south of University Lakes.

Fastest-mile speed slightly less than 70.7-78.2 m/s (158-175 mph).

Every manufactured home received at least Class 2 damage.

Class 4 damage for pre-HUD units was typical.

$35-50 \%$ of units were HUD-labeled with damage Class 2-4.

$40-50 \%$ of units had floor remaining and superstructure gone.

$10 \%$ fitting this description may have been HUD-labeled.

Most common damage to HUD units was from debris and failure of attached structures. $10-15 \%$ of units suffered anchor system failure.

Several failures of 2 -ft helical and rock anchors, both with and without concrete collars. Approved strapping in properly installed systems performed well.

\section{Redlands:}

Located $9.5 \mathrm{~km}$ (6 miles) south of Dadeland.

Fastest-mile speed $70.7-78.2 \mathrm{~m} / \mathrm{s}(158-175 \mathrm{mph})$.

Agricultural area with open exposure.

Mostly older mobile homes.

Major damage; only one unit (HUD-labeled) remained habitable.

Only one other unit identified as HUD-labeled; Class 4 damage. 


\section{Isla Gold:}

Located $16 \mathrm{~km}$ (10 miles) south of Dadeland.

Fastest-mile speed $70.7-78.2 \mathrm{~m} / \mathrm{s}(158-175 \mathrm{mph})$.

Mixed manufactured/mobile home and RV park.

Estimated 50\% RV, 40\% pre-HUD and 10\% HUD-labeled.

One HUD-labeled unit with Class 1 damage.

Several HUD-labeled units mostly intact with Class 3 damage.

Inadequate securing of RV units and older mobile homes caused major debris damage.

Mix of debris made identification of many units impossible.

Observations and findings by Ferguson and Cardwell are summarized as follows:

- HUD-labeled manufactured homes fared better than pre-HUD mobile homes both inside and outside the major storm area.

- Conventional residential construction near the manufactured home communities surveyed generally fared significantly better than manufactured homes (including HUD-labeled units).

o The first mode of failure for both manufactured homes and conventional residential construction (absent missile damage or failure of attached add-ons) was roof covering.

- Panels on the corners of metal sided units tended to fail before siding located away from the corners. This is consistent with higher pressure coefficients in the Standard Building Code and in ASCE 7-88.

o Add-ons (carports, awnings, etc.) were a major contributor to damage. Where attached to the exterior of manufactured homes, failure of add-ons took siding and/or roof material with them which then led to progressive failure of the primary structure.

- Some cases were observed (inside the major storm area) where units had structural failures at each end but shear walls located 3.0-3.7 m (10-12 ft) inboard halted further failure.

o Anchor systems were universally present and these systems generally performed well with no observed failures outside the major storm area.

- Inside the major storm area where wind speeds were above design condition, there were some anchoring failures but the number of structural failures where the manufactured home failed at the floor or above far outnumbered the anchor system failures. 
o Two-foot helical and rock anchors, which are not in compliance with the Florida DMV Code, failed frequently inside the major storm area. These anchors were commonly used because local soil conditions (150-300 mm (6-12 inches)) of sand

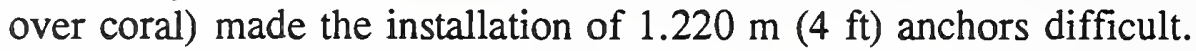

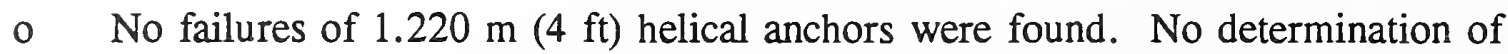
the type of anchors which did not fail was made; consequently the failure rates

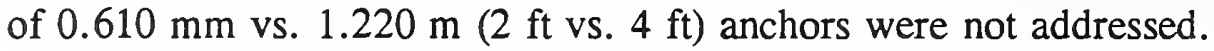

\section{COMMENT:}

The observation that "... there were some anchoring failures but the number of structural failures where the manufactured home failed at the floor or above far outnumbered the anchor system failures." deserves comment. In view of the generally good performance of anchoring systems outside the major storm area, the reader might reach a similar conclusion for units located within the major storm area. Perhaps a more accurate observation would be that, generally, the load capacity of the anchor system exceeded that of the manufactured home superstructure. Without knowing the magnitudes of the drag and uplift loads actually resisted by the superstructure, and thus the anchor system, it is not possible to assess anchor system performance, at least in absolute terms. If superstructure failures had not occurred, the number of anchor system failures might well have been greater.

The wind speeds presented by Ferguson and Cardwell are questionable. For example, it is stated that sustained wind speeds reported by the National Weather Service (NWS) correspond to a 2-minute average and that these speeds are corrected to a standard height of $10 \mathrm{~m}(32.8 \mathrm{ft})$. In fact, the sustained speeds reported by the National Hurricane Center (NHC) in its preliminary report on Hurricane Andrew (Rappaport 1992) are 1-minute averages that have not been corrected for anemometer height. Exceptions to the 1-minute average are wind speeds reported for the C-MAN stations, the NOAA data buoys, and the FAA LLWAS. C-MAN stations report a 2-minute mean at the beginning of each hour and 10-minute means at other times while NOAA data buoys report 8-minute mean speeds. FAA LLWAS reports a 30 -second running mean each 10 seconds. The maximum sustained speed in Andrew has been estimated by NHC to be 64.3 $\mathrm{m} / \mathrm{s}$ (144 mph) just before landfall. The corresponding fastest-mile speed would be approximately $69.3 \mathrm{~m} / \mathrm{s}(155 \mathrm{mph})$. However, this is for an over-water exposure and the corresponding wind speeds over land would be less than these values. As has been noted in Chapter 2, the upper-bound estimates of fastest-mile speeds for inland areas ranged from 54.5 $\mathrm{m} / \mathrm{s}(122 \mathrm{mph})$ at Florida City to $60.3 \mathrm{~m} / \mathrm{s}(135 \mathrm{mph})$ at Country Walk. To the north, fastestmile speeds ranged from 35.8 to $38.0 \mathrm{~m} / \mathrm{s}$ ( 80 to $85 \mathrm{mph}$ ) at Miami International Airport (MIA) to $34.9 \mathrm{~m} / \mathrm{s}(78 \mathrm{mph})$ at Fort Lauderdale. In the area along U.S. 41 to the southwest of MIA, the fastest-mile speeds probably did not exceed $42.5 \mathrm{~m} / \mathrm{s}(95 \mathrm{mph})$.

\subsubsection{NCSBCS Study:}

Under contract with the Department of Housing and Urban Development, the National 
Conference of States on Building Codes and Standards (NCSBCS) organized a team of experts to study and report on damage to manufactured housing in Florida and Louisiana following Hurricane Andrew (NCSBCS 1992). The field investigation of damage in south Florida was conducted during the week of September 7, 1992, and seven manufactured home parks were examined. Later that same week the team visited eight manufactured home parks in Louisiana. In south Florida, two of the parks visited by the NCSBCS team were located in the HomesteadFlorida City area, one (Dadeland) was located adjacent to the Country Walk development on SW 152 St., and the remaining four parks (including University Park) were located farther north along U.S. 41 (Tamiami Trail). Note: In this report, manufactured homes and mobile homes appear to be referred to collectively as manufactured homes. However, an attempt is made to differentiate between pre-HUD and HUD-labeled construction. The team's findings are summarized in the following paragraphs.

General:

- Most of the manufactured homes that the team saw in the Homestead-Florida City area had been destroyed. More than half of the manufactured homes in this area were constructed before June, 1976, when the HUD Standards went into effect.

- At the Dadeland Park most of the manufactured homes that the team observed had received extensive damage or had been destroyed. Of the estimated 200 manufactured homes in this park that were destroyed, approximately half were built before June, 1976.

- Many of the homes in the four parks located along U.S. 41 were not destroyed; of those that were, most had been built before June, 1976.

- University Park (located along U.S. 41) contained approximately 1,150 units and about 20 of these, located randomly throughout the park, sustained major damage. Most of the homes in this park that were severely damaged were pre-HUD construction. Damage to other units was limited to exterior coverings; for example, siding and shingles were blown from the homes. Damage to site-built homes around University Park appeared to be limited to roof coverings. Note: This park appears to be the same park Ferguson and Cardwell (1992) refer to as University Lakes.

Roofing Systems:

o For most of the units examined, shingles were attached to the roof sheathing with staples. The shingles were pulled away, leaving the staples embedded in the sheathing, much the same as what happened with conventional housing.

- Plywood sheathing attached by staples had been blown off due to staples being withdrawn from the roof trusses. In some instances complete rows of staples had 
missed the roof trusses and in other instances the staples were partially withdrawn with the sheathing still in place.

- Failures of metal roof coverings generally started with failure of fasteners whose function was to attach the metal roof covering to the sidewalls. Progression of the failures involved separation of seams between adjacent sheets.

Walls:

- Typical failures of siding involved the withdrawal of fasteners from the wall studs or the separation of interlocking seams (both horizontal and vertical) of metal siding and vinyl lap siding. Since wall sheathing is not generally used, failure of the siding directly exposed the wall cavity and the interior wall covering to the elements.

o Corners and endwalls were particularly prone to wind damage (removal of siding), even for units that suffered only minor damage overall. Siding was missing from endwalls in more cases than it was missing from sidewalls.

\section{Structural Connections:}

o In units experiencing separation of the roof from the sidewalls, the team observed many failures of uplift straps. In most cases this involved the crowns of the staples pulling through the strap material and subsequent failure of the connection.

- In most manufactured homes examined, the floor joist to chassis connections remained intact. Observed failures were limited to systems constructed with floor joists oriented parallel to the main chassis beams. It is noted that the majority of current designs employ floor joists oriented perpendicular to the main chassis beams.

Bottom Board:

- This non-structural element supports the insulation in the floor cavity. Observations suggest that bottom boards are likely to fail when skirting is either not installed or is removed by the wind.

Anchoring Systems:

o The team noted that virtually all of the units inspected in Florida had been anchored while many of the units in Louisiana had no anchoring system.

- Many of the units investigated did not have the number of diagonal ties specified by the home manufacturer's installation requirements or had over-the-roof straps 
which were not always aligned with the wall studs. In some cases the diagonal ties were attached only to the bottom flanges of the chassis longitudinal beams.

In Florida there were a number of instances where failed anchors had been embedded approximately two feet while other failures involved anchors that had been embedded in about $0.08 \mathrm{~m}^{3}\left(3 \mathrm{ft}^{3}\right)$ of concrete.

\section{COMMENT:}

The observations reported by the NCSBCS investigative team are in general agreement with those reported by other investigators. In their report the NCSBCS team makes the statement that "All of the manufactured home parks that the investigative team visited were determined to be in Exposure B areas." ASCE 7-88 defines this exposure category as follows:

Exposure B. Urban and suburban areas, wooded areas, or other terrain with numerous closely spaced obstructions having the size of single-family dwellings or larger. Use of this exposure category shall be limited to those areas for which terrain representative of Exposure B prevails in the upwind direction for a distance of at least $460 \mathrm{~m}(1500 \mathrm{ft})$ or 10 times the height of the building or structure, whichever is greater.

The name and exact location of the parks visited by the NCSBCS team are not known in each case. However, it is clear from aerial photographs that Dadeland Park does not meet the requirements of Exposure Category B. In fact, the upwind terrain for the direction of the strongest winds (northeast) is over cultivated farm land and this qualifies the site as Exposure Category C. As is noted in Section 4.2 of this report, the difference in the calculated drag and uplift loads for these two exposure categories is approximately a factor of $\mathrm{x} 2$.

\subsubsection{Florida Manufactured Housing Association Study:}

A post-storm survey carried out by the Florida Manufactured Housing Association (1993) focused on manufactured home parks located within the area of highest winds. Approximately, this survey included parks located south of Kendall Drive. Park operators in the survey area were queried as to the number of manufactured homes that were either destroyed or otherwise uninhabitable and of that total, the number that were pre-HUD and post-HUD units. Recreational vehicles, campers, etc. were excluded from the study. Results of the survey are given in Table 5.

According to the damage classification criteria given in Table 3, the units counted in Table 5 would have experienced damage of class 3 or 4 . However, there appears to have been no systematic assessment of damage according to type or intensity. Had this been done, it is possible that some damage would have been assigned to other classes. Nevertheless, Table 5 provides an estimate of the number of manufactured homes in the area south of Kendall Drive that were either destroyed or experienced significant damage. Also, Table 5 indicates that of 
the more than 5,000 units included in the count, approximately two-thirds of them were postHUD construction.

Table 5. Manufactured Homes in Dade County Destroyed or Rendered Uninhabitable (Florida Manufactured Housing Association, Inc. 1993)

Park Name

Total Number
of Units

Pre-HUD*
Units

Post-HUD*

Units

Isla Gold

Four Seasons

Sunrise Village

Coral Roc

Royal Palm

Dixie Trailer Park

Royal Colonial

Homestead Trailer Park

Pine Lake

Princetonian

Park View Trailer Park

Pine Isle

Dadeland

Silver Palm

DeSoto

Quail Roost

Oasis

Cove

Aquarius

Leisure

Redlands

Goldcoaster

Subtotal

Subdivisions

American Village

Gateway \& Gateway West

Grand Total
28

205

301

200

130

60

284

47

597

280

60

317

332

112

211

389

29

25

185

275

80

547

4694

700

\section{8}

51

60

120

127

59

71

42

119

98

60

63

116

90

74

136

29

21

74

55

76

82

1633

140

560

Percent

1773

3621

32.9

67.1

* Numbers based on percentages supplied by park operators 


\subsection{Summary:}

Based on the post-disaster studies reviewed in this chapter and the wind speed assessments described in Chapter 2, structural damage to conventional wood-framed dwellings and to manufactured homes is summarized here.

\subsubsection{Conventional Wood-Framed Dwellings:}

Roofing systems suffered heavy damage over a wide area along the storm track, pointing up the need to develop improved methods of attaching conventional composition shingles to roof sheathing. The failure of roof tile, which were not mechanically fastened, created a source of missiles that caused window breakage in adjacent structures. Window breakage, garage door failures, and inadequate fastening of window and door frames resulted in the pressurization of building interiors and additional structural damage as well as water damage. Much of this damage could have been avoided with the installation of temporary storm shutters.

The loss of roof sheathing, particularly perimeter sheathing at gable ends, resulted in the loss of diaphragm action of the roof structure and progressive failure of roof trusses. Much of this damage is directly attributable to improper installation of sheathing fasteners and disregard for the fastener schedules required by the South Florida Building Code. Analysis suggests that the prescriptive requirements of SFBC-88 for sheathing attachment are consistent with the prescribed wind loads, but that these same prescriptive requirements would not be adequate for the design wind loads required by the Standard Building Code or by ASCE 7-88. Where they were properly installed, tiedown straps were effective in transferring uplift loads from roof trusses to walls.

Many instances of gable-end wall failures were observed. In large part, these failures were due to inadequate connections and the lack of lateral support or bracing that should have been provided by ceilings designed to act as diaphragms. Other exterior wall failures resulted from inadequate nailing at corner connections and improper or inadequate overlapping of double top plates at exterior corners and at intersections with interior walls.

\subsubsection{Manufactured Housing:}

In Dade County, more than 5,000 manufactured homes were destroyed or were rendered uninhabitable by Hurricane Andrew. Of this number, approximately 67 percent are believed to have been HUD-labeled units.

As with conventional residential construction, the failure of roofing systems was widespread. Failures of metal roof coverings initiated with the loss of attachment at the sidewalls, and instances were noted where entire rows of sheathing fasteners had missed the roof truss. Failures of truss-to-wall connections were observed in which staple crowns had pulled through the uplift strap. 
The failure of wall panels and fasteners, particularly on metal clad units, was a common occurrence on endwalls and in areas adjacent to corners where flow separation leads to intense negative (suction) pressures. Interlocking seams in metal and vinyl lap siding were prone to separation and opening when these materials were installed without the support of wall sheathing. These failures exposed the wall cavity and interior wall covering to the action of wind and water.

The failure of add-ons such as carports and awnings was a major source of windborne debris in manufactured home parks. Where they were attached to manufactured homes, these add-ons caused damage to siding and roofing which often led to progressive failure of the primary structure. Although some instances were noted where endwall failures of manufactured home superstructures were arrested by interior shear walls, there were many instances in which the entire superstructure was cleanly removed from the floor system.

Almost all of the units inspected in Florida had some anchoring system installed and, in general, these systems performed well outside the area of highest winds. Many units did not have the number of diagonal ties specified by the home manufacturer's installation requirements or had over-the-roof straps which were not always aligned with the wall studs. In some cases the diagonal ties were attached only to the bottom flanges of the chassis longitudinal beams. For areas near to or within the eyewall, anchoring failures were observed and these failures involved $610 \mathrm{~mm}\left(2 \mathrm{ft}\right.$ ) helical anchors (some embedded in about $0.08 \mathrm{~m}^{3}\left(3 \mathrm{ft}^{3}\right)$ of concrete) or rock anchors. Apparently the local soil conditions (150-300 mm (6-12 inches) of sand over coral) influenced the choice of anchor type. No failures of $1.220 \mathrm{~m}(4 \mathrm{ft})$ helical anchors were noted. In fact, it is not clear that any anchors of this length were actually installed in the affected area.

In general, HUD-labeled units suffered less damage than did pre-HUD units. However, conventional residential construction located near manufactured home parks performed significantly better than did manufactured homes, including HUD-labeled units. Based on the wind speed records obtained during the passage of Hurricane Andrew and on subsequent analyses described in Chapter 2, the fastest-mile speeds at manufactured home parks located along U.S. 41 probably did not exceed $42.5 \mathrm{~m} / \mathrm{s}(95 \mathrm{mph})$. At Florida City, the upper-bound estimate is $54.5 \mathrm{~m} / \mathrm{s}$ (122 mph) while at the Dadeland manufactured home park (SW $152 \mathrm{St}$.), the corresponding value is $60.3 \mathrm{~m} / \mathrm{s}(135 \mathrm{mph})$.

Based on the wind speed assessments described in Chapter 2 and on the damage surveys summarized herein, it appears that HUD-labeled units began to experience damage to roof and wall coverings at fastest-mile wind speeds of about $42.5 \mathrm{~m} / \mathrm{s}(95 \mathrm{mph})$ and significant structural damage at speeds of from 44.7 to $53.6 \mathrm{~m} / \mathrm{s}$ (100 to $120 \mathrm{mph}$ ). At wind speeds ranging from 53.6 to $60.3 \mathrm{~m} / \mathrm{s}$ (120 to $135 \mathrm{mph})$, there were numerous instances of HUD-labeled units suffering total destruction. 


\subsection{COMPARISON OF DESIGN WIND LOADS}

\subsection{General}

In this chapter the wind load provisions of selected codes and standards are summarized and similarities and important differences are noted. To provide quantitative comparisons of the provisions, design wind loads are calculated for a manufactured home of typical geometry and dimensions located in a hurricane-prone coastal region.

\subsection{ASCE Standard 7-88 (Minimum Design Loads for Buildings and Other Structures)}

This design load standard, formerly designated as ANSI A58.1-1982, was reissued in 1988 with minor revisions as ASCE 7-88. The next revision of the wind load provisions and other provisions of the standard is scheduled for 1995. The essential features of the wind load provisions are a map showing basic wind speeds (fastest-mile speeds associated with a 0.02 annual probability of exceedance), a set of importance factors that account for the function or category of the building or structure and the risk of an overload condition, tables of velocity pressure exposure coefficients and gust response factors to account for the wind exposure category (A,B,C or D) and height above ground, and tables of pressure and force coefficients by which to convert velocity pressure to effective surface pressures or loads.

The design wind speed is obtained by multiplying the basic wind speed by the appropriate importance factor. The net effect is to change the annual probability of the design wind speed being exceeded to either 0.01 or 0.04 . Because the probability distribution of extreme speeds in hurricanes differs from that of extreme speeds in extratropical storms, the importance factors for structures located in hurricane-prone coastal regions are slightly larger than those for structures located sufficiently far inland. In fact, the influence of hurricanes on the distribution of extremes is assumed to reduce to zero for sites located a distance of $160 \mathrm{~km}$ (100 miles) or more from the coastline. For distances of less than $160 \mathrm{~km}$ (100 miles), the reduction of the importance factor is assumed to be linear with distance from the coastline.

The ASCE Standard recognizes four wind exposure categories which can be described briefly as follows:
A - Centers of large cities
B - Urban and suburban areas
C - Open terrain with scattered obstructions
D - Flat, unobstructed areas exposed to wind approaching over large bodies of water

Because some distance is required for the mean velocity profile to adjust to changes in ground roughness, each of the wind exposure categories includes some minimum upwind distance over 
which that roughness must obtain in order for a site to qualify for a particular exposure category. Because the intensity of turbulence increases with decreasing distance above ground, there are some special requirements for the selection of exposure categories when designing components and cladding. Those requirements are as follows:

o For buildings with height less than or equal to $18.3 \mathrm{~m}(60 \mathrm{ft})$, components and cladding are designed on the basis of exposure category $\mathrm{C}$, regardless of the actual exposure category for the building site.

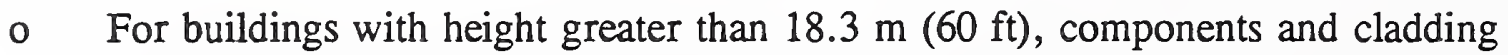
for buildings sited in exposure category $\mathrm{A}$ are designed on the basis of exposure category B.

Because of the minimum upwind distances specified for the various exposure categories, it is prudent to select the next smoother exposure category when there is any question as to the prevailing upwind roughness. In particular, caution should be used with exposure category B when smoother terrain is located nearby. For all other conditions being equal, the calculated wind loads for exposure categories $\mathrm{B}$ and $\mathrm{C}$ differ by a factor of approximately $\mathrm{x} 2$.

For the design of main wind force resisting systems (MWFRS), pressure or force coefficients are used in conjunction with gust response factors evaluated at the height of the structure. The coefficients are directionally dependent; i.e., dependent upon the ratio of the along-wind building dimension to the across-wind dimension. The effects of internal pressure on the MWFRS are included in the load calculations.

For the design of components and cladding, the exterior surfaces of the building are zoned and the value of the pressure coefficient is dependent upon the zone designation and the extent of the area over which the pressure is assumed to act. Unlike the MWFRS pressure or force coefficients, pressure coefficients for the design of components and cladding are provided as the product of a gust response factor and pressure coefficient, $\mathrm{GC}_{\mathrm{p}}$. The resulting pressures are envelope values; i.e., the calculated external pressures represent the worst case for all possible wind directions. It must be recognized that since these pressures are envelope values, the maximum (or minimum) pressures do not act on all exterior surfaces at the same time or for the same wind direction. In the determination of wind loads acting on components and cladding, ASCE 7-88 distinguishes between buildings with height less than or equal to $18.3 \mathrm{~m}(60 \mathrm{ft})$ and buildings taller than $18.3 \mathrm{~m}(60 \mathrm{ft})$.

Internal pressures are dependent upon the size and distribution of openings in the building envelope and, as with the external pressure coefficients for components and cladding, are presented as a product, $\mathrm{GC}_{\mathrm{PI}}$, of a gust response factor and a pressure coefficient. The net or resultant pressure acting on a component or cladding element is the algebraic sum of the internal and external pressures acting on that component or element. 


\subsection{Manufactured Home Construction \& Safety Standards (MHCSS)}

This standard (24 CFR, Chapter XX, Part 3280) is administered by the Department of Housing and Urban Development and covers all equipment and installations in the design, construction, fire safety, plumbing, heat-producing and electrical systems of manufactured homes which are designed to be used as dwelling units.

The MHCSS wind load provisions address two wind regions or zones; a standard wind (Zone 1) and a hurricane-resistive (Zone 2). Approximately, the boundary between these two zones corresponds to the $35.8 \mathrm{~m} / \mathrm{s}(80 \mathrm{mph})$ isotach located inland from the Atlantic and Gulf Coasts as shown on the wind speed map contained in ASCE 7-88. For Zone 1, the manufactured home and each wind resisting part or portion is to be designed for horizontal wind loads of not less than $0.72 \mathrm{kPa}$ (15 psf) and a net uplift load of not less than $0.43 \mathrm{kPa}(9 \mathrm{psf})$. The corresponding requirements for Zone 2 are $1.20 \mathrm{kPa}(25 \mathrm{psf})$ and $0.72 \mathrm{kPa}(15 \mathrm{psf})$, respectively. For the design of eaves and cornices, the net uplift pressures cited above are to be multiplied by a factor of 2.5 .

For the design of support and anchoring systems to resist lateral movement and overturning, the horizontal and net uplift loads specified for Zones 1 and 2 are increased by 50 percent. Basic allowable stresses for materials used in the support and anchoring systems are not to be increased for wind loading.

The MHCSS wind load provisions do not address internal pressures explicitly, nor do they address the effects of ground roughness or terrain features on wind speed. For coastal exposures, or where climatological data suggest design speeds of $55.9 \mathrm{~m} / \mathrm{s}(125 \mathrm{mph})$ or more, the Department can require more stringent design requirements than those described above.

\subsection{South Florida Building Code (SFBC-88)}

SFBC-88 does not reference the ASCE 7-88 wind speed map, but requires a design wind speed of $53.6(120 \mathrm{mph})$. The code does not indicate whether this is a gust speed or some timeaveraged speed. For buildings located in the coastal building zone (defined as being within 460 $\mathrm{m}(1,500 \mathrm{ft})$ of the water line), the code requires design for "forces associated with a onehundred year storm event." However, no specific wind speed is provided or suggested for such an event.

It appears that the design wind speed of $53.6 \mathrm{~m} / \mathrm{s}(120 \mathrm{mph})$ referenced by SFBC- 88 is a gust speed. In fact, the SFBC-88 drag loads for typical building geometries evaluated at a height of $9.1 \mathrm{~m}$ (30 feet) are consistent with the ASCE 7-88 drag loads for a basic wind speed of $46.0 \mathrm{~m} / \mathrm{s}$ (103 mph). According to ASCE 7-88, the basic wind speed for the area south of Miami affected by Hurricane Andrew is $49.2 \mathrm{~m} / \mathrm{s}(110 \mathrm{mph})$, and the design speed is $(1.05)(49.2)=51.9 \mathrm{~m} / \mathrm{s}$ $(116 \mathrm{mph})$. Therefore, the annual probability of exceeding the design wind speed specified by SFBC- 88 is somewhat greater than 0.02 (mean recurrence interval of less than 50 years). 
Adjustments to the velocity pressure for height above ground are accomplished by use of a table of velocity pressures or by an equation relating velocity pressure to height. The form of the equation for velocity pressure suggests a terrain roughness equivalent to exposure category $C$ in ASCE 7-88.

Shape factors (equivalent to pressure coefficients in ASCE 7-88 for the design of MWFRS) for the stability of buildings or structures with a mean roof height of less than $18.3 \mathrm{~m}(60 \mathrm{ft})$ are the same for the coastal building zone and for areas outside of this zone. But the shape factors for components and cladding are different for the two zones. No gust response factors are provided in SFBC-88. Presumably these factors are combined with the shape factors for components and cladding, but they clearly are not included in the shape factors for the MWFRS since there is a one-to-one correspondence with the factors listed in ASCE 7-88.

As is the case for the MHCSS, the South Florida Building Code does not address internal pressures explicitly. If they are accounted for, the corresponding pressure coefficients have been combined with those for external surfaces.

The reader should note that there is not necessarily a direct correspondence between the specified design wind loads and the prescriptive requirements of SFBC- 88 .

\subsection{Standard Building Code (SBC-91)}

The wind load provisions of SBC-91 are similar to those of ASCE 7-88 in that the same map of basic wind speeds is referenced and pressure coefficients for components and cladding are expressed as the product, $\mathrm{GC}_{\mathrm{P}}$, of a gust response factor and a pressure coefficient. In fact, the primary source of the pressure coefficients for SBC-91 and ASCE 7-88 is the same. As with ASCE 7-88, a distinction is made between buildings with heights equal to or less than $18.3 \mathrm{~m}$ $(60 \mathrm{ft})$ and buildings with heights greater than $18.3 \mathrm{~m}(60 \mathrm{ft})$.

There are, however, some significant differences between SBC-91 and ASCE 7-88:

- SBC-91 does not account for the fact that the probability distribution of extreme winds in hurricanes differs from that for extratropical storms.

- SBC-91 recognizes only one wind exposure category which, in essence, corresponds to exposure category C in ASCE 7-88.

- Internal pressure coefficients are combined with the external pressure coefficients, the value of the internal pressure coefficient corresponding to \pm 0.2 .

- The pressure coefficients, $\mathrm{GC}_{\mathrm{P}}$, obtained from wind tunnel studies have been multiplied by a factor of 0.8 . Among the arguments offered in support of this reduction is that extreme winds seldom correspond to the critical wind direction (See Section 4.5.1). 
For hurricane-prone regions, the combined effect of the 0.8 reduction factor and of ignoring the difference in wind-speed probability distributions is to reduce the SBC-91 design wind loads to approximately 75 percent of the loads specified by ASCE 7-88. (Note that $0.8 /(1.05)^{2}=0.73$, the factor of 1.05 being the importance factor applied to the basic wind speed given in ASCE 7-88).

\subsubsection{The 0.8 Factor Applied to SBC-91:}

In recommending values of the pressure coefficients, $\mathrm{GC}_{\mathrm{P}}$, for inclusion in the ASCE Standard (then designated as ANSI A58.1-1982) researchers at the University of Western Ontario proposed a reduction factor of 0.8 (Davenport and Surry 1979). Arguments offered in support of the proposed reduction factor included the following:

1) Although 20 percent of the experimental pressure coefficients measured may be slightly greater than those designated, this figure still implies that 80 percent of the structures and/or roof areas in open country terrain see pressure coefficients which are less than those designated, sometimes appreciably so. Thus, in a limited sense, the risk of higher pressure coefficients is concentrated on small areas of some buildings.

2) When considering the total population of buildings affected by these design pressures (not pressure coefficients), the majority of buildings are not in open country areas but in urban terrain. In these areas, the general trend is for mean pressures to be appreciably less and peak pressures marginally less (about 10 percent on the average) than those in open terrain.

3) The ranges of wind direction for which the maximum and minimum peak pressure coefficients apply are generally narrow. (Even in individual zones they do not necessarily occur for the same wind direction.) Thus, the effective pressure coefficient given by the ratio of the once-in-50-years (say) pressure to the velocity pressure based on the once-in-50-years wind speed will always be less than the maximum peak pressure coefficient. Studies on the influence of wind direction (Davenport 1977; Tryggvason 1979) suggest that the so-called "effective pressure coefficient" is approximately $70-80$ percent of the maximum (minimum) pressure coefficient.

4) Most pressure coefficients have to be applied in conjunction with internal pressure. The maximum difference between external and internal pressures is somewhat less than the difference of the maxima.

The Subcommittee on Wind Loads did not accept the recommendation of a 0.8 reduction factor based on the following arguments (Mehta 1984):

1) Response characteristics of pressure measuring systems used in wind tunnel tests 
are such that one-second peak pressures in full scale may be underestimated in wind tunnel results by as much as 10 percent (Marshall and Reinhold 1981).

2) The directions investigated (in the wind tunnel studies) were in most cases limited to 45-degree increments of wind azimuth; thus the data tend to underestimate the true peak coefficients for critical wind directions.

3) Tropical storms, such as hurricanes, subject buildings to winds from many directions, thus creating critical wind loads for at least some of the cladding and components. Failure of one component or cladding element can lead to progressive failure of other members in a building. These progressive failure effects are not well known as yet.

4) In suburban areas, buildings are randomly oriented. High winds from any direction are likely to cause maximum peak pressures on components of several buildings. If those components experiencing maximum peak pressures fail, they could cause windborne debris impact damage to surrounding buildings. The current state-of-knowledge is unable to account for the uncertainty of windborne debris damage.

5) The wind-tunnel measured values were divided by a constant of 1.69 to make them consistent with fastest-mile wind speeds. This constant is not an exact value; there is a degree of uncertainty in the constant.

6) Traditionally, pressure coefficient values are the envelope of the maximum values obtained in the experiments. There is no safety factor in the pressure coefficient values. For the sake of consistency in the Standard, pressure coefficient values should not be adjusted upward or downward from the measured values.

\subsection{Manufactured Housing Institute (Proposed Requirements)}

Based in part on experience gained from Hurricane Andrew, the Manufactured Housing Institute (MHI) has developed a set of design wind load criteria for consideration as a replacement for the current provisions of the MHCSS (MHI 1992). In general, the design wind loads contained in the MHI proposal correspond to those of SBC-91 with the exception that simplification of external pressure zones is achieved by combining zones for the design of cladding, thus requiring higher design pressures for interior zones of the walls and roof. Three wind speed zones are proposed with corresponding fastest-mile design speeds of $35.8,40.2$ and $49.2 \mathrm{~m} / \mathrm{s}(80,90$ and $110 \mathrm{mph})$. Zone III includes the area bounded by the $35.8 \mathrm{~m} / \mathrm{s}(80 \mathrm{mph})$ isotach on the ASCE 7-88 wind speed map and the Gulf and Atlantic coasts from Mexico to the North Carolina/Virginia state line. Also included in Zone III is Puerto Rico. Zone II includes the remainder of this bounded area north to Canada and that part of Alaska between the $35.8 \mathrm{~m} / \mathrm{s}$ $(80 \mathrm{mph})$ isotach and the coastline. Note, however, that this portion of Alaska is assigned to Zone III in the text of the design criteria. All other areas are defined as Zone I. 


\subsection{Comparison of Design Loads}

To provide a quantitative comparison of the design wind loads required by the codes and standards referenced herein, loads have been calculated for a manufactured home assumed to be located in the area where Hurricane Andrew made landfall. It is assumed that the wind exposure corresponds to exposure category $\mathrm{C}$ in ASCE 7-88 and that the manufactured home has the following dimensions:

$$
\begin{aligned}
& \text { Width }=4.270 \mathrm{~m}(14 \mathrm{ft}) \\
& \text { Length }=20.120 \mathrm{~m}(66 \mathrm{ft}) \\
& \text { Eave Height }=3.200 \mathrm{~m}(10.5 \mathrm{ft}) \\
& \text { Roof Slope }=15 \text { degrees } \\
& \text { No major openings in walls or roof }
\end{aligned}
$$

Detailed calculations are provided in the Appendix of this document and the design loads are summarized in Table 6. To aid in this comparison, ratios of the loads to the corresponding ASCE 7-88 design wind loads are listed in Table 6 and the calculated design loads are plotted in Figures 6 through 11. To be consistent with ASCE 7-88, the design loads are presented in the following order:

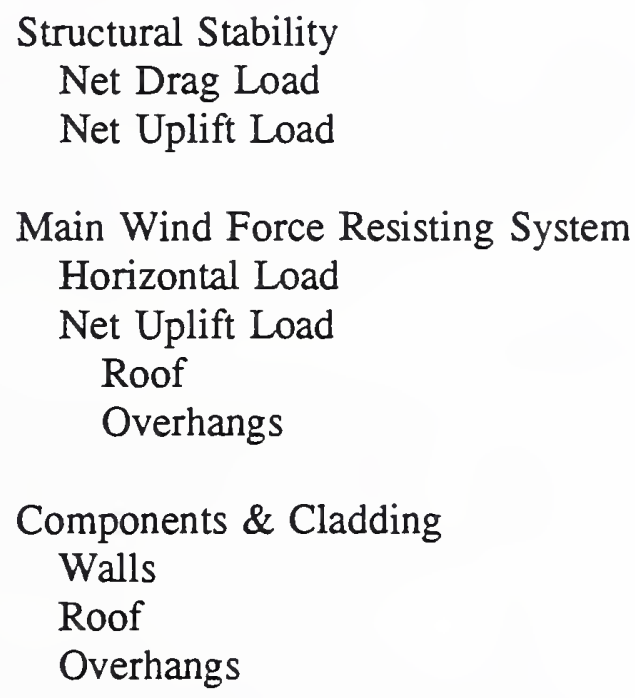

For the area where Hurricane Andrew made landfall, ASCE 7-88 specifies a basic wind speed ( 0.02 annual probability of exceedance) of $49.2 \mathrm{~m} / \mathrm{s}(110 \mathrm{mph})$. This is the fastest-mile speed at a height of $10 \mathrm{~m}(32.8 \mathrm{ft})$ in exposure category $\mathrm{C}$. The corresponding design speed for exposure category $C$ is $(1.05)(49.2)=51.9 \mathrm{~m} / \mathrm{s}(116 \mathrm{mph})$. Sec. 2.4 .2 of the ASCE Standard lists basic combinations of factored loads which are to be exceeded by the design strength when a load and resistance factor design (LRFD) approach is used. The specified load factor for wind is 1.3. Thus, at the strength limit state, the corresponding fastest-mile wind speed is $(51.9)(1.3)^{0.5}=59.0 \mathrm{~m} / \mathrm{s}(132 \mathrm{mph})$. 


\subsubsection{Structural Stability:}

With regard to the current provisions of the MHCSS, it is seen that the loads for structural stability (sliding and uplift) are only about half the values obtained from ASCE 7-88. In fact, the loads specified by MHCSS correspond to a basic wind speed (fastest mile at 10-m height in exposure category C) of 35.8 to $38.0 \mathrm{~m} / \mathrm{s}$ ( 80 to $85 \mathrm{mph}$ ).

The area-averaged drag and uplift loads required by SFBC- 88 for the coastal zone are 68 and 80 percent, respectively, of the corresponding loads required by ASCE 7-88. In terms of the ASCE requirements, these loads correspond to basic wind speeds of from 40.7 to $43.8 \mathrm{~m} / \mathrm{s}(91$ to $98 \mathrm{mph})$. Recall that SFBC-88 requires a design speed of $53.6 \mathrm{~m} / \mathrm{s}(120 \mathrm{mph})$, although the corresponding averaging time is not specified. For the coastal building zone, design for a $100-\mathrm{yr}$ event is required. The corresponding ASCE 7-88 design speed is (1.11)(49.2) $=54.5 \mathrm{~m} / \mathrm{s}(122$ mph) fastest mile.

For the design case being considered here, SBC-91 requires average drag and uplift loads that are approximately 75 percent of the values required by ASCE 7-88. Although the basic wind speeds and the primary data source for lift and drag coefficients are the same, the SBC-91 loads are lower because of the 0.8 reduction factor noted earlier and disregard for the fact that the wind speed probability distributions for hurricanes and for extratropical storms are different.

As expected, the drag load obtained from the MHI proposed criteria is in good agreement with the SBC-91 value. However, the average uplift load is higher than the SBC-91 value. In fact it exceeds the ASCE 7-88 requirement by 4 percent. The reason for this higher value is the simplification of roof loading by extending the zone of highest loading to include the entire roof.

\subsubsection{Main Wind Force Resisting System (MWFRS):}

Wind loads for the design of the MWFRS correspond to the applied drag and uplift forces plus the effects of internal pressures based on the assumption that the building envelope has no major openings. Where no internal pressures are specified, as is the case for the MHCSS and SFBC88 requirements, the loads for structural stability and for design of the MWFRS are identical.

Since all of the drag load is applied to the windward wall, the MHCSS requirement for design of the MWFRS becomes 70 percent of the corresponding value from ASCE 7-88. However, the MHCSS does not provide for negative (suction) pressures on the leeward wall. Since the MHCSS does not provide for internal pressures, the uplift requirement for design of the MWFRS becomes only 42 percent of the corresponding ASCE 7-88 load. Because the internal pressures are not specified, the same trend is observed for the MWFRS design loads required by SFBC- 88 .

Load contributions from internal pressures are included in the SBC-91 coefficients for the design of primary structural systems (MWFRS). For enclosed buildings, the internal pressure coefficients are \pm 0.2 and in calculating the drag and uplift forces for stability, these coefficients 
were not included. Because the range of internal pressures specified by ASCE 7-88 is only slightly greater ( \pm 0.25 for buildings without openings), the ratios of the area-averaged loads for design of the MWFRS and for structural stability are the same. Since the SBC-91 provisions assign higher loads to the end bays than to the interior bays, the end bay loads for design of the MWFRS approach 90 percent of the values required by ASCE 7-88. However, the areaaveraged uplift load is only 75 percent of that required by ASCE 7-88.

The design wind load requirements proposed by MHI do not treat internal pressures as a separate entity; therefore, the loads for structural stability and the loads for design of the MWFRS are identical.

\subsubsection{Components and Cladding:}

Because of the differing zone definitions for components and cladding, and because of the various areas assigned to these zones, the comparison of design loads among the codes and standards cited herein is not straightforward. In addition, ASCE 7-88 and SBC-91 provide for load reduction with increasing tributary area while the other documents do not. For walls, the MHCSS requirements range from 55 to 73 percent of the ASCE 7-88 loads. However, this applies only to positive pressures since the MHCSS does not provide for negative (suction) pressures on walls. For SFBC-88, the range is 57 to 88 percent and for SBC-91 the range is 61 to 75 percent. The agreement between ASCE 7-88 and the MHI proposed requirements ranges from 57 to 102 percent. Again, the simplification of zoning results in higher design pressures than required by SBC-91 for certain zones.

The MHCSS requirements for the design of components and cladding for roofs range from 17 to 41 percent of the pressures required by ASCE 7-88 and the corresponding range for the SFBC- 88 requirements is 31 to 75 percent. The range for SBC- 91 is 39 to 76 percent. The largest difference between SBC-91 and ASCE 7-88 occurs on small tributary areas (A $\leq 0.93$ $\mathrm{m}^{2}\left(10 \mathrm{ft}^{2}\right)$ ) located in the roof edge zone above the sidewalls. The design pressures proposed by $\mathrm{MHI}$ are in good agreement with the SBC-91 values, except for the edge zone at gable ends where the intense negative pressures required by SBC- 91 have not been accounted for.

For overhangs, the MHCSS requires a loading that is 2.5 times the design uplift load for the roof or 46 to 69 percent of the loads required by ASCE 7-88. The corresponding range for SFBC- 88 is 49 to 74 percent. The range for SBC-91 is 55 to 76 percent with the largest difference again involving small tributary areas located above the sidewalls. As with the roof edge zones, the MHI design pressures for overhangs are in good agreement with those of SBC91. An exception is overhangs at gable ends where SBC-91 allows a substantial load reduction for large tributary areas while the MHI proposed requirements do not.

\subsection{Summary}

The wind load provisions of selected codes and standards have been compared in this chapter, and a quantitative comparison of design loads has been made by means of detailed load 
calculations for a structure of specific geometry and dimensions assumed to be located in the area affected by Hurricane Andrew. For this location, the basic wind speed (fastest-mile speed at $10 \mathrm{~m}(32.8 \mathrm{ft})$ in exposure category C) specified by ASCE $7-88$ is $49.2 \mathrm{~m} / \mathrm{s}(110 \mathrm{mph})$ and the corresponding design speed is $51.9 \mathrm{~m} / \mathrm{s}(116 \mathrm{mph})$. For a load and resistance factor design (LRFD) approach, the strength limit state corresponds to a fastest-mile speed of $59.0 \mathrm{~m} / \mathrm{s}(132$ $\mathrm{mph}$ ). In general, the wind load requirements of ASCE 7-88 exceed those of the other codes and standards included in this comparison.

Based on the requirements for structural stability (sliding and uplift), the design loads required by the MHCSS correspond to a basic wind speed of from 35.8 to $38.0 \mathrm{~m} / \mathrm{s}$ ( 80 to $85 \mathrm{mph}$ ). A similar analysis of the SFBC-88 provisions indicates that the specified design speed of $53.6 \mathrm{~m} / \mathrm{s}$ (120 mph) is, in effect, a gust speed. The drag and uplift loads required by SFBC-88 correspond to basic wind speeds of 40.7 and $43.8 \mathrm{~m} / \mathrm{s}$ (91 and $98 \mathrm{mph}$ ), respectively.

Although ASCE 7-88 and SBC-91 reference the same basic wind speed of $49.2 \mathrm{~m} / \mathrm{s}$ (110 mph) and the same source of pressure coefficient data, SBC-91 requires average drag and uplift loads that are approximately 75 percent of the values required by ASCE 7-88. The major reasons for this difference in design loads are a reduction factor of 0.8 applied to the pressure coefficients used in SBC-91 and disregard for the fact that the wind speed probability distributions for hurricanes and for extratropical storms are different. The MHI proposed wind load criteria are based on the provisions of SBC-91. However, simplification of the MHI proposed loading requirements by combining pressure zones results in design loads that, in general, are higher than those required by SBC-91. 


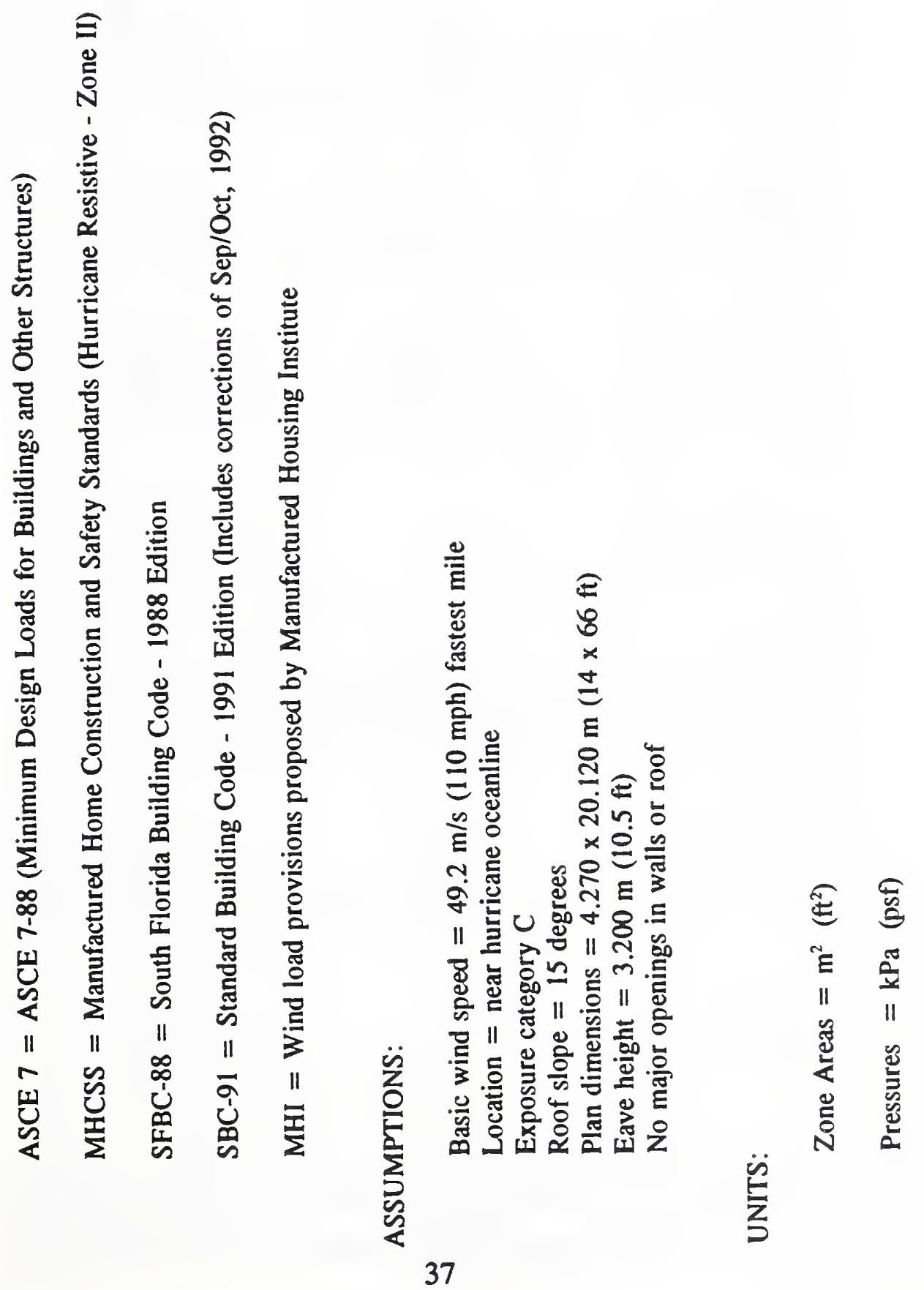




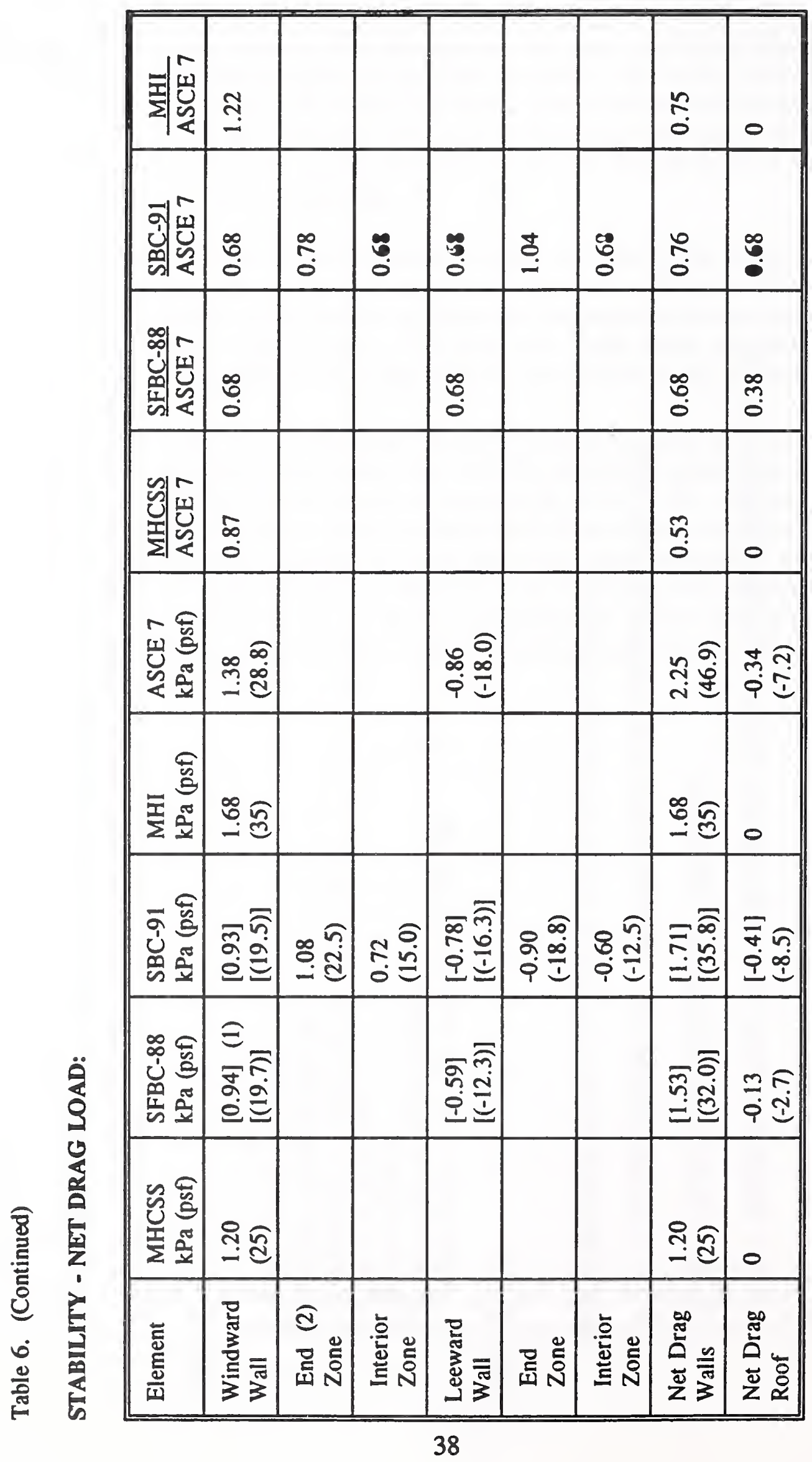




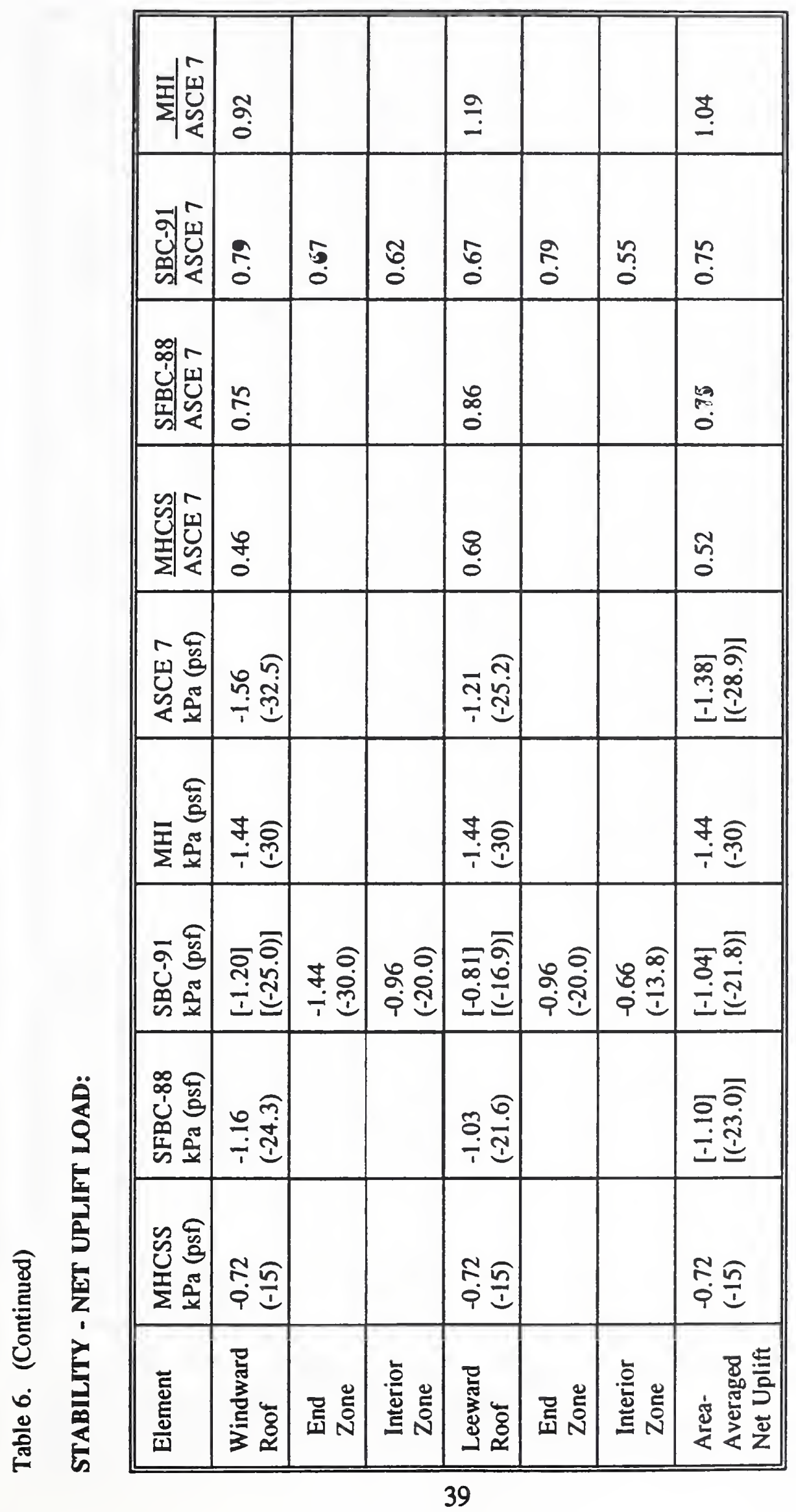




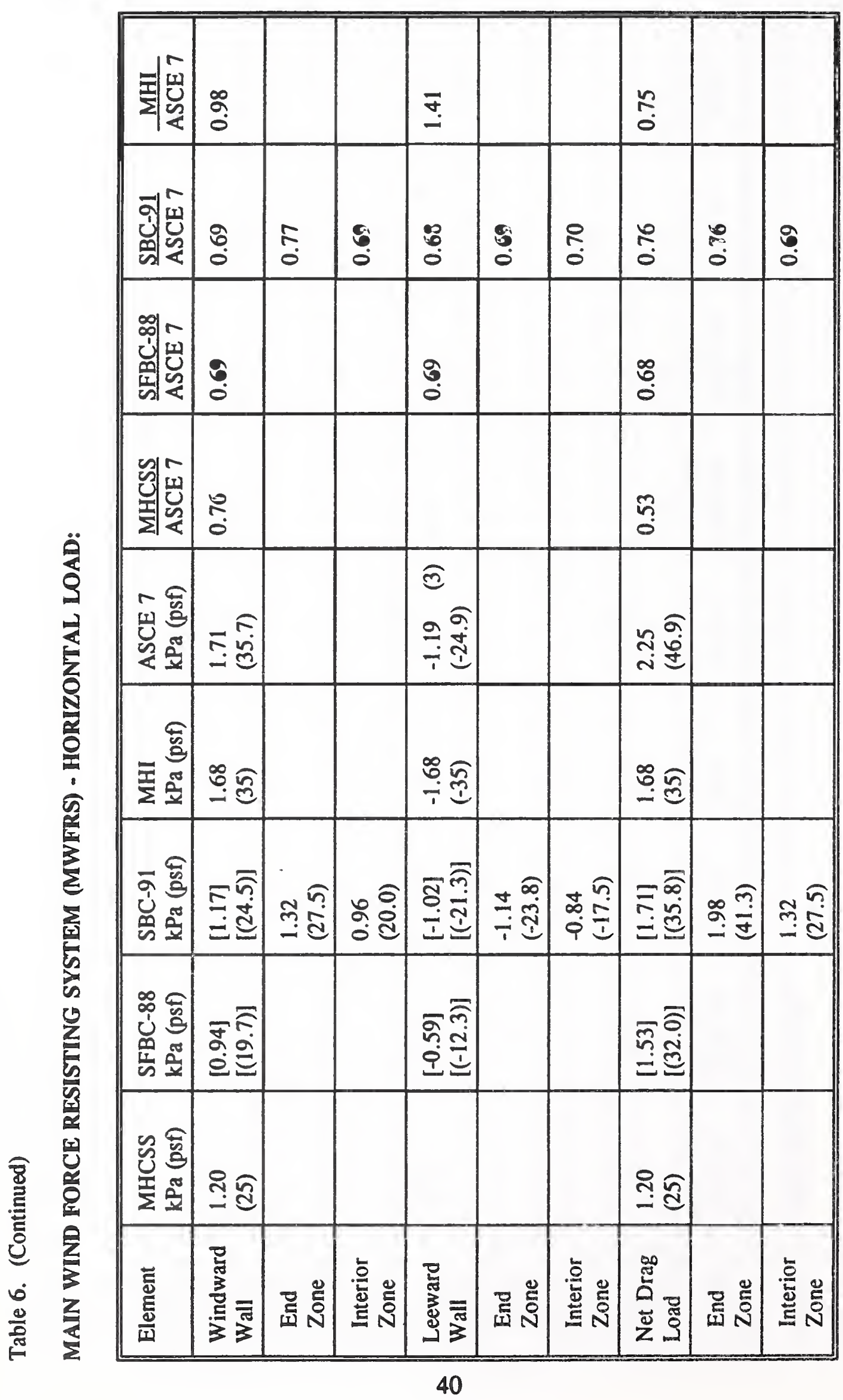




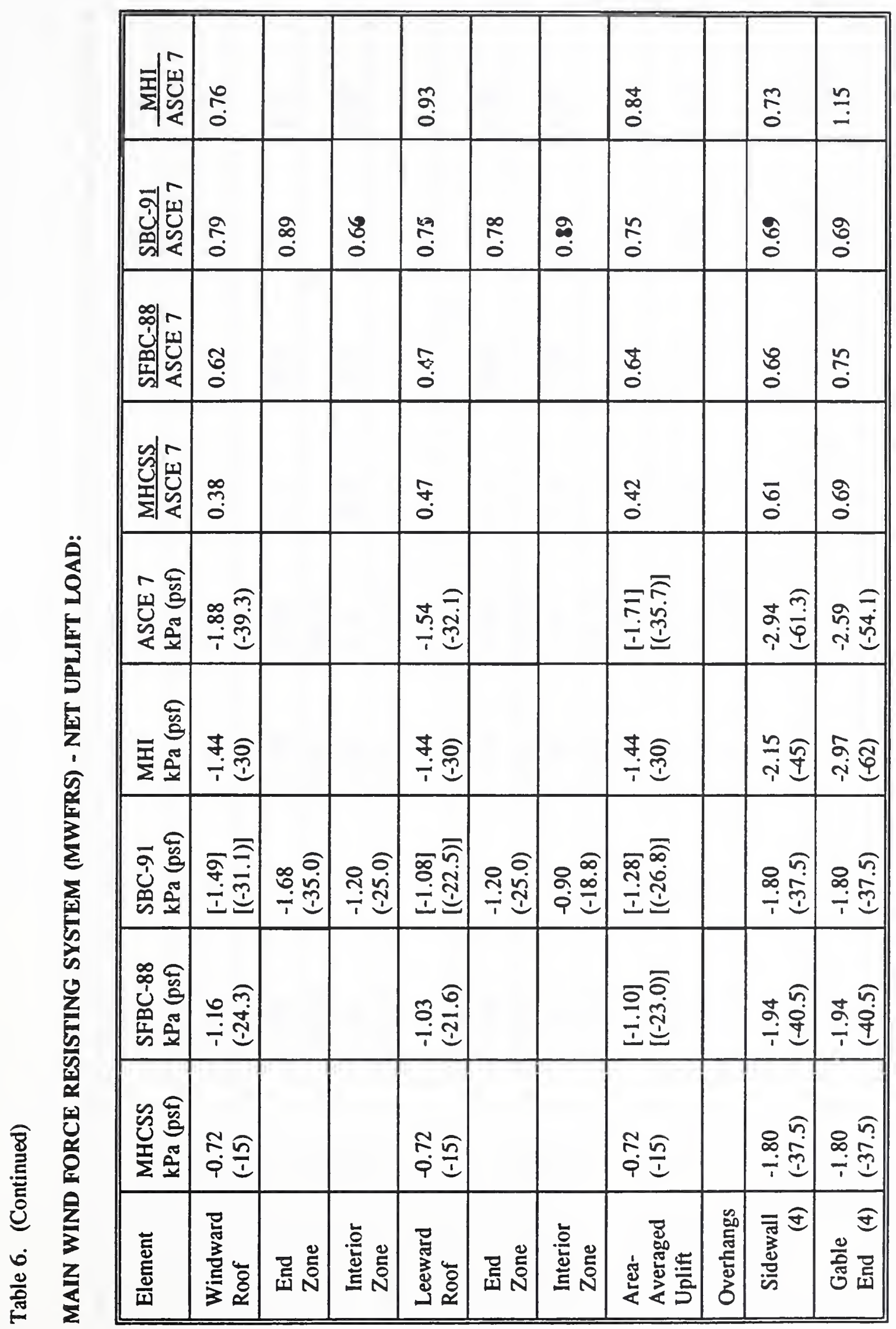




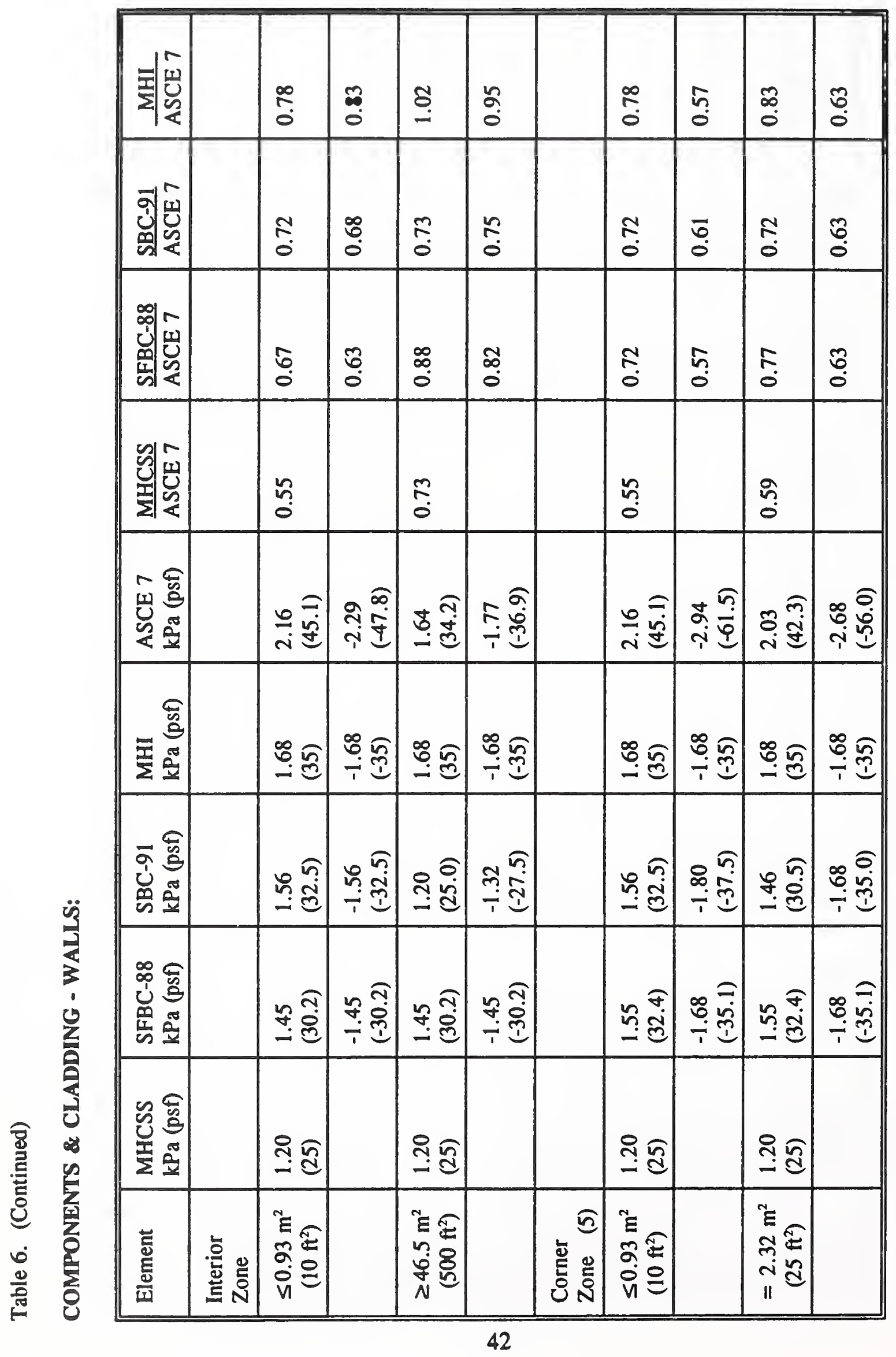




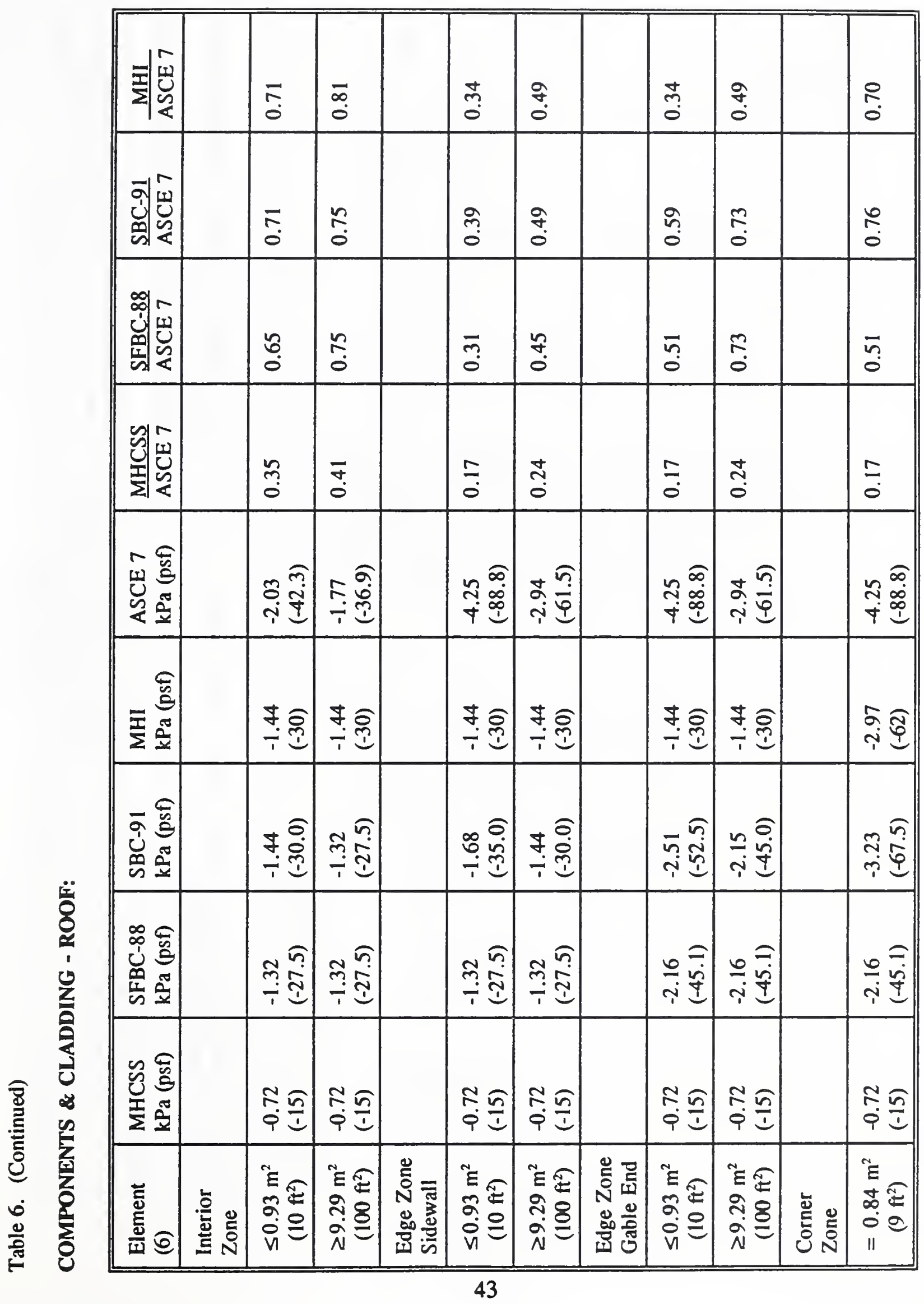




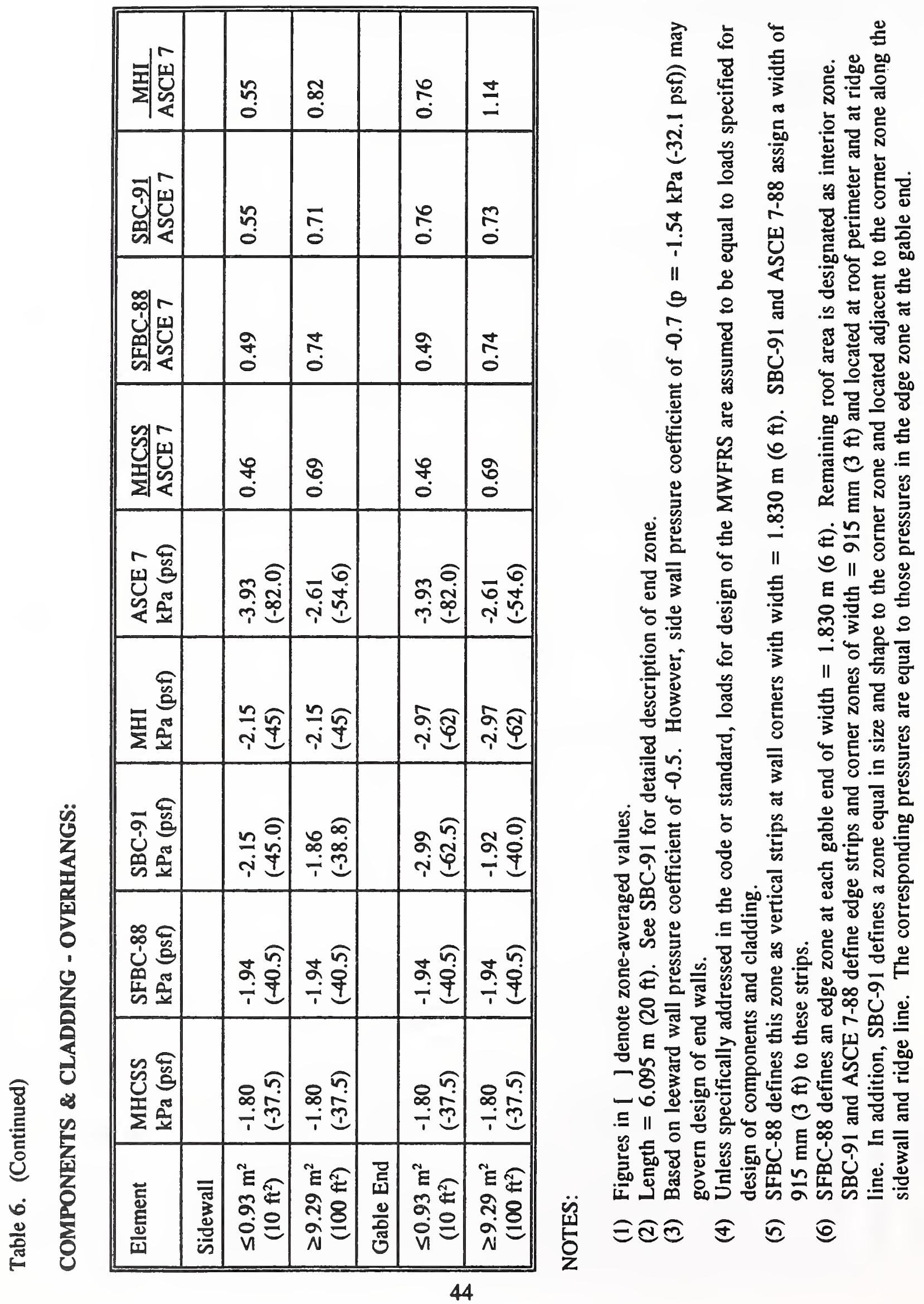




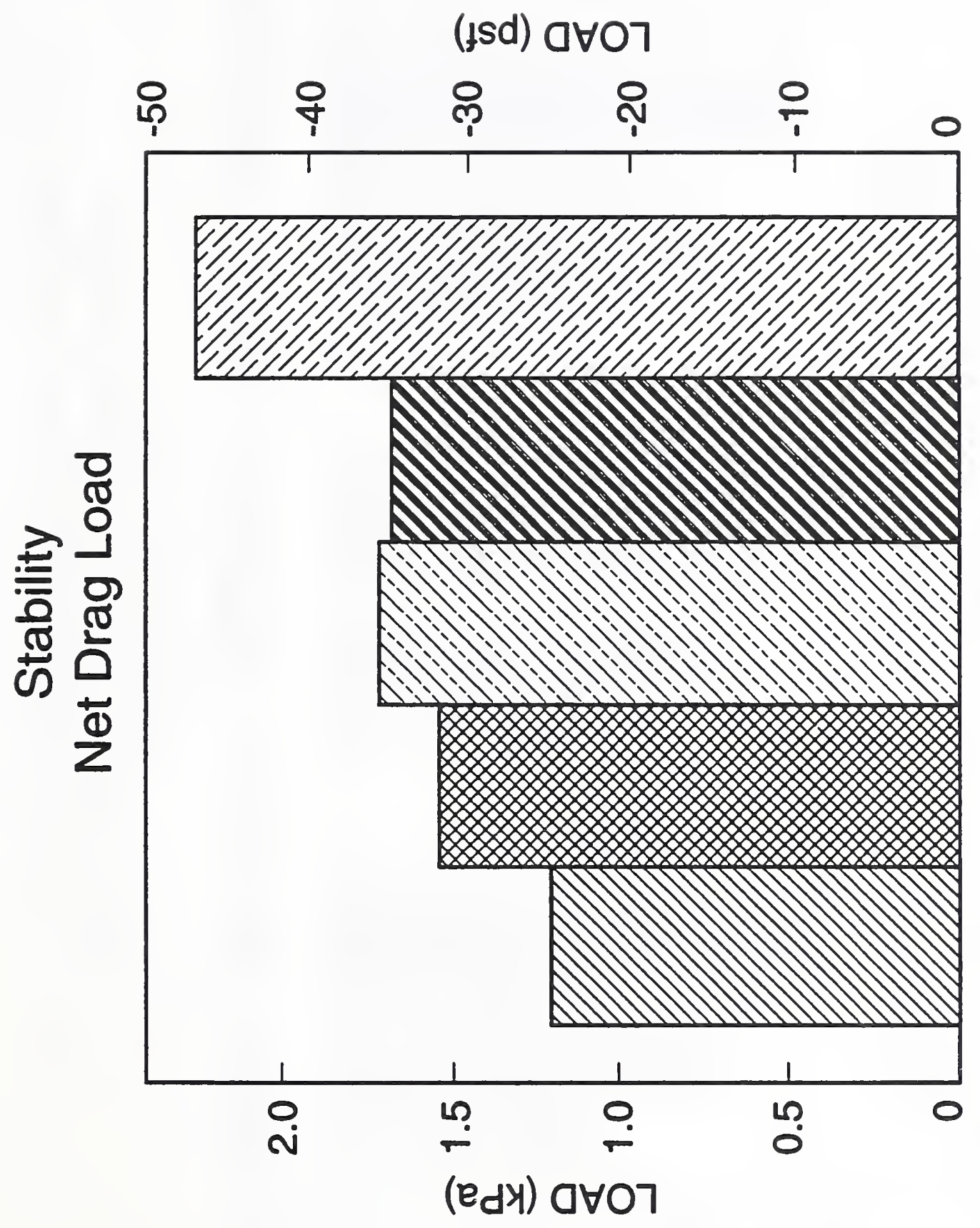

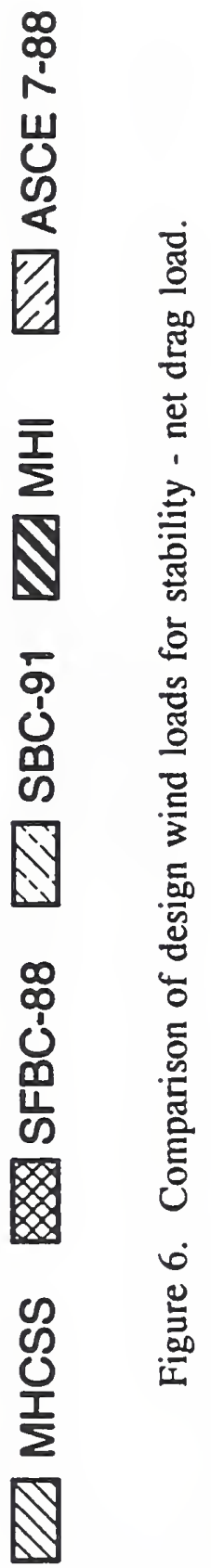




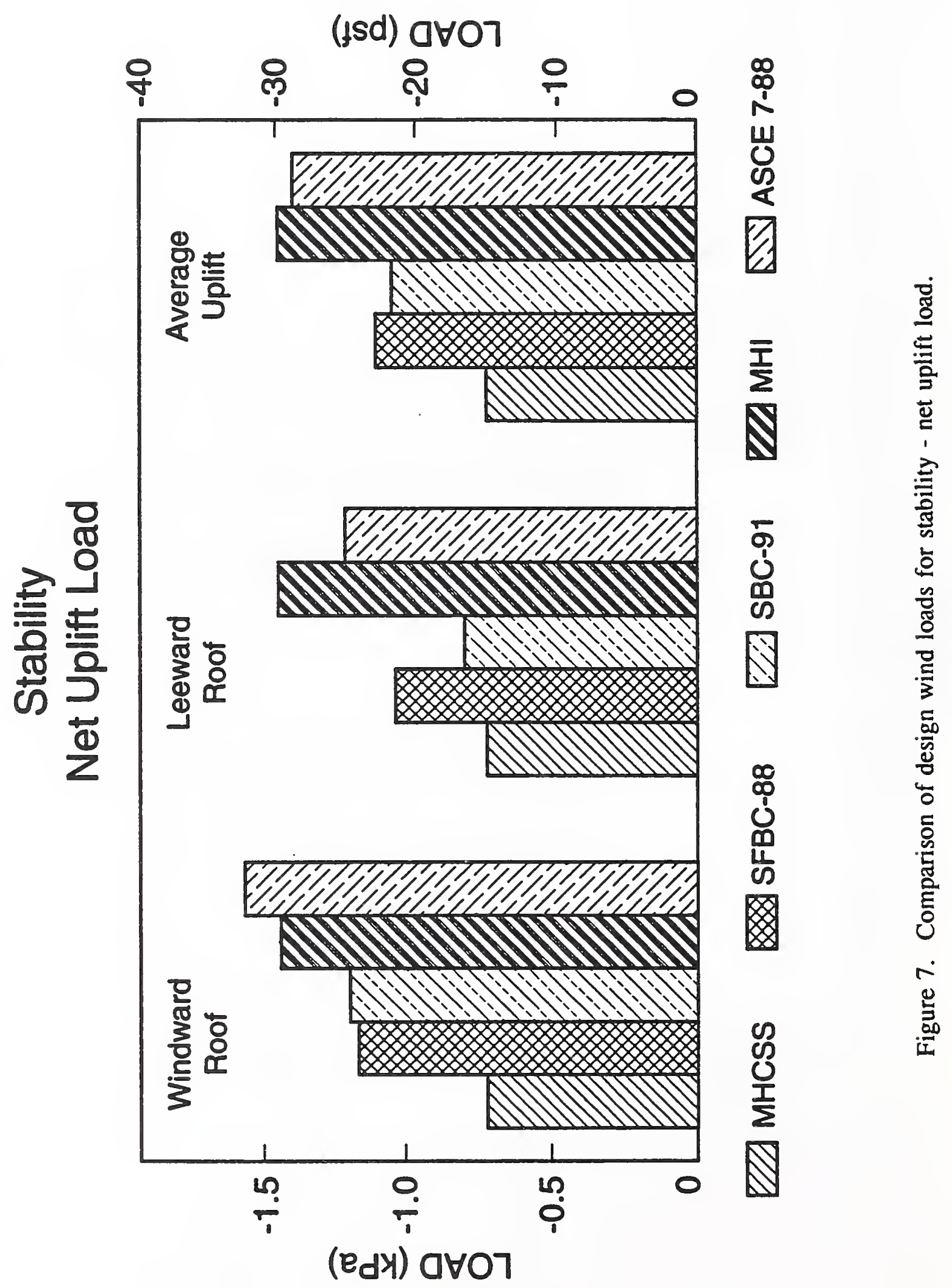




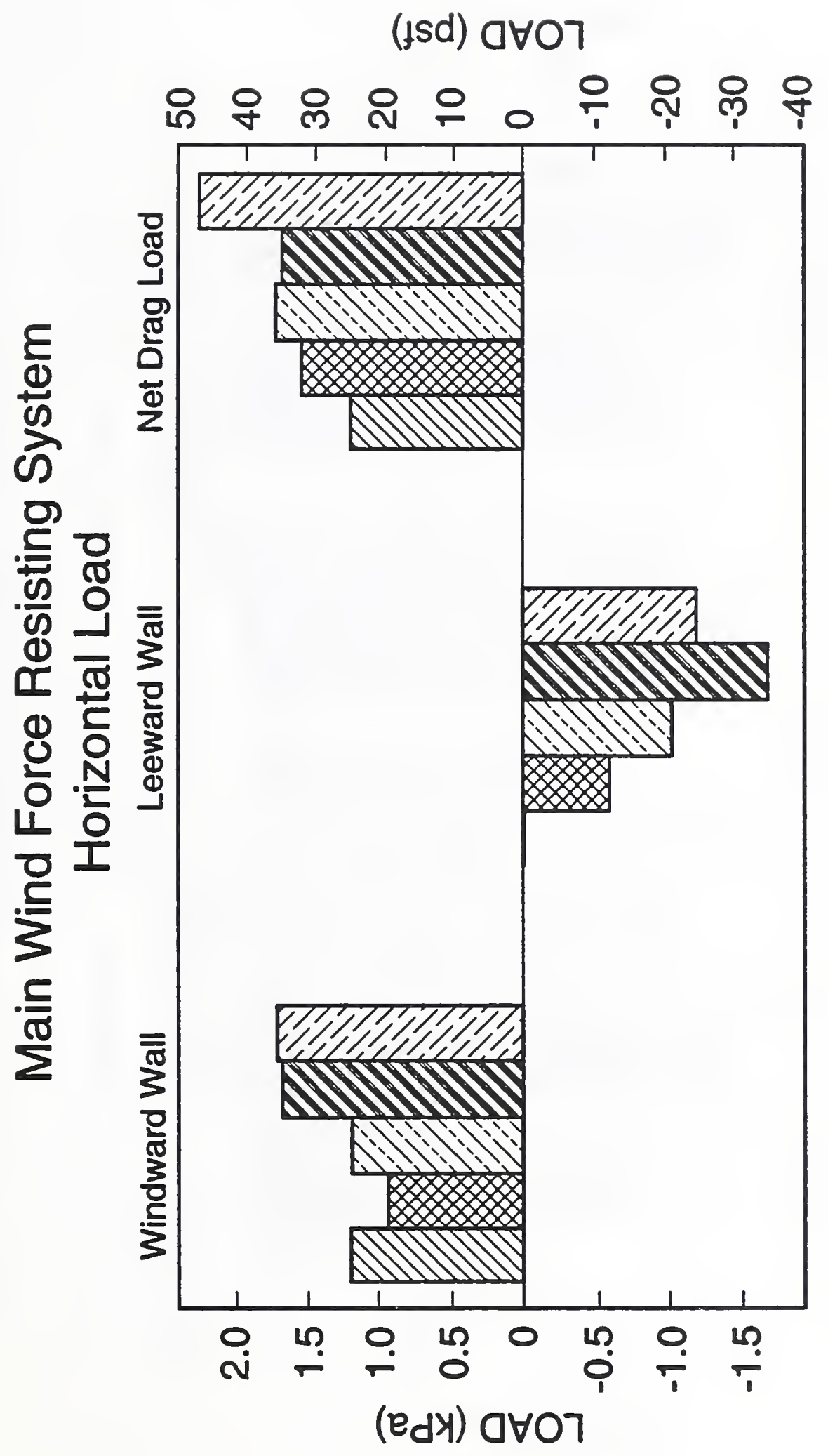

$\infty$
$\infty$
1

U

응

I

N

.

का है

o

$\infty$
$\infty$
$j$
0
0
0
0
0

$\infty$
0
$\mathcal{I}$
$\Sigma$

ڤ

NV

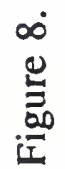




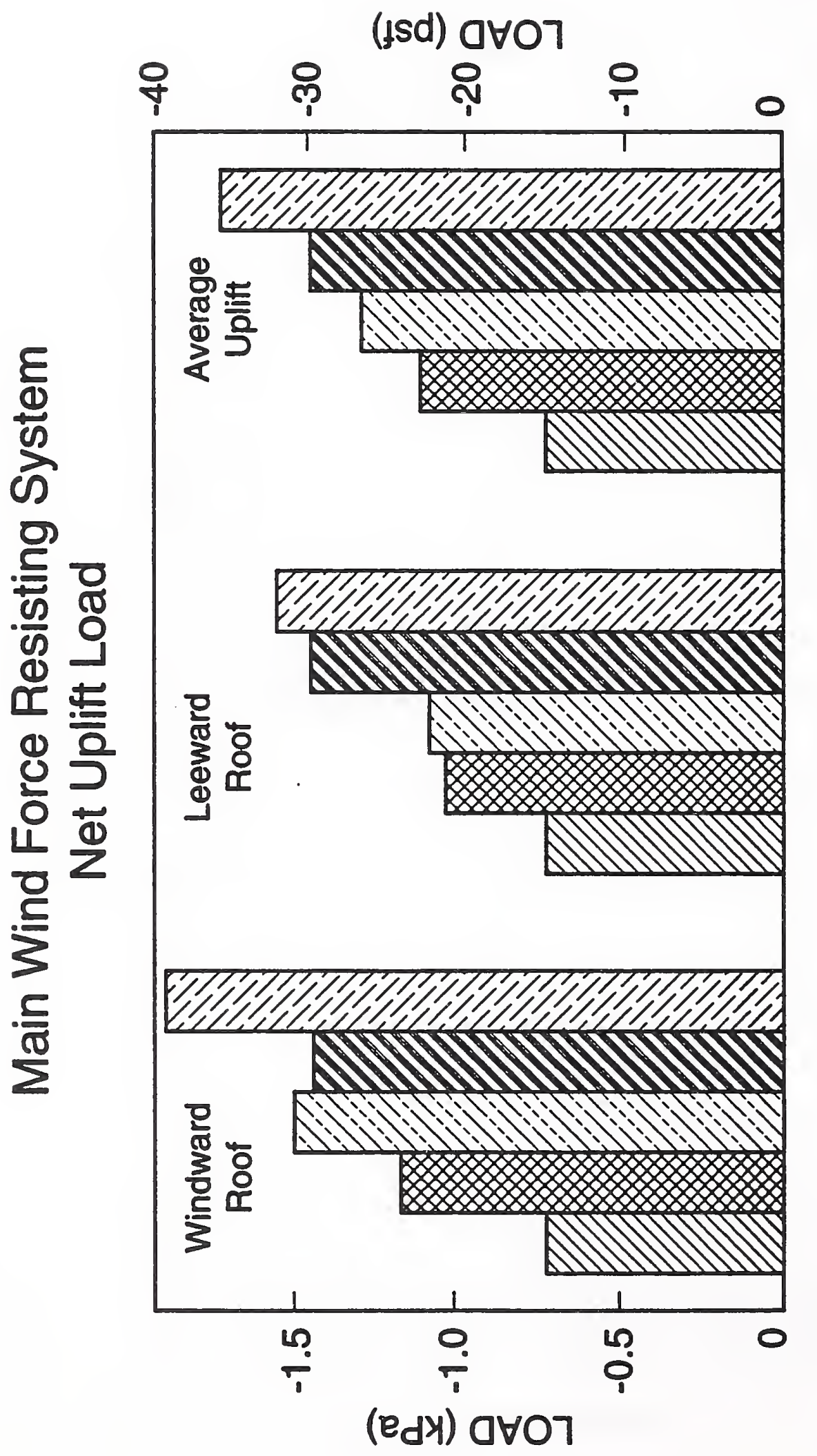

$\infty$
$\infty$
1
$u$
0
0
$\square$
$\square$

焉

$\underset{\mathbf{N}}{\overline{\mathbf{Y}}}$

$\frac{5}{2}$

$\frac{\infty}{5}$

5
0
0
0
5

$\infty$
$\infty$
$\vdots$
0
$\frac{1}{\infty}$
0

0
0
1

N

\%

क

a 


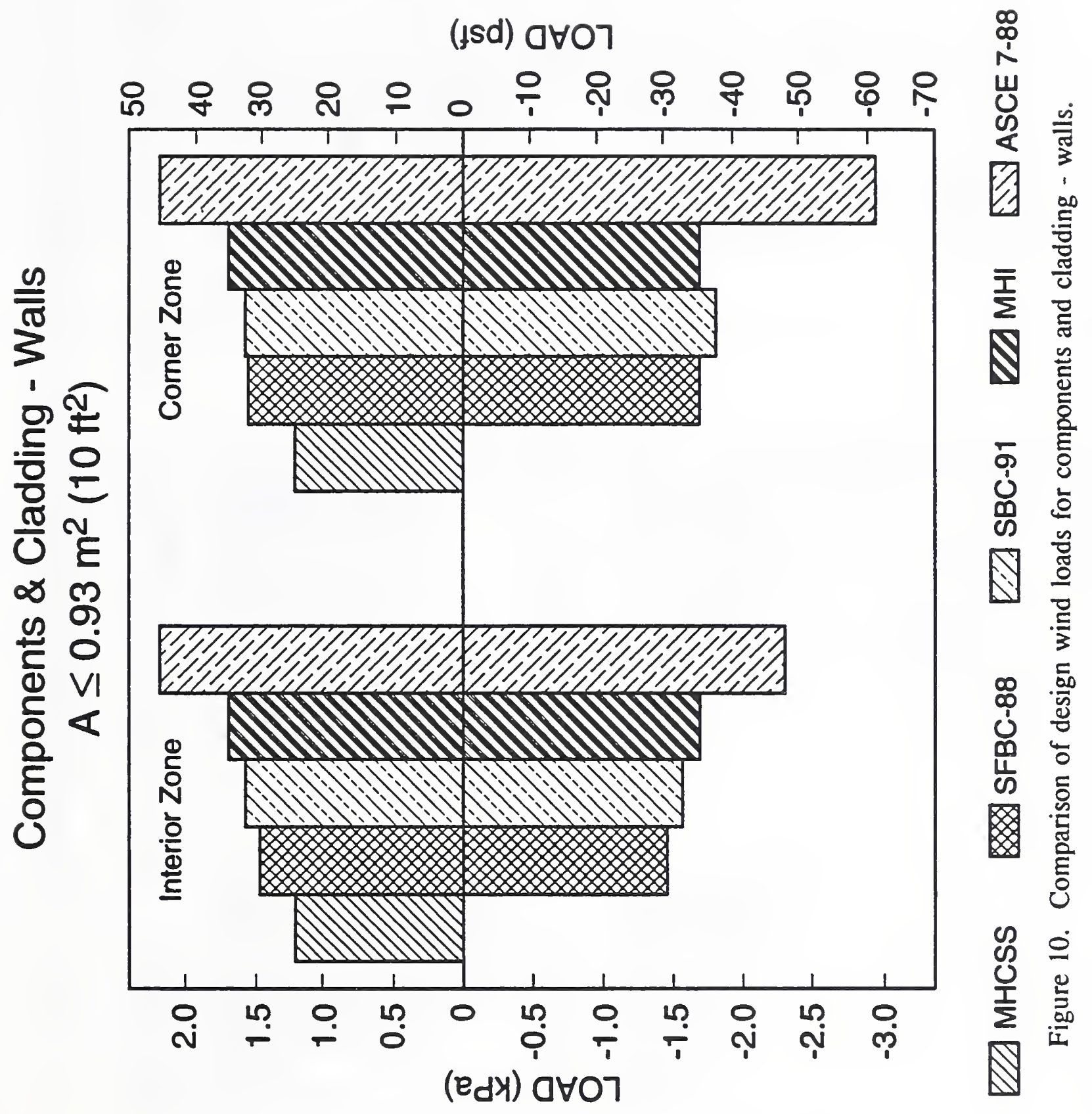




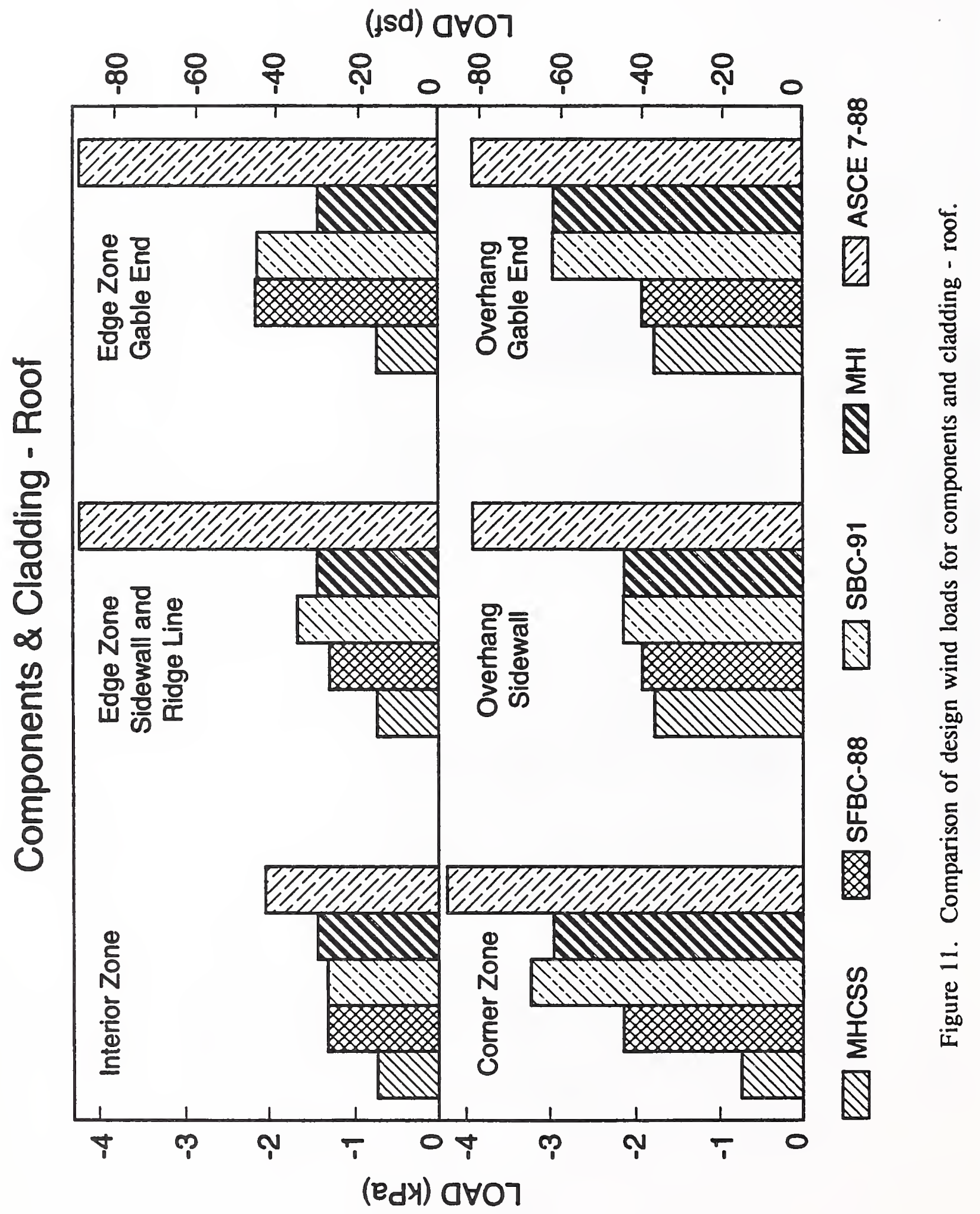




\subsection{HUD PROPOSED RULE}

\subsection{General}

In the months following Hurricane Andrew, the Department of Housing and Urban Development has developed a Proposed Rule (Dept. of HUD 1993) to replace the current wind load provisions of the MHCSS. This rule change is continuing and the material addressed here is subject to modification and refinement. The design wind loads specified in the Proposed Rule are based on the assumption of three wind speed zones as follows: Zone $I=35.8 \mathrm{~m} / \mathrm{s}(80 \mathrm{mph})$ or less; Zone II $=36.2-44.7 \mathrm{~m} / \mathrm{s}(81-100 \mathrm{mph})$; and Zone III $=45.1-49.2 \mathrm{~m} / \mathrm{s}(101-110 \mathrm{mph})$. The wind speed zones are shown in Figure 12, and the zone boundaries correspond approximately to the 35.8 and $44.7 \mathrm{~m} / \mathrm{s}$ (80 and $100 \mathrm{mph}$ ) isotachs along the Atlantic and Gulf Coasts as shown on the map of basic wind speeds denoted as Figure 1 in ASCE 7-88. The states of Alaska and Hawaii are designated as Zone III.

The velocity pressure in psf for each zone is obtained from the formula

$$
\mathrm{q}_{\mathrm{z}}=0.00256 \mathrm{~K}_{\mathrm{z}}(\mathrm{IV})^{2}
$$

where $\mathrm{K}_{\mathrm{Z}}$ is the velocity pressure exposure coefficient, $\mathrm{I}$ is the importance factor, and $\mathrm{V}$ is the upper-bound basic wind speed in mph for the respective zones. For Zone I, the importance factor is assumed equal to 1.0. For Zones II and III, where the distribution of extreme wind speeds is assumed to be dictated by hurricane winds, the importance factor is 1.05 . Thus the corresponding velocity pressures at the $10 \mathrm{~m}(32.8 \mathrm{ft})$ height for exposure category $\mathrm{C}$ are as follows: Zone I $=0.78 \mathrm{kPa}(16.38 \mathrm{psf})$; Zone II $=1.35 \mathrm{kPa}(28.22 \mathrm{psf})$; Zone III $=1.64 \mathrm{kPa}$ (34.15 psf). These velocity pressures and the velocity pressure exposure coefficients, gust response factors, and pressure coefficients listed in ASCE 7-88 are, with few exceptions, the basis for the proposed design wind loads prepared by HUD and listed in Table 7. The zones over which the wind loads of Table 7 act are defined in Figure 13, and the specified design loads for the three wind speed zones are plotted in Figures 14-16.

\subsection{Assumptions and Limitations}

Implicit in the design wind loads listed in Table 7 are the following assumptions and limitations:

- Consistent with the provisions of ASCE 7-88 for the design of buildings with heights less than or equal to $18.3 \mathrm{~m}(60 \mathrm{ft})$, the prescribed wind loads for the design of components and cladding apply to all wind exposure categories.

- The mean roof height of the structure does not exceed $4.570 \mathrm{~m} \mathrm{(15} \mathrm{ft),} \mathrm{and} \mathrm{the}$ minimum plan dimension does not exceed $9.140 \mathrm{~m}(30 \mathrm{ft})$.

o The roof slope, measured from horizontal, is greater than 10 degrees but not greater than 30 degrees. 


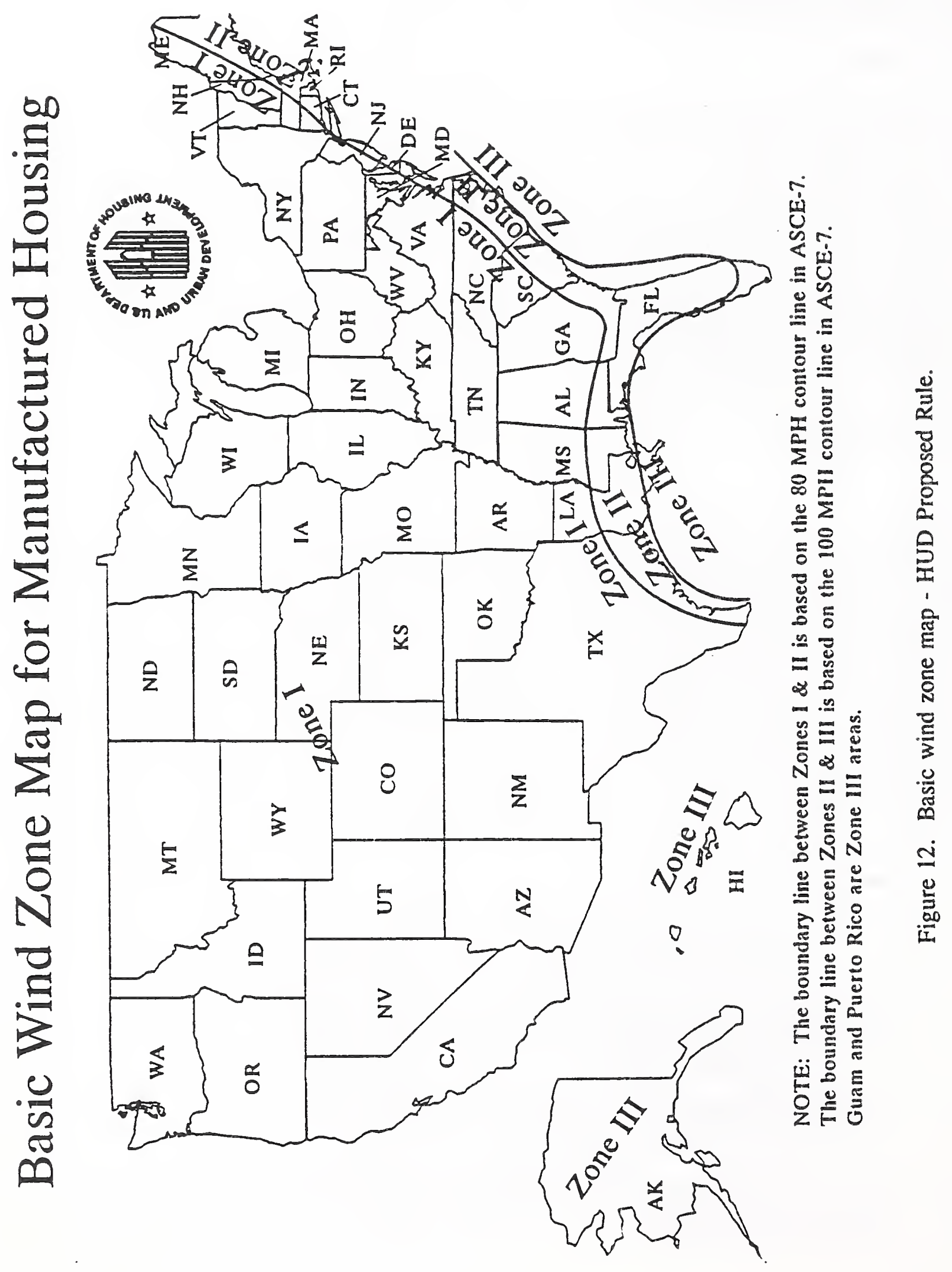




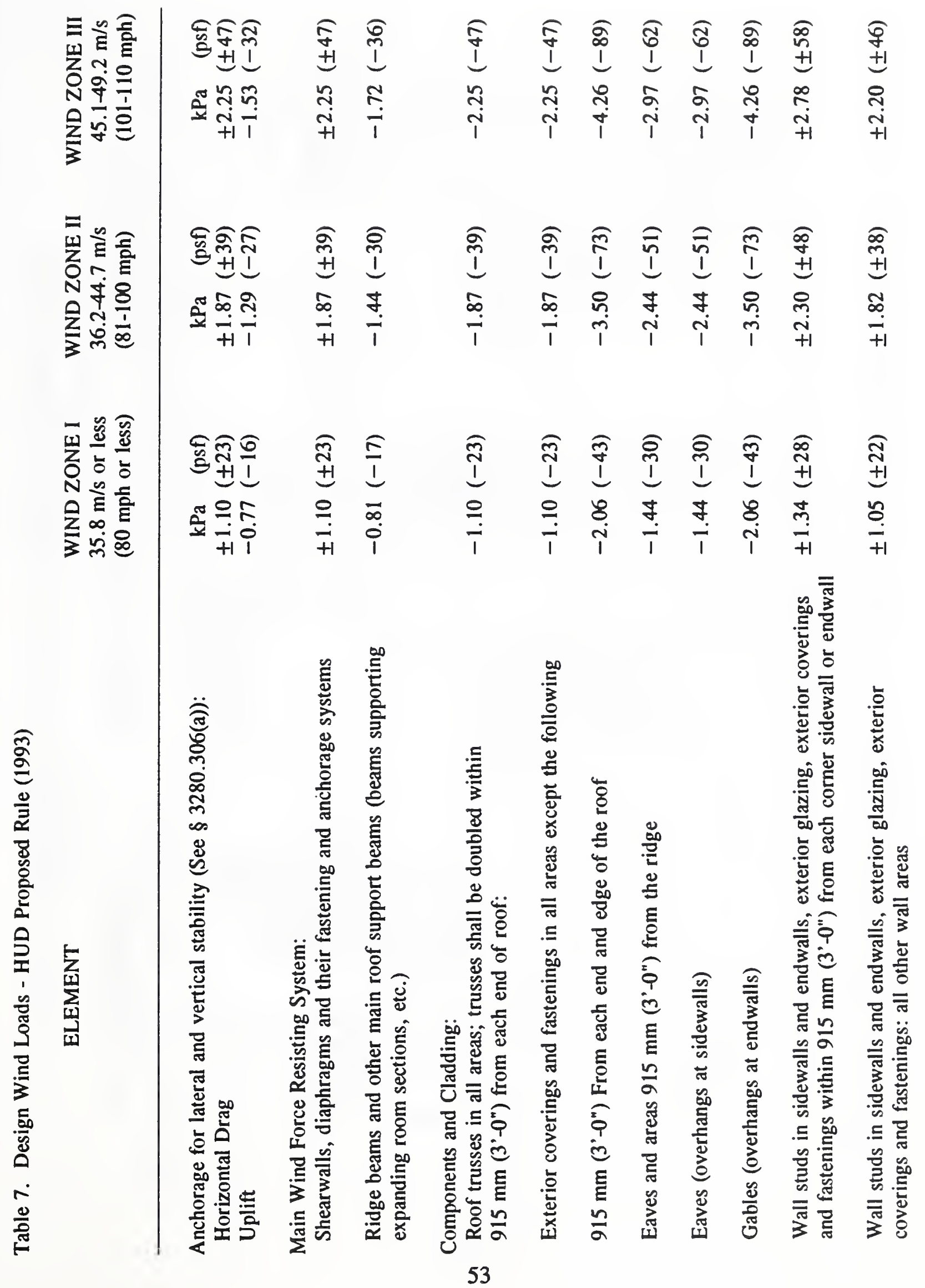




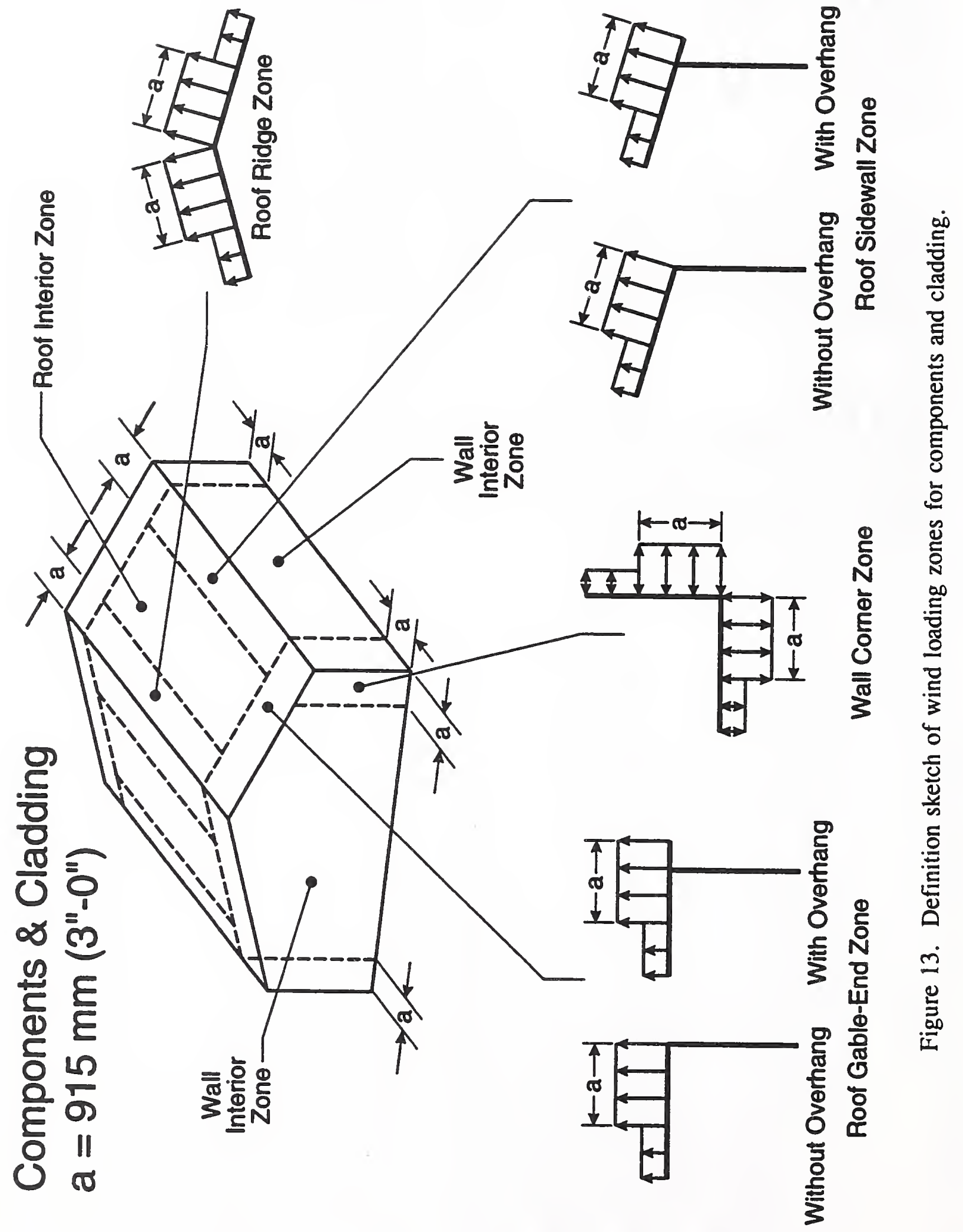




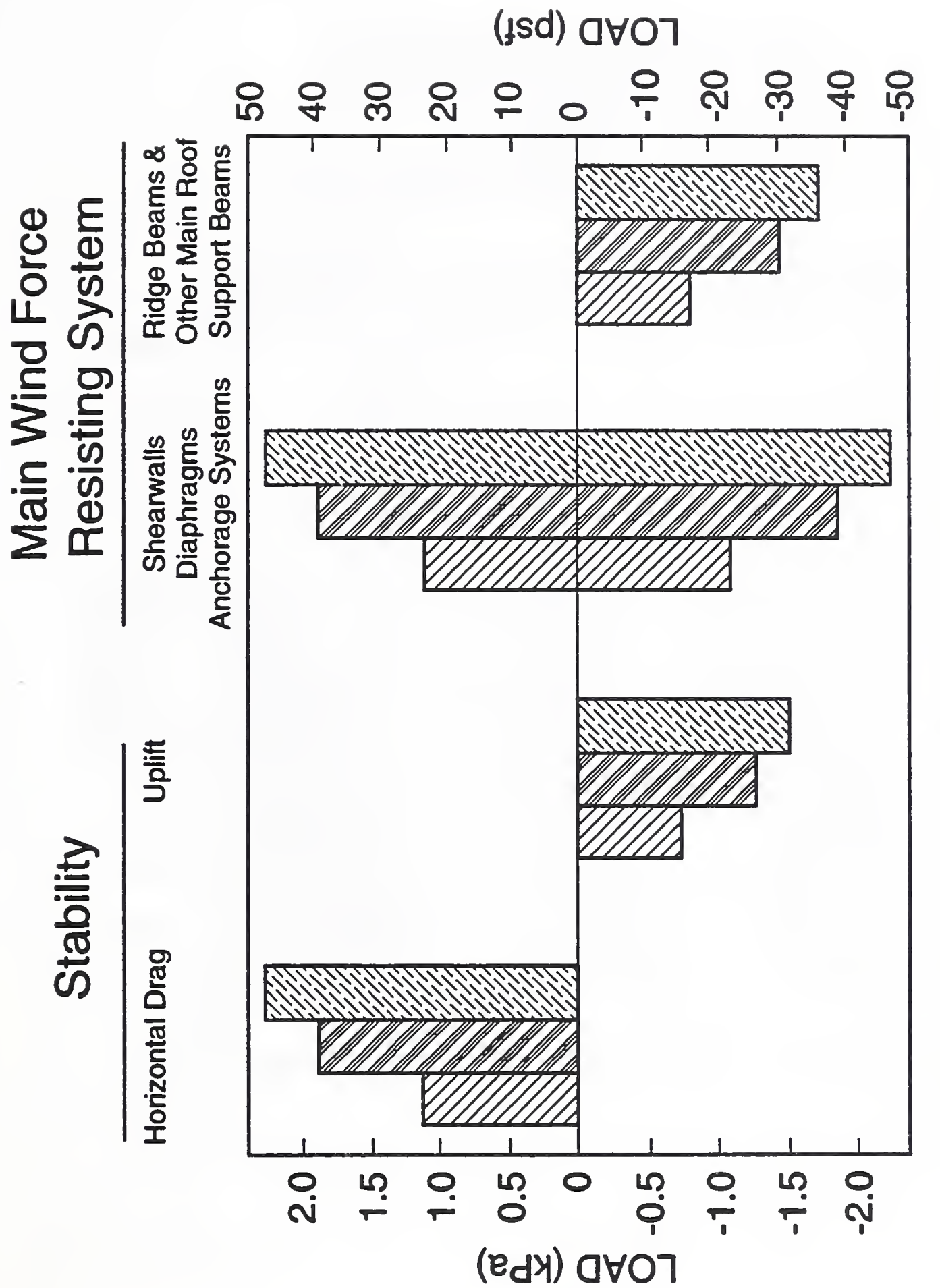

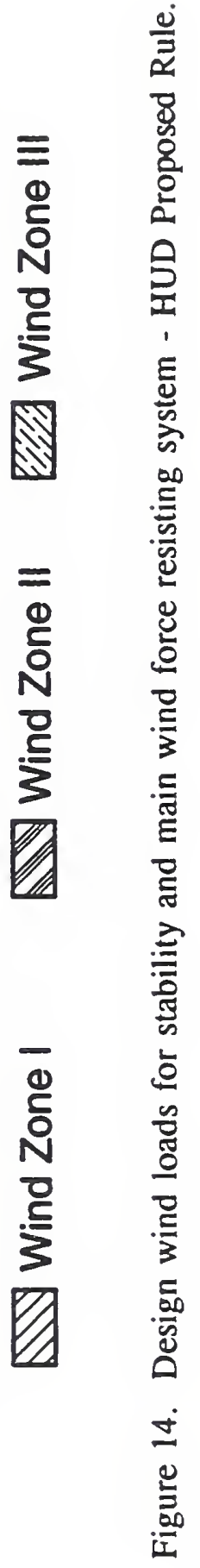




\section{Components \& Cladding Roof}

\section{Exterior Coverings \& Fastenings}

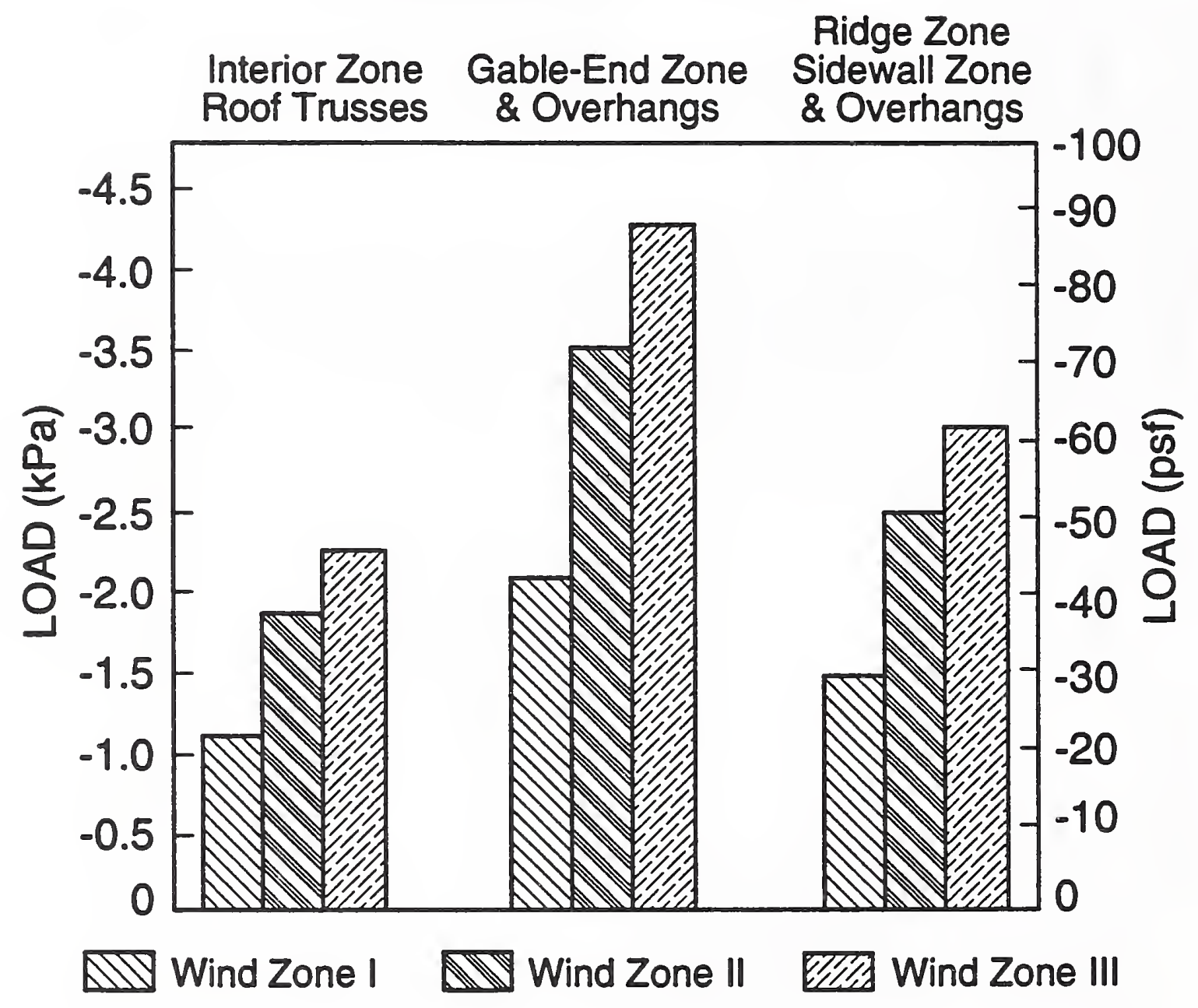

Figure 15. Design wind loads for roof components and cladding - HUD Proposed Rule. 


\section{Components \& Cladding Walls}

Wall studs in sidewalls and endwalls, exterior glazing, exterior coverings and fastenings

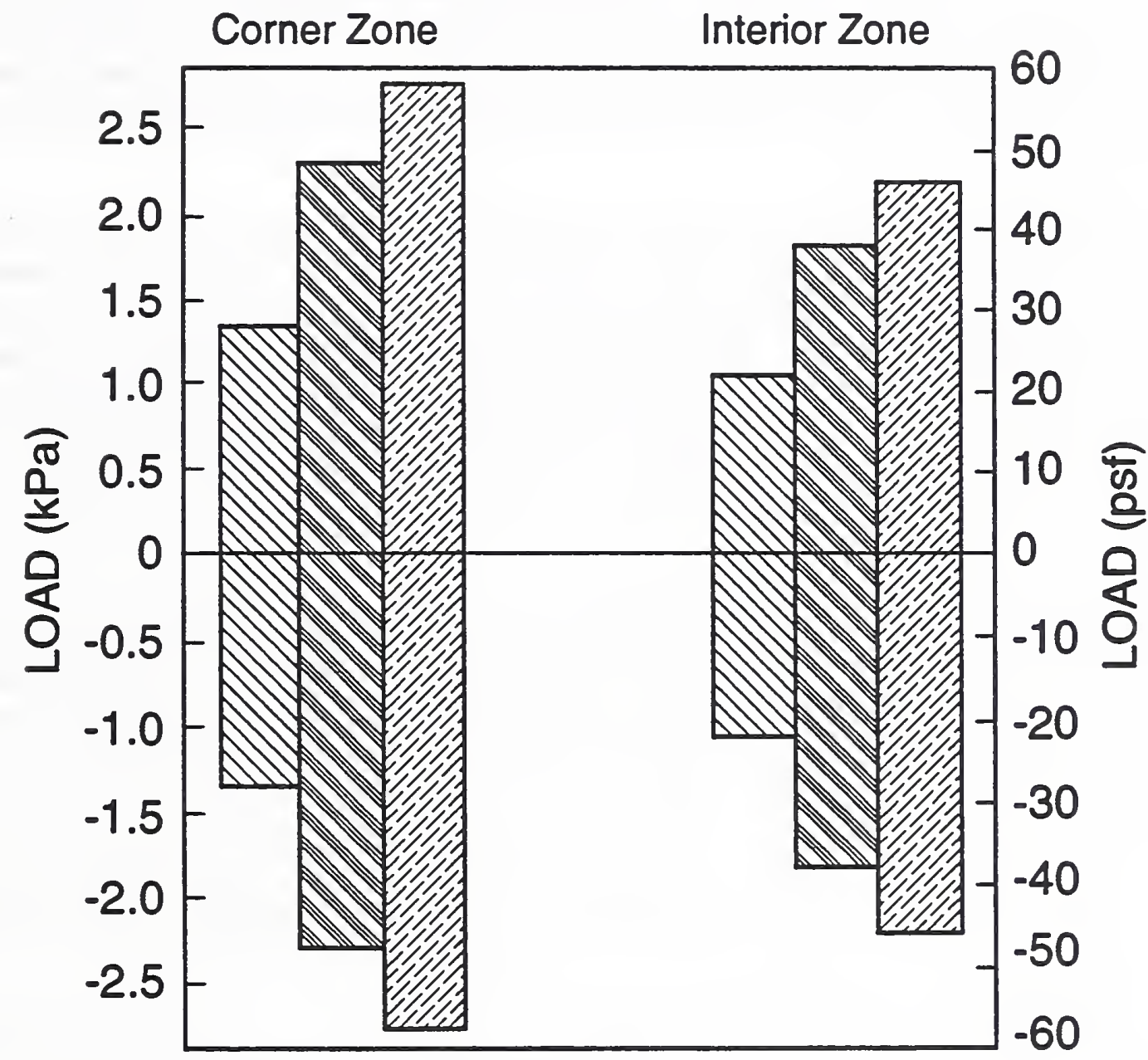

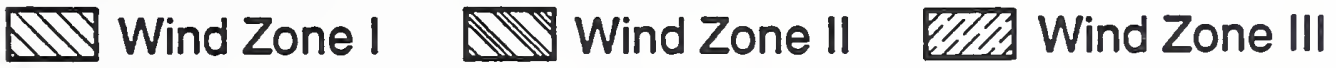

Figure 16. Design wind loads for wall components and cladding - HUD Proposed Rule. 
- The percentage of openings in one wall does not exceed the sum of percentages of openings in the remaining walls and roof surfaces by 5 percent or more, and the percentage of openings in any one of the remaining walls or roof does not exceed 20 percent.

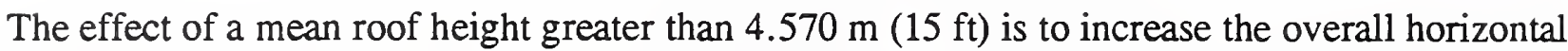
drag and uplift loads and to increase the localized pressures acting on roof elements. The effect

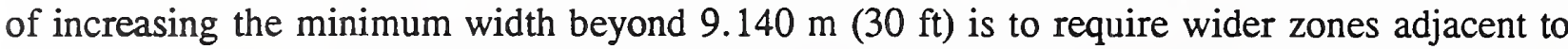
corners of walls and along the roof perimeter and ridge where the largest negative (suction) pressures are assumed to act. In Table 7, the width of these zones has been taken to be $915 \mathrm{~mm}$ $(3 \mathrm{ft})$ which is the minimum allowable value. The effect of roof slopes outside the indicated range is to either increase or decrease the pressures acting on various zones of the roof. In particular, roof slopes of less than 10 degrees will result in larger negative (suction) pressures at the corner zones of the roof.

The wind loads listed in Table 7 and acting in the zones defined in Figure 13 are based on the assumption that the size and distribution of openings in the building envelope satisfy the limitations stated above. Thus, the internal pressures are based on $\mathrm{GC}_{\mathrm{PI}}= \pm 0.25$. If these limitations do not apply, then the range of $\mathrm{GC}_{\mathrm{PI}}$ becomes -0.25 to +0.75 and the effect is to increase the net loads on roof and wall elements in those zones that normally experience negative external pressures. Implicit in the use of $\mathrm{GC}_{\mathrm{PI}}= \pm 0.25$ is the design of openings such as doors and windows to the same level of reliability as other elements of the building envelope.

\subsection{Review of Proposed Design Wind Loads}

As noted earlier, the design wind loads listed in Table 7 are based on velocity pressures of 0.78 , 1.35 and $1.64 \mathrm{kPa}(16.38,28.22$ and $34.15 \mathrm{psf})$ for Zones I, II and III, respectively. Because the design wind loads for the three zones are in direct proportion to these velocity pressures, it will suffice to address only the Zone III values which are based on the calculations presented in the Appendix under the heading of ASCE 7-88. For a mean roof height of $4.570 \mathrm{~m}(15 \mathrm{ft})$ or less, the value of $K_{h}=0.8$ and the corresponding velocity pressure becomes $q_{h}=1.31 \mathrm{kPa}$ (27.32 psf). The prescribed design wind loads are discussed in the order in which they appear in Table 7, and reference is made to the wind loads summarized in Table 6 and the wind load calculations provided in the Appendix under the heading of ASCE 7-88.

\subsubsection{Anchorage for Lateral \& Vertical Stability:}

\section{Horizontal Drag:}

The stability calculations included in the Appendix show a positive pressure of $1.38 \mathrm{kPa}(28.85$ psf) on the windward wall and a negative pressure of $-0.86 \mathrm{kPa}(-18.03 \mathrm{psf})$ on the leeward wall. The combined effect is a net horizontal load of $2.24 \mathrm{kPa}(46.88 \mathrm{psf})$. For convenience of the user, this load is represented in Table 7 by an envelope value of $\pm 2.25 \mathrm{kPa}( \pm 47 \mathrm{psf}$ ) with the implication that the entire load is to be applied either to the windward wall as a positive 
pressure, or to the leeward wall as a negative pressure. For calculating stability against sliding or overturning, either representation is acceptable. However, the user should be aware that the actual loading condition consists of a windward and leeward component.

The aspect ratio (length/width) of the manufactured home described in the Appendix is large $(66 / 14=4.71)$ when compared with aspect ratios of typical wind tunnel building models (generally < 3) that are the basis for the pressure coefficients in ASCE 7-88. It is of interest, therefore, to compare the drag load requirements of ASCE 7-88 with measurements obtained from a full-scale manufactured home with low-slope roof in the natural wind (Marshall 1977).

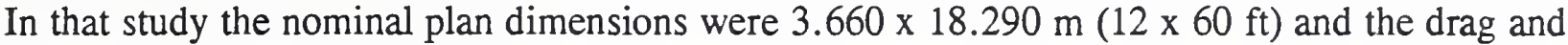
uplift forces were measured by means of instrumented force links. When adjusted for a basic wind speed of $49.2 \mathrm{~m} / \mathrm{s}$ (110 mph), the drag force coefficients yield a drag load of $2.11 \mathrm{kPa}$ (44 psf). This compares favorably with the drag load of $2.24 \mathrm{kPa}$ (46.88 psf) obtained from ASCE 7-88.

\section{Uplift:}

From Table 6 and the Appendix, the uplift loads are $-1.55 \mathrm{kPa}(-32.46 \mathrm{psf})$ on the windward roof slope and $-1.21 \mathrm{kPa}(-25.24 \mathrm{psf})$ on the leeward slope. According to the requirements of ASCE 7-88, these loads apply for roof slopes of from 10 to 15 degrees. As the roof slope is increased to 30 degrees, the load on the leeward slope remains constant, but the load on the windward slope reduces to $-0.35 \mathrm{kPa}(-7.21 \mathrm{psf})$. The uplift loads are represented in Table 7 by the envelope value of $-1.53 \mathrm{kPa}(-32 \mathrm{psf})$. The effect of applying this symmetrical loading condition to roof slopes over the range of 10 to 30 degrees is to overestimate the resultant uplift force and overturning moment while underestimating the horizontal drag force acting on the roof structure. Nevertheless, the advantages of this simplified representation of uplift load probably outweigh those of a more complex loading requirement. In the full-scale measurements noted above, the corresponding uplift load was $-1.77 \mathrm{kPa}(-37 \mathrm{psf})$. However, the roof was arched with a rise-to-span ratio of approximately 0.05 .

\subsubsection{Main Wind Force Resisting System:}

\section{Shearwalls, Diaphragms, etc.:}

For the design of shearwalls and diaphragms that make up the MWFRS, Table 7 requires a load of $\pm 2.25 \mathrm{kPa}$ ( $\pm 47 \mathrm{psf}$ ), the same load as required for horizontal drag when evaluating overall stability. While this loading requirement is generally satisfactory for the design of shearwalls and diaphragms which collect the resultant lateral loads and transfer them to the floor system, it is a loading condition that physically does not occur on either the windward or leeward wall. It is not a load representation that should be used to evaluate the load effect on a moment frame, for example. Nor should it be used for the design of that part of a MWFRS that receives its load from one wall alone. In such cases the exterior loads would need to be correctly distributed between windward and leeward walls, and the effects of internal pressure would need to be included. 


\section{Ridge Beams and Other Main Roof Support Beams:}

For ridge beams and other main roof support beams that make up the MWFRS, it is necessary to include the effect of internal pressure when calculating the uplift load. With a positive internal pressure, the net loads on the windward and leeward roof slopes are $-1.88 \mathrm{kPa}(-39.29$ psf) and $-1.54 \mathrm{kPa}(-32.07 \mathrm{psf})$, respectively. For simplicity, these loads are represented in Table 7 as a uniform load of $-1.72 \mathrm{kPa}(-36 \mathrm{psf})$. Note, however, that for a roof slope of 30 degrees the load on the windward slope becomes $-0.67 \mathrm{kPa}(-14.04 \mathrm{psf})$. As will be discussed later, the simplifying assumption of a symmetrical uplift load can underestimate the load effect on components such as roof trusses.

\subsubsection{Components and Cladding - Roofs:}

For the design of components and cladding, ASCE 7-88 zones the roof and walls in recognition of the fact that aerodynamic effects are highly localized and cannot be generalized for the entire building envelope. Within these zones the magnitudes of the pressures acting on the exterior surfaces of the building are dependent upon the surface area over which they are averaged. Thus, selection of the appropriate design load depends upon the pressure zone designation and the extent of the tributary area from which the component or element in question receives its load. For gable roofs with slopes ranging from 10 to 30 degrees, ASCE 7-88 specifies two pressure zones, an interior zone and a perimeter zone whose width, for the range of building dimensions considered here, is $915 \mathrm{~mm}$ ( $3 \mathrm{ft}$ ). In addition to the edges of the roof, the perimeter zone includes a $915 \mathrm{~mm}(3 \mathrm{ft})$ wide strip along each side of the ridge line.

\section{Roof Trusses:}

Although roof structures designed to act as diaphragms constitute a part of the MWFRS, individual roof trusses are considered to be secondary members or components. Consequently, their design loads should accommodate the requirements for the design of components and cladding. In developing the design load requirement for roof trusses, there are three important considerations: First, the width of a rectangular tributary area need not be less than $1 / 3$ its length. Second, when tributary areas involve more than one pressure zone, an equivalent areaweighted average load may be used. Third, loads for the design of components and cladding are envelope (worst case) values and, therefore, not all portions of a tributary area involving more than one zone experience maximum loads for a given wind direction. Thus, the windward half of a roof truss can be loaded consistent with the requirements for components and cladding while the leeward half would be subjected to loads consistent with the requirements for design of the MWFRS. Alternatively, both roof slopes can be loaded consistent with the MWFRS design loads.

For roof slopes ranging from 10 to 30 degrees, truss spans of 4.270 and $8.530 \mathrm{~m}$ ( 14 and $28 \mathrm{ft}$ ), and positive internal pressure, the following load combinations are among the possibilities: 
Loading for Windward Slope Based on Components \& Cladding Loads and Loading for Leeward Slope Based on MWFRS Loads:

Truss Located Outside Gable-End Edge Strip (see Appendix for calculations):

$\begin{array}{lrrrr}\text { Span } & 4.270 \mathrm{~m}(14 \mathrm{ft}) & & 8.530 \mathrm{~m}(28 \mathrm{ft}) \\ & & & & \\ \text { Load } & \mathrm{kPa} & (\mathrm{psf}) & \mathrm{kPa} & (\mathrm{psf}) \\ \text { Windward slope } & -2.83 & (-59.01) & -2.11 & (-43.99) \\ \text { Leeward slope } & -1.54 & (-32.07) & -1.54 & (-32.07)\end{array}$

Truss Located Within Gable-End Edge Strip:

$\begin{array}{lllll}\text { Windward slope } & -3.96 & (-82.78) & -2.89 & (-60.38) \\ \text { Leeward slope } & -1.54 & (-32.07) & -1.54 & (-32.07)\end{array}$

Loading for Windward and Leeward Slopes Based on MWFRS Design Loads:

Roof Slope $=10$ to 15 degrees

\begin{tabular}{lrlrl} 
Span & \multicolumn{2}{c}{$4.270 \mathrm{~m}(14 \mathrm{ft})$} & $8.530 \mathrm{~m}(28 \mathrm{ft})$ \\
& & & & \\
Load & $\mathrm{kPa}$ & $(\mathrm{psf})$ & $\mathrm{kPa}$ & $(\mathrm{psf})$ \\
Windward slope & -1.88 & $(-39.29)$ & -1.88 & $(-39.29)$ \\
Leeward slope & -1.54 & $(-32.07)$ & -1.54 & $(-32.07)$
\end{tabular}

Roof Slope $=30$ degrees

$\begin{array}{lllll}\text { Windward slope } & -0.67 & (-14.04) & -0.67 & (-14.04) \\ \text { Leeward slope } & -1.54 & (-32.07) & -1.54 & (-32.07)\end{array}$

These loads are represented in Table 7 by an envelope value of $-2.25 \mathrm{kPa}(-47 \mathrm{psf})$ with the

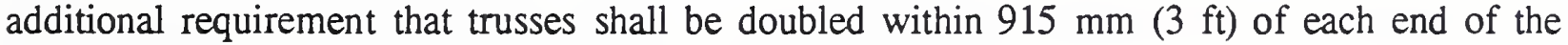
roof. Although the worst-case loading on the windward slope of a $4.270 \mathrm{~m}(14 \mathrm{ft}) \mathrm{span}$ exceeds the envelope value of Table 7 ( -2.83 vs. $-2.25 \mathrm{kPa}$ ( -59.01 vs. $-47 \mathrm{psf})$ ), the span-averaged load is consistent with the load requirement of Table 7 . However, the unbalanced truss load for this same loading condition (-2.83 vs. $-1.54 \mathrm{kPa}(-59.01$ vs. $-32.07 \mathrm{psf}))$ is not addressed in Table 7. If the loads of Table 7 for the interior and eaves pressure zones of the roof are used in place

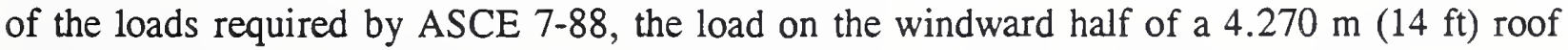
truss becomes $-2.54 \mathrm{kPa}(-53 \mathrm{psf})$, and the difference between windward and leeward loads becomes $1.01 \mathrm{kPa}(21 \mathrm{psf})$. 


\section{Exterior Roof Coverings and Fastenings:}

According to the calculations provided in the Appendix and summarized in Table 6, the range of design loads for the interior zone of the roof is $-2.03 \mathrm{kPa}(-42.35 \mathrm{psf})$ to $-1.77 \mathrm{kPa}(-36.88$ psf) with the tributary area ranging from 0.93 to $9.29 \mathrm{~m}^{2}$ (10 to $\left.100 \mathrm{ft}^{2}\right)$. For the perimeter (edge) zone, the corresponding range is $-4.25 \mathrm{kPa}(-88.79 \mathrm{psf})$ to $-2.94 \mathrm{kPa}(-61.47 \mathrm{psf})$. For the design of roof coverings and fastenings, Table 7 requires design loads of $-2.25 \mathrm{kPa}(-47 \mathrm{psf})$ and $-4.26 \mathrm{kPa}(-89 \mathrm{psf})$ for the interior and perimeter zones, respectively, regardless of the actual tributary area involved. These loads are in reasonable agreement with the ASCE 7-88 requirements for tributary areas of $0.93 \mathrm{~m}^{2}\left(10 \mathrm{ft}^{2}\right)$ or less.

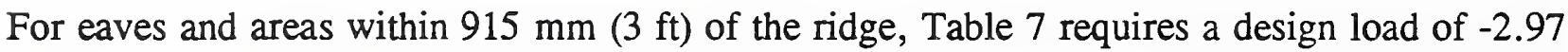
$\mathrm{kPa}$ (-62 psf). However, since Table 7 specifically addresses "Eaves (overhangs at sidewalls)," the 4th entry under "Components and Cladding" apparently is intended to mean the roof perimeter zone above the sidewall and the ridge zone. ASCE 7-88 requires a loading of -4.25 $\mathrm{kPa}(-88.79 \mathrm{psf})$ for a tributary area of $0.93 \mathrm{~m}^{2}\left(10 \mathrm{ft}^{2}\right)$ or less located within these zones. For the loads plotted in Figure 15, it has been assumed that Table 7 requires $-4.26 \mathrm{kPa}(-89 \mathrm{psf})$ for the perimeter zone at gable ends and $-2.97 \mathrm{kPa}(-62 \mathrm{psf})$ for the perimeter zone at sidewalls and for the ridge zones.

\section{Overhangs:}

For the design of overhangs, ASCE 7-88 distinguishes between load effects on the MWFRS and load effects on components and cladding. From Table 6 and the Appendix, the load effect on the MWFRS is $-2.94 \mathrm{kPa}$ (-61.31 psf) for sidewalls (wind normal to the ridge) and $-2.59 \mathrm{kPa}$ $(-54.09 \mathrm{ps}$ ) for endwalls (wind parallel to the ridge). For components and cladding, the load effect at sidewalls and at endwalls is $-3.93 \mathrm{kPa}(-81.96 \mathrm{psf})$ for tributary areas of $0.93 \mathrm{~m}^{2}(10$ $\left.\mathrm{ft}^{2}\right)$ or less, and $-2.61 \mathrm{kPa}(-54.64 \mathrm{psf})$ for tributary areas of $9.29 \mathrm{~m}^{2}\left(100 \mathrm{ft}^{2}\right)$ or greater. Under the general heading of Components and Cladding, Table 7 requires design loads of $-2.97 \mathrm{kPa}$ ( $-62 \mathrm{psf}$ ) for overhangs at sidewalls and $-4.26 \mathrm{kPa}(-89 \mathrm{psf})$ for overhangs at endwalls or gable ends.

\subsubsection{Components and Cladding - Walls:}

ASCE 7-88 defines two wall pressure zones for the design of components and cladding. Corner zones provide for the intense negative pressures associated with flow separation at these locations and, for the range of building dimensions being considered here, these zones have a width of $915 \mathrm{~mm}$ (3 ft). All other wall areas are designated as interior zones. For tributary areas of 0.93 $\mathrm{m}^{2}\left(10 \mathrm{ft}^{2}\right)$ or less within a corner zone, the ASCE 7-88 design loads are $2.16 \mathrm{kPa}$ (45.08 psf) and $-2.94 \mathrm{kPa}(-61.47 \mathrm{psf})$. When the entire zone is treated as a tributary area (approximately $2.32 \mathrm{~m}^{2}\left(25 \mathrm{ft}^{2}\right)$ in this case) the design loads are $2.03 \mathrm{kPa}(42.35 \mathrm{psf})$ and $-2.68 \mathrm{kPa}(-56.01$ psf). In Table 7, the design of components and cladding located within corner zones is based on loads of $\pm 2.78 \mathrm{kPa}( \pm 58 \mathrm{psf})$. 
For the design of wall studs, the tributary area should be taken as $\mathrm{L}^{2} / 3$, where $\mathrm{L}$ is the stud length. Approximately, this tributary area is equal to the assumed corner zone area of $2.32 \mathrm{~m}^{2}$ $\left(25 \mathrm{ft}^{2}\right)$. Therefore, it is reasonable to include wall studs in the required design load for exterior glazing and wall coverings in the corner zone as is the case with Table 7.

For interior zones of walls, ASCE 7-88 requires design loads of $2.16 \mathrm{kPa}$ (45.08 psf) and -2.29 $\mathrm{kPa}(-47.81 \mathrm{psf})$ for tributary areas of $0.93 \mathrm{~m}^{2}\left(10 \mathrm{ft}^{2}\right)$ or less. For tributary areas equal to or greater than $46.45 \mathrm{~m}^{2}\left(500 \mathrm{ft}^{2}\right)$, the design loads are $1.64 \mathrm{kPa}(34.15 \mathrm{psf})$ and $-1.77 \mathrm{kPa}(-36.88$ psf). The corresponding load range specified in Table 7 for interior zones of walls is \pm 2.20 $\mathrm{kPa}$ ( $\pm 46 \mathrm{psf})$. The ASCE 7-88 design loads for wall studs are 2.03 and $-2.17 \mathrm{kPa}$ (42.35 and $45.35 \mathrm{psf})$, based on a tributary area of approximately $2.32 \mathrm{~m}^{2}\left(25 \mathrm{ft}^{2}\right)$. Table 7 requires design loads of $\pm 2.20 \mathrm{kPa}$ ( $\pm 46 \mathrm{psf}$ ) for this case.

For components whose tributary area may differ from the tributary areas considered herein, the net loads (combined internal and external pressures) may be obtained by linear interpolation between the values listed Table 8 .

Table 8. Net Loads for Tributary Areas Located in Wall Interior Zone (ASCE 7-88)

Tributary Area Net Load
$\mathrm{m}^{2} \quad\left(\mathrm{ft}^{2}\right)$
$\mathrm{kPa}$
(psf)

$\begin{array}{rrrr}0.93 & (10) & -2.29,+2.16 & (-47.8,+45.1) \\ 2.32 & (25) & -2.17,+2.03 & (-45.4,+42.4) \\ 4.65 & (50) & -2.07,+1.94 & (-43.2,+40.4) \\ 9.29 & (100) & -1.99,+1.86 & (-41.5,+38.8) \\ 18.6 & (200) & -1.90,+1.75 & (-39.6,+36.6)\end{array}$

\subsubsection{Components and Cladding - Bottom Board:}

In Section 3.3.3 of this document it was noted that non-structural bottom boards tend to fail when exposed to the direct action of the wind, either because of skirting not being installed or because of skirting being removed by the wind. This item is not addressed in Table 7 and, in view of the fact that no definitive test data are available, the ASCE 7-88 minimum requirement of $\pm 0.48 \mathrm{kPa}$ ( $\pm 10 \mathrm{psf}$ ) for the design of components and cladding should be specified for bottom boards. However, this loading condition should not be included when calculating overall uplift and stability. 


\subsection{The Significance of Internal Pressures}

In Section 5.2 it was noted that the internal pressures are based on $\mathrm{GC}_{\mathrm{PI}}= \pm 0.25$. Although internal pressures have no effect on the overall horizontal drag or uplift forces, they do influence the loads for design of the main wind force resisting system (MWFRS) and for the design of components and cladding. For buildings with mean roof height equal to or less than $4.570 \mathrm{~m}$ $(15 \mathrm{ft})$, the contribution of the internal and external pressures to the design forces is in direct proportion to the respective pressure coefficients. Thus, for the design of ridge beams and other main roof support beams in wind Zone III where the specified design load is $-1.72 \mathrm{kPa}(-36 \mathrm{psf})$ (average of windward and leeward roof loads - see Appendix), the contribution of the internal pressure is $(0.25) /[(0.9+0.7) / 2+0.25]=0.25 / 1.05=24$ percent. If the building envelope contains a major opening (see Section 5.2), then the contribution of the internal pressure becomes $(0.75) /[(0.9+0.7) / 2+0.75]=0.75 / 1.55=48$ percent, and the required design load is increased by $(1.55-1.05) / 1.05=43$ percent. Similar increases occur for the design of components and cladding. Therefore, direct benefits in the form of reduced design loads can result from ensuring the integrity of the building envelope in wind storms.

\subsection{Summary and Recommendations}

In this chapter, the design wind forces of the HUD Proposed Rule (Table 7) have been compared with detailed load calculations based on the wind load requirements of ASCE 7-88. In general, the proposed design loads are consistent with the ASCE 7-88 requirements, but there are some exceptions. Specifically, the horizontal load requirement of $\pm 2.25 \mathrm{kPa}$ ( $\pm 47 \mathrm{psf}$ ) for the design of shearwalls, diaphragms and their fastening and anchorage systems is inconsistent with the actual load distribution between windward and leeward walls as is indicated in Table 6. While this simplified loading requirement may be satisfactory for certain specific structural systems, there are other systems to which it does not apply. For tributary areas of $0.93 \mathrm{~m}^{2}\left(10 \mathrm{ft}^{2}\right)$ or less and located within $915 \mathrm{~mm}(3 \mathrm{ft}$ ) of the sidewalls (eaves) or ridge line, ASCE 7-88 requires a design load of $-4.25 \mathrm{kPa}(-88.8 \mathrm{psf})$ while Table 7 requires $-2.97 \mathrm{kPa}(-62 \mathrm{psf})$. For the design of overhangs at sidewalls, ASCE $7-88$ requires $-3.93 \mathrm{kPa}(-82.0 \mathrm{psf})$ while Table 7 requires $-2.97 \mathrm{kPa}(-62 \mathrm{psf})$.

Finally, there appears to be an inconsistency in Table 7 regarding design loads for exterior roof coverings and fastenings within $915 \mathrm{~mm}$ ( $3 \mathrm{ft}$ ) of each end and edge of the roof and at the eaves (roof perimeter at sidewalls).

Based on this review of the HUD Proposed Rule, the following changes to Table 7 are recommended:

- Modify the horizontal loads for design of the main wind force resisting system to make them consistent with the actual load distribution between windward and leeward walls as is indicated in Table 6 and in the Appendix. Note that this modification will not increase the required design load. 
o Clarify 3rd and 4th entries under Components and Cladding in Table 7.

o Add a minimum design load requirement of $\pm 0.48 \mathrm{kPa}$ ( $\pm 10 \mathrm{psf}$ ) applied to bottom boards of manufactured homes.

o Add a footnote to Table 7 stating that the design wind loads apply to manufactured homes with mean roof height of not more than $4.6 \mathrm{~m}(15 \mathrm{ft})$ and roof slopes in the range of 10 to 30 degrees. 


\subsection{MAJOR FINDINGS AND RECOMMENDATIONS}

\subsection{General}

In the wake of widespread damage to manufactured homes in south Florida during the passage of Hurricane Andrew, NIST has undertaken a review of the MHCSS wind load provisions at the request of HUD. This review has involved the assessment of wind speeds in Hurricane Andrew during and after landfall, a study of selected post-disaster reports on wind damage to manufactured homes and conventional wood-framed dwellings in the affected area, a review of the wind load provisions of relevant codes and standards, and an assessment of design wind loads contained in the HUD Proposed Rule. Major findings and recommendations resulting from this review are presented here.

\subsection{Major Findings}

\section{Wind Speeds:}

- Hurricane Andrew made landfall between Key Biscayne and Key Largo at approximately 0900 GMT (0500 LDT) on Monday, August 24, 1992. The maximum sustained wind speed over water has been estimated by the National Hurricane Center at $64.4 \mathrm{~m} / \mathrm{s}(144 \mathrm{mph})$ which corresponds to a category 4 hurricane on the Saffir-Simpson scale. There were no confirmed sightings of tornadoes in Dade County and post-disaster inspections have produced no evidence of tornado damage.

- No anemometers exposed to winds in the eyewall of Andrew survived long enough or had the recording capability to register the maximum wind speeds. The highest recorded gust speed, corrected for calibration error, was $79.1 \mathrm{~m} / \mathrm{s}$ (177 mph) at Perrine. It is possible that slightly higher gust speeds occurred near the inner edge of the eyewall where conditions are favorable for the development of intense but highly localized gust speeds, and post-storm observations tend to confirm this.

- Upper-bound estimates of fastest-mile wind speeds were obtained from computerbased models and analyses incorporating both surface and flight-level wind speed records. In the area of heaviest damage, estimates of fastest-mile wind speeds range from $54.5 \mathrm{~m} / \mathrm{s}(122 \mathrm{mph})$ at Florida City to $64.8 \mathrm{~m} / \mathrm{s}(145 \mathrm{mph})$ at the Burger King Headquarters Building near where the northern sector of the eyewall crossed the coastline. In the Tamiami Airport/Country Walk area, fastest-mile speeds are estimated to have been approximately $60.3 \mathrm{~m} / \mathrm{s}(135 \mathrm{mph})$. Wind speed records recently obtained from the FAA suggest fastest-mile wind speeds of 35.8 to $38.0 \mathrm{~m} / \mathrm{s}$ ( 80 to $85 \mathrm{mph}$ ) at Miami International Airport. Gust speeds can be estimated by multiplying the fastest-mile speeds by a factor of from 1.15 to 1.20 . 
Wind Damage to Traditional Wood-Framed Dwellings:

o Roofing systems suffered heavy damage over a wide area along the storm track. The failure of roof tiles, which were not mechanically fastened, created a source of missiles that caused window breakage in adjacent structures. Window breakage, garage door failures, and inadequate fastening of window and door frames resulted in the pressurization of building interiors and additional structural damage as well as water damage.

o The blow-off of roof sheathing, perimeter sheathing at gable ends in particular, resulted in the loss of diaphragm action of roof structures and the progressive failure of roof trusses. Much of this damage is directly attributable to improper installation of sheathing fasteners and disregard for the fastener schedules required by the South Florida Building Code. Where they were properly installed, tiedown straps were effective in transferring uplift loads from roof trusses to walls.

o Many instances of gable-end wall failures were observed. In large part, these failures were due to inadequate connections and the lack of lateral support or bracing that should have been provided by ceilings designed to act as diaphragms.

\section{Wind Damage to Manufactured Housing:}

- In Dade County, more than 5,000 manufactured homes were destroyed or were rendered uninhabitable by Hurricane Andrew. Of this total, approximately 67 percent are believed to have been HUD-labeled units.

- As with conventional residential construction, the failure of roofing systems was widespread. Failures of metal roof coverings resulted from loss of attachment at the sidewalls, and instances were noted where entire rows of sheathing fasteners had missed the roof truss. Failures of truss-to-wall connections were observed in which staple crowns had pulled through the uplift strap.

- The failure of wall panels and fasteners, particularly on metal-clad units, was a common occurrence on endwalls and in areas adjacent to corners where flow separation leads to intense negative (suction) pressures. Interlocking seams in metal and vinyl lap siding were prone to separation and opening when these materials were installed without the support of wall sheathing. These failures exposed the wall cavity and interior wall covering to the action of wind and water.

- In Florida, almost all of the units inspected had some anchoring system installed and these systems generally performed adequately outside the area of highest winds. For areas near to or within the eyewall, failures of $610 \mathrm{~mm}(2 \mathrm{ft})$ helical 
anchors and rock anchors were observed. In many instances where tiedown straps were attached only to the underframe, the superstructure of the home was cleanly removed by the wind.

- In general, HUD-labeled units suffered less damage than did pre-HUD units. However, conventional residential construction located near manufactured home parks performed significantly better than did the manufactured homes, including HUD-labeled units.

Based on the damage assessments (referenced herein) conducted at manufactured home parks located inside and beyond the radius of maximum winds, and based on the upper-bound estimates of wind speeds at those locations, it appears that HUD-labeled units began to experience damage to roof and wall coverings at fastest-mile speeds of up to $42.5 \mathrm{~m} / \mathrm{s}(95 \mathrm{mph})$ while many pre-HUD units suffered major structural damage. At wind speeds of from 44.7 to $53.6 \mathrm{~m} / \mathrm{s}(100$ to $120 \mathrm{mph}$ ), many HUD-labeled units suffered significant structural damage. At wind speeds ranging from 53.6 to $60.3 \mathrm{~m} / \mathrm{s}$ (120 to $135 \mathrm{mph})$ there were numerous instances of HUD-labeled units suffering total destruction.

\section{Design Wind Loads:}

- Based on the wind load provisions of ASCE 7-88, the basic wind speed (fastestmile speed at $10 \mathrm{~m}$ (32.8 ft) in flat, open country) for the area of heaviest damage in Hurricane Andrew is $49.2 \mathrm{~m} / \mathrm{s}(110 \mathrm{mph})$, and the corresponding design wind speed is $51.9 \mathrm{~m} / \mathrm{s}(116 \mathrm{mph})$.

- For load and resistance factor design (LRFD), ASCE 7-88 requires a load factor of 1.3 for wind, and the corresponding fastest-mile wind speed at the strength limit state is $59.0 \mathrm{~m} / \mathrm{s}(132 \mathrm{mph})$. As a consequence, much of the damage resulting from Hurricane Andrew must be attributed to factors other than exceptionally high wind speeds.

- The horizontal drag and uplift forces required by the MHCSS correspond to basic wind speeds of 35.8 to $38.0 \mathrm{~m} / \mathrm{s}$ ( 80 to $85 \mathrm{mph}$ ), and the design loads for components and cladding range from 55 to 73 percent of the corresponding ASCE 7-88 loads. The MHCSS requirements do not account for negative (suction) pressures on walls.

o The $53.6 \mathrm{~m} / \mathrm{s}$ (120 mph) design wind speed requirement of SFBC-88 is, in effect, a gust speed and the equivalent basic wind speed is $46.0 \mathrm{~m} / \mathrm{s}(103 \mathrm{mph})$. The drag and uplift forces required by SFBC- 88 for structural stability correspond to basic wind speeds of 40.7 and $43.8 \mathrm{~m} / \mathrm{s}$ (91 and $98 \mathrm{mph}$ ), respectively. Loads for the design of components and cladding are 63 to 88 percent of the corresponding ASCE 7-88 values. 
o Although SBC-91 and ASCE 7-88 reference the same basic wind speeds and incorporate much of the same pressure coefficient data, the SBC-91 load requirements are approximately 75 percent of the those of ASCE 7-88 for the same wind exposure. In large part, this difference results from a reduction factor of 0.8 applied to the SBC-91 pressure coefficients and disregard for the fact that the wind speed probability distributions for hurricanes and extratropical storms are different.

- Although the MHI proposed wind load requirements are based on the provisions of SBC-91, simplification of the MHI loading requirements by combining pressure zones results in design loads for the MWFRS and cladding that generally are higher than the corresponding SBC-91 loads. An exception is the load requirement for the roof edge zone at gable ends.

o In addition to qualifying as a true consensus standard, ASCE 7-88 accounts for the multi-directional character of hurricane winds and the fact that the probability distribution of extreme winds in hurricanes differs from that for extratropical storms.

\subsection{Recommendations}

The following recommendations are based on the documents reviewed in the course of this study and on the major findings summarized above.

- The wind load provisions of ASCE Standard 7-88 should be the basis for upgrading and improving the current wind load requirements of the Manufactured Housing Construction and Safety Standards (MHCSS).

- The draft wind load requirements of the HUD Proposed Rule could benefit from additional refinement. Specifically, the horizontal loads specified for the design of the main wind force resisting system (MWFRS) should be revised to make them consistent with the actual load distribution between windward and leeward walls.

- The 3rd and 4th entries under Components and Cladding in Table 7 need to be clarified.

- The HUD Proposed Rule should include a minimum requirement of $\pm 0.48 \mathrm{kPa}$ ( $\pm 10 \mathrm{psf}$ ) for the design of bottom boards.

- A footnote needs to be added to Table 7 stating that the design wind loads apply

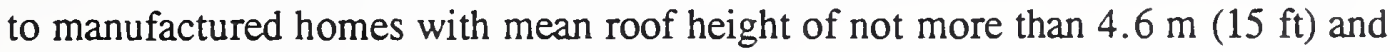
roof slopes in the range of 10 to 30 degrees. 
- This study has addressed only the load side of the design equation. In the interest of safety and economy, the prescriptive requirements of the HUD Proposed Rule should be consistent with the specified design loads, and the testing and analysis required to assure this consistency should be carried out. 


\subsection{REFERENCES}

American Society of Civil Engineers (1990). "Minimum Design Loads for Buildings and Other Structures." ASCE 7-88, 94 pp.

Davenport, A.G. (1977). "The Prediction of Risk Under Lateral Loading." Proceedings, ICOSSAR Conference, Technical University of Munich.

Davenport, A.G. and Surry, D. (1979). Note on Effective Wind Gust Pressure Coefficients for Design of Low-Rise Buildings, Boundary Layer Wind Tunnel Laboratory, The University of Western Ontario, London, Ontario, Canada.

Dept. of Housing and Urban Development (1993). Proposed Rule on Wind Standards, Manufactured Home Construction and Safety Standards, Federal Register, Vol. 58, No. 70, Part VI.

Douglas, B.K. (1992a). "Hurricane Andrew, Part 1, Wood Building Performance and Analysis." Special Report of the National Forest Products Association, November, 15 pp.

Douglas, B.K. (1992b). "Hurricane Andrew, Part 2, Wood Building Analysis and Recommendations." Special Report of the National Forest Products Association, November, 15 pp.

Durst, C.S. (1960). Wind Speeds Over Short Periods of Time." Meteor. Mag., 89, pp 181187.

Federal Emergency Management Agency (1992). "Building Performance: Hurricane Andrew in Florida." FIA 22, Federal Emergency Management Agency/Federal Insurance Administration, December, 93 pp.

Ferguson, E.A. and Cardwell, F. (1992). "Hurricane Andrew, Monday, August 24, 1992, South Florida - Dade County." Report prepared for Manufactured Housing Institute, Compliance Systems Publications, Inc., Atlanta, GA, October 22, 24 pp.

Florida Manufactured Housing Association, Inc. (1993). Summary of Homes Destroyed, Dade County Parks - Hurricane Andrew. Florida Manufactured Housing Association, Inc., Tallahassee, FL, 1 pp.

Keith, E.L. and Rose, J.D. (1992). "Hurricane Andrew, Structural Performance of Buildings in Southern Florida, August 24, 1992." American Plywood Association, Tacoma, Washington, APA Report T92-21, September, 72 pp.

Korman, R. et al. (1993). "Andrew's Devastation of South Florida Tests the Capacity to Correct Human Blunders." ENR, Vol. 230, No. 5, pp 26-30. 
Krayer, W.R. and Marshall, R.D. (1992). "Gust Factors Applied to Hurricane Winds." Bulletin, American Meteorology Society, Vol. 73, No. 5, pp 613-617.

"Manufactured Home Construction and Safety Standards." (1992). 24 CFR, Chapter XX, Pt. 3280, pp 196-223.

Manufactured Housing Institute (1992). "MHI Proposed New Wind Safety Requirements for the HUD Code for Manufactured Homes Based on the Requirements of the Standard Building Code (SBC-91)." Prepared by Manufactured Housing Institute 10-16-92, 14 pp.

Marshall, R.D. (1977). "The Measurement of Wind Loads on a Full-Scale Mobile Home." NBSIR 77-1289, National Bureau of Standards, Gaithersburg, MD, 120 pp.

Marshall, R.D. and Reinhold, T.A. (1981). Discussion of paper, "Effective Wind Loads on Flat Roofs," by T. Stathopoulos et al., Journal of the Structural Division, ASCE, Vol. 108, No. ST2, February, pp 495-498.

Mehta, K.C. (1984). "Wind Load Provisions of ANSI A58.1-1982." Joumal of Structural Engineering, ASCE, Vol. 110, No. 4, pp 769-784.

NCSBCS (1992). "Hurricane Andrew's Effect on Manufactured Housing in Florida and Louisiana." Report prepared by the National Conference of States on Building Codes and Standards, Inc. September 25, revised October 1, 24 pp.

Perry, D.C. et al. (1992). "Hurricane Andrew - Preliminary Observations of WERC Post Disaster Team." Wind Engineering Research Council, Inc., September, 5 pp.

Powell, M.D. and Houston, S. (1993). "Surface Wind Field Analysis in Hurricane Andrew." 20th Conference on Hurricanes and Tropical Meteorology, May 10-14, San Antonio, TX, 4 pp.

"Preliminary Report in Response to Hurricane Andrew, Dade County Florida." (1992). Report by Building Performance Assessment Team, Federal Emergency Management Agency, Federal Insurance Administration, $32 \mathrm{pp}$.

Rappaport, E. (1992). "Preliminary Report, Hurricane Andrew, 16-28 August, 1992." National Hurricane Center, September 16, 28 pp.

Reinhold, T.A., Vickery, P.J. and Powell, M.D. (1992). "Wind Speeds in Hurricane Andrew: Myths and Reality." American Concrete Institute Annual Convention, San Juan, PR, Oct. 26, $12 \mathrm{pp}$ plus figures.

"South Florida Building Code." (1988). 1988 Edition, Volume 1, Building and Zoning Department, Metropolitan Dade County, Miami, FL. 
"Standard Building Code." (1991). 1991 Edition, Southern Building Code Congress International, Inc., Birmingham, AL, pp 285-304.

Tryggvason, B.V. (1979). "Computer Simulation of Tropical Cyclone Wind Effects for Australia." James Cook University of North Queensland, Department of Civil and Systems Engineering, Wind Engineering Report, February.

Vann, W.P. and McDonald, J.R. (1978). "An Engineering Analysis: Mobile Homes in Windstorms." IDR Doc. 32D, Institute for Disaster Research, Texas Tech University, Lubbock, TX.

Zollo, R.F. (1993). "Hurricane Andrew: August 24, 1992, Structural Performance of Buildings in Dade County, Florida." Technical Report No. CEN 93-1, Department of Civil and Architectural Engineering, University of Miami, Coral Gables, FL, March 11, 76 pp.

\section{ACKNOWLEDGMENTS}

For providing many helpful suggestions and numerous reference materials used in this study, the author wishes to thank Mr. William Freeborne of the Affordable Housing Research and Technology Division, Office of Research, Evaluation and Monitoring, and Mr. Richard Mendlen of the Manufactured Housing and Construction Standards Division, Office of Manufactured Housing and Regulatory Functions, U.S. Department of Housing and Urban Development. The author is deeply indebted to Dr. Mark D. Powell of the Hurricane Research Division, Atlantic Oceanographic and Meteorological Laboratory (HRD/AOML/NOAA), for making wind speed records and other data available, and for providing valuable insight concerning wind features during hurricane landfall. For his constructive comments in the course of reviewing this document, the author wishes to thank Dr. Timothy A. Reinhold, Department of Civil Engineering, Clemson University. 



\section{APPENDLX}

\section{COMPARISON OF DESIGN WIND LOADS FROM SELECTED CODES \& STANDARDS}

The calculations which follow are provided in support of the design loads summarized in Table 6 of the text and provide a detailed comparison of the wind load requirements of the codes and standards addressed herein. In addition, calculations are included for certain specific requirements of ASCE 7-88 for roof slopes of 15 and 30 degrees. Figure, table and section numbers referenced herein are consistent with those of the respective codes and standards.

NOTE: Because all codes and standards referred to in this document carry common U.S. units, the calculations included in this appendix are likewise presented in common U.S. units. To aid the reader in converting to SI units, the following equivalents are provided.

Length: $\quad 1$ inch $=2.540 \times 10^{-2}$ meter $(\mathrm{m})$

1 foot $=3.048 \times 10^{-1}$ meter $(\mathrm{m})$

Area: $\quad 1 \mathrm{ft}^{2}=9.290 \times 10^{-2} \operatorname{meter}^{2}\left(\mathrm{~m}^{2}\right)$

Pressure: $\quad 1 \mathrm{lbf} / \mathrm{ft}^{2}(\mathrm{psf})=4.788 \times 10^{1}$ pascal $(\mathrm{Pa})$

Velocity: $\quad 1$ mile per hour $(\mathrm{mph})=4.470 \times 10^{-1}$ meter per $\mathrm{sec}(\mathrm{m} / \mathrm{s})$

\section{ASSUMPTIONS:}

Manufactured home with following dimensions and wind exposure:

Width $=14$ feet

Length $=66$ feet

Eave Height $=10.5$ feet

Roof Slope $=15$ degrees

No major openings in walls or roof

Location $=$ Hurricane-prone coastal zone

Exposure Category C

ASCE 7-88 (Minimum Design Loads for Buildings and Other Structures):

BASIC WIND SPEED:

$\mathrm{V}=110 \mathrm{mph}$ (See Figure 1, ASCE 7-88)

IMPORTANCE FACTOR:

$\mathrm{I}=1.05$ (Table 5) 
VELOCITY PRESSURE EXPOSURE COEFFICIENT:

$$
\mathrm{K}_{\mathrm{z}}=0.80 \text { (Table 6) }
$$

VELOCITY PRESSURE: (Equation 3)

$$
\mathrm{q}_{z}=0.00256 \mathrm{~K}_{\mathrm{z}}(\mathrm{IV})^{2}=27.32 \mathrm{psf}
$$

GUST RESPONSE FACTOR:

$$
\mathrm{G}_{\mathrm{b}}=\mathrm{G}_{\mathrm{z}}=1.32 \text { (Table 8) }
$$

INTERNAL PRESSURE COEFFICIENTS:

Condition I: (Table 9) $\quad \mathrm{GC}_{\mathrm{pi}}= \pm 0.25$

STABILITY OF STRUCTURE: (Table 4 and Figure 2)

$L / B=14 / 66=0.21$

$\mathrm{h}=10.5+(7 / 2)(\tan 15)=11.4$

$\mathrm{h} / \mathrm{L}=11.4 / 14=0.8$

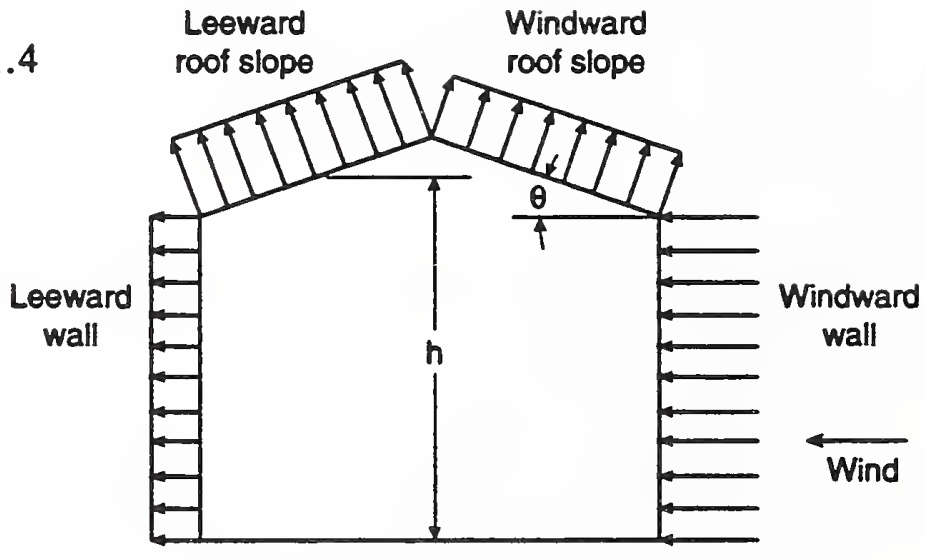

Horizontal Loads on Walls:

Windward Wall:

$$
\mathrm{p}=(27.32)(1.32)(0.8)=28.85 \mathrm{psf}
$$

Leeward Wall:

$$
\mathrm{p}=(27.32)(1.32)(-0.5)=-18.03 \mathrm{psf}
$$

Horizontal Loads on Roof:

Windward Slope:

$$
p=(27.32)(1.32)(-0.9)=-32.46 p s f
$$


Leeward Slope:

$$
\mathrm{p}=(27.32)(1.32)(-0.7)=-25.24 \mathrm{psf}
$$

NET DRAG LOAD:

Walls:

$$
\mathrm{p}=28.85-(-18.03)=46.88 \mathrm{psf}
$$

Roof:

$$
p=-32.46-(-25.24)=-7.22 p s f
$$

Note: For a 30 degree roof slope, the value of $C_{P}$ for the windward slope becomes -0.2 and

$$
\mathrm{p}=(27.32)(1.32)(-0.2)=-7.21 \mathrm{psf}
$$

from which the net horizontal load becomes

$$
p=-7.21-(-25.24)=18.03 p s f
$$

NET UPLIFT LOAD:

Windward Slope:

$$
\mathrm{p}=(27.32)(1.32)(-0.9)=-32.46 \mathrm{psf}
$$

Leeward Slope:

$$
\mathrm{p}=(27.32)(1.32)(-0.7)=-25.24 \mathrm{psf}
$$

Average Uplift:

$$
p=(-32.46-25.24) / 2=-28.85 p s f
$$

MAIN WIND FORCE RESISTING SYSTEM (MWFRS): (Table 4 and Figure 2)

\section{WALLS:}

Windward Wall:

$$
\mathrm{p}=(27.32)(1.32)(0.8)-(27.32)(-0.25)=35.68 \mathrm{psf}
$$

Leeward Wall:

$$
p=(27.32)(1.32)(-0.5)-(27.32)(0.25)=-24.86 p s f
$$

Sidewall (Endwall for wind normal to ridge):

$$
p=(27.32)(1.32)(-0.7)-(27.32)(0.25)=-32.07 p s f
$$


Net Drag Load:

$$
\mathrm{p}=(27.32(1.32)(0.8+0.5)=46.88 \mathrm{psf}
$$

ROOF:

Windward Slope:

$$
\mathrm{p}=(27.32)(1.32)(-0.9)-(27.32)(0.25)=-39.29 \mathrm{psf}
$$

Note: For a 30 degree roof slope, the value of $C_{p}$ for the windward slope becomes -0.2 and

$$
p=(27.32)(1.32)(-0.2)-(27.32)(0.25)=-14.04 p s f
$$

Leeward Slope:

$$
\mathrm{p}=(27.32)(1.32)(-0.7)-(27.32)(0.25)=-32.07 \mathrm{psf}
$$

Average Roof Uplift:

$$
\mathrm{p}=(-39.29-32.07) / 2=-35.68 \mathrm{psf}
$$

ROOF OVERHANGS: (Sec. 6.7.2.1)

Wind Normal to Ridge:

$$
\mathrm{p}=(27.32)(1.32)(-0.9-0.8)=-61.31 \mathrm{psf}
$$

Wind Parallel to Ridge:

$$
\mathrm{p}=(27.32)(1.32)(-0.7-0.8)=-54.09 \mathrm{psf}
$$

\section{COMPONENTS AND CLADDING: (Figure 3)}

Note: Width (a) of corner zones and roof perimeter zones is $10 \%$ of minimum width $[(0.1)(14)$ $=1.4$ feet $]$ or $0.4 \mathrm{~h}[(0.4)(11.4)=4.6$ feet $]$, whichever is smaller, but not less than either $4 \%$ of minimum width $[(0.04)(14)=0.56$ feet] or 3 feet. Therefore $(a)=3$ feet.

WALLS:

Interior Zone (zone 4):

A $\leq 10 \mathrm{ft}^{2}$

$$
\begin{aligned}
& p=(27.32)(1.4+0.25)=45.08 p s f \\
& p=(27.32)(-1.5-0.25)=-47.81 p s f
\end{aligned}
$$

$A \geq 500 \mathrm{ft}^{2}$

$$
\begin{aligned}
& p=(27.32)(1.0+0.25)=34.15 p s f \\
& p=(27.32)(-1.1-0.25)=-36.88 p s f
\end{aligned}
$$




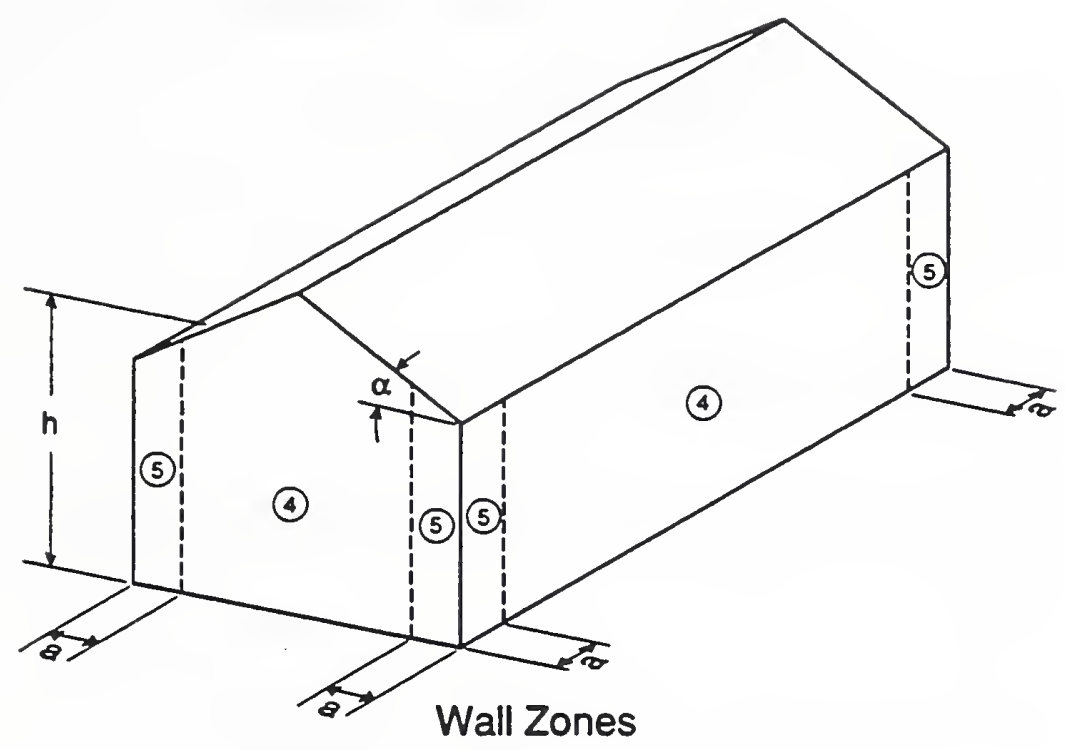

Corner Zone (zone 5):

$$
\begin{aligned}
& \mathrm{A} \leq 10 \mathrm{ft}^{2} \\
& \mathrm{p}=(27.32)(1.4+0.25)=45.08 \mathrm{psf} \\
& \mathrm{p}=(27.32)(-2.0-0.25)=-61.47 \mathrm{psf}
\end{aligned}
$$

\section{ROOF:}

Interior Zone (zone 1):

$$
\begin{aligned}
& \mathrm{A} \leq 10 \mathrm{ft}^{2} \\
& \mathrm{p}=(27.32)(-1.3-0.25)=-42.35 \mathrm{psf} \\
& \mathrm{A} \geq 100 \mathrm{ft}^{2} \\
& \quad \mathrm{p}=(27.32)(-1.1-0.25)=-36.88 \mathrm{psf}
\end{aligned}
$$

Edge Zone (zone 2):

$$
\begin{aligned}
& \mathrm{A} \leq 10 \mathrm{ft}^{2} \\
& \mathrm{p}=(27.32)(-3.0-0.25)=-88.79 \mathrm{psf} \\
& \mathrm{A} \geq 100 \mathrm{ft}^{2} \\
& \mathrm{p}=(27.32)(-2.0-0.25)=-61.47 \mathrm{psf}
\end{aligned}
$$


Corner Zone (zone 3):

$$
\begin{aligned}
A=9 \mathrm{ft}^{2} \\
\quad \mathrm{p}=(27.32)(-3.0-0.25)=-88.79 \mathrm{psf}
\end{aligned}
$$

Roof Trusses - Windward Slope:

$\operatorname{Span}=14 \mathrm{ft}:$

Tributary area $=(7)(7 / 3)=16.3 \mathrm{ft}^{2}$

Interior Zone (zone 1):

$$
\mathrm{GC}_{\mathrm{P}}=-1.25
$$

Edge Zone (zone 2):

$$
\mathrm{GC}_{\mathrm{P}}=-2.78
$$

Area-averaged exterior pressure coefficient:

$$
\begin{aligned}
& \mathrm{GC}_{\mathrm{P}}=[(4)(-1.25)+(3)(-2.78)] / 7=-1.91 \\
& \mathrm{p}=(27.32)(-1.91-0.25)=-59.01 \mathrm{psf}
\end{aligned}
$$

Span $=28 \mathrm{ft}:$

Tributary area $=(14)(14 / 3)=65.3 \mathrm{ft}^{2}$

Interior Zone (zone 1):

$$
\mathrm{GC}_{\mathrm{P}}=-1.14
$$

Edge Zone (zone 2):

$$
\mathrm{GC}_{\mathrm{P}}=-2.19
$$

Area-averaged exterior pressure coefficient:

$$
\begin{aligned}
& \mathrm{GC}_{\mathrm{P}}=[(11)(-1.14)+(3)(-2.19)] / 14=-1.36 \\
& \mathrm{p}=(27.32)(-1.36-0.25)=-43.99 \mathrm{psf}
\end{aligned}
$$


OVERHANGS: (Sec. 6.7.2.2)

Edge and Corner Zones:

$$
\begin{aligned}
& \mathrm{A} \leq 10 \mathrm{ft}^{2} \\
& \quad \mathrm{p}=(27.32)(-3.0)=-81.96 \mathrm{psf} \\
& \mathrm{A} \geq 100 \mathrm{ft}^{2} \\
& \quad \mathrm{p}=(27.32)(-2.0)=-54.64 \mathrm{psf}
\end{aligned}
$$

MANUFACTURED HOME CONSTRUCTION \& SAFETY STANDARDS (MHCSS):

DESIGN WIND LOADS:

$\S 3280.305(c)$ (2) Hurricane Resistive (Zone II)

$$
\text { Horizontal wind load }=25 \text { psf }
$$

Net uplift $=15$ psf

STABILITY OF STRUCTURE:

$\S 3280.306$ Windstorm Protection

$$
\begin{aligned}
& \text { Horizontal load }=(1.5)(25)=37.5 \mathrm{psf} \\
& \text { Uplift }=(1.5)(15)=22.5 \mathrm{psf}
\end{aligned}
$$

MAIN WIND FORCE RESISTING SYSTEM (MWFRS):

Windward Wall:

$$
\mathrm{p}=25 \mathrm{psf}
$$

Roof:

$$
\mathrm{p}=15 \mathrm{psf}
$$

COMPONENTS AND CLADDING:

$\S 3280.305$ (c) (3)(iii)

Eaves and Cornices:

$$
\mathrm{p}=(2.5)(15)=37.5 \mathrm{psf}
$$




\section{SOUTH FLORIDA BUILDING CODE - 1988:}

\section{DESIGN WIND SPEED:}

Sec. 2309.1(a)(2) requires a design wind speed of not less than $120 \mathrm{mph}$ at height of 30 feet above ground. However, it is not made clear whether this is a gust speed, fastestmile speed, or some other measure of wind speed.

Sec. 2309.1(g) \& (h) require the use of velocity pressures listed in Table 23-C. However, Sec. 2309.2(a) requires that the velocity pressures shall be taken as not less than either those in Table 23-C or as calculated from Equation 23-1. The calculated values are slightly higher, but the agreement between Table 23-C and Equation 23-1 is improved if 33 rather than 30 feet is taken as the reference height.

Sec. 2309.2(b)(2) requires habitable major structures located in the Coastal Building Zone to be designed to resist the applicable, predicted forces associated with a onehundred year storm event. However, no guidance is offered as to what the associated wind speed might be.

With this background, we shall assume the velocity pressures listed in Table 23-C apply. The associated wind speed of $120 \mathrm{mph}$ appears to be a gust speed because the shape factors specified for rectangular prismatic structures (Sec. 2309.3(b)(1) are identical to those of ASCE 7-88, and no gust factor is included in the load calculations. The corresponding basic wind speed is approximately $103 \mathrm{mph}$.

\section{VELOCITY PRESSURE:}

For height 0 to 5 feet, minimum velocity pressure $=22 \mathrm{psf}$

For height $>5$ to 15 feet, minimum velocity pressure $=27 \mathrm{psf}$

\section{STABILITY OF STRUCTURE:}

WALLS: (Sec. 2309.3(b)(1))

\section{Windward Wall:}

0 to 5 feet:

$$
p=(22)(0.8)=17.6 \mathrm{psf}
$$

5 to 15 feet:

$$
p=(27)(0.8)=21.6 \mathrm{psf}
$$

$$
\text { Area-averaged } \mathrm{p}=[(5)(17.6)+(5.5)(21.6)] / 10.5=19.70 \mathrm{psf}
$$


Leeward Wall:

$$
\begin{aligned}
& 0 \text { to } 5 \text { feet: } \\
& \qquad p=(22)(-0.5)=-11 \text { psf }
\end{aligned}
$$

5 to 15 feet:

$$
p=(27)(-0.5)=-13.5 p s f
$$

Area-averaged Load:

$$
p=[(5)(-11)+(5.5)(-13.5)] / 10.5=-12.31 \mathrm{psf}
$$

Net Horizontal Load:

$$
p=19.70-(-12.31)=32.01 \text { psf }
$$

ROOF: (Sec. 2309.3(b)(3)(aa))

Windward Slope:

$$
\mathrm{p}=(27)(-0.90)=-24.3 \mathrm{psf}
$$

Leeward Slope:

$$
p=(27)(-0.80)=-21.6 p s f
$$

Area-averaged Uplift:

$$
p=(-24.3-21.6) / 2=-22.95 \text { psf }
$$

Net horizontal load:

$$
p=-24.3-(-21.6)=-2.7 \mathrm{psf}
$$

OVERHANGS AND EAVES: (Sec. 2309.3(bb))

All Cases:

$$
p=(27)(-1.5)=-40.5 \mathrm{psf}
$$




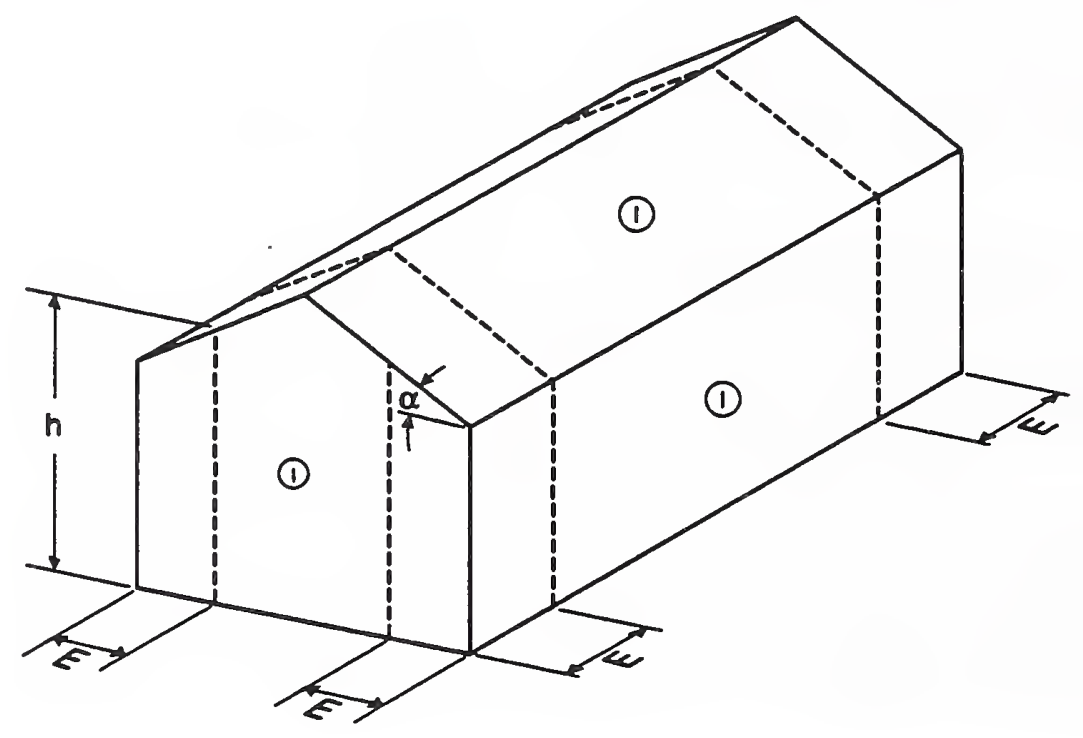

\section{VERTICAL SURFACES:}

End zone dimension $\mathrm{E}$ is minimum of $(0.2)(14)=2.8$ feet and $(0.8)(11)=8.8$ feet, but not less than $(0.08)(14)=1.12$ feet or 6 feet.

$\mathrm{E}=6$ feet

Note: The following values are for height range of 5 to 15 feet.

End Zone (zone E):

Windward Wall:

$$
\mathrm{p}=(27)(1.20)=32.4 \mathrm{psf}
$$

Leeward Wall:

$$
\mathrm{p}=(27)(-1.30)=-35.1 \mathrm{psf}
$$

Interior Zone (zone I):

Windward Wall:

$$
\mathrm{p}=(27)((1.12)=30.24 \mathrm{psf}
$$

Leeward Wall:

$$
\mathrm{p}=(27)(-1.12)=-30.24 \mathrm{psf}
$$


INCLINED ROOF SURFACES:

End Zone (zone E):

Windward:

$$
p=(27)(-1.67)=-45.09 p s f
$$

Leeward:

$$
p=(27)(-1.50)=-40.5 p s f
$$

Interior Zone (zone I):

Windward:

$$
p=(27)(-1.02)=-27.54 p s f
$$

Leeward:

$$
\mathrm{p}=(27)(-1.02)=-27.54 \mathrm{psf}
$$

STANDARD BUILDING CODE - 1991

BASIC WIND SPEED:

$\mathrm{V}=110 \mathrm{mph}$ (Figure 1205)

VELOCITY PRESSURE:

$\mathrm{p}=25 \mathrm{psf}($ Table 1205.2A)

USE FACTOR:

Use factor $=1.0($ Table 1205)

MAIN WIND FORCE RESISTING SYSTEM (MWFRS):

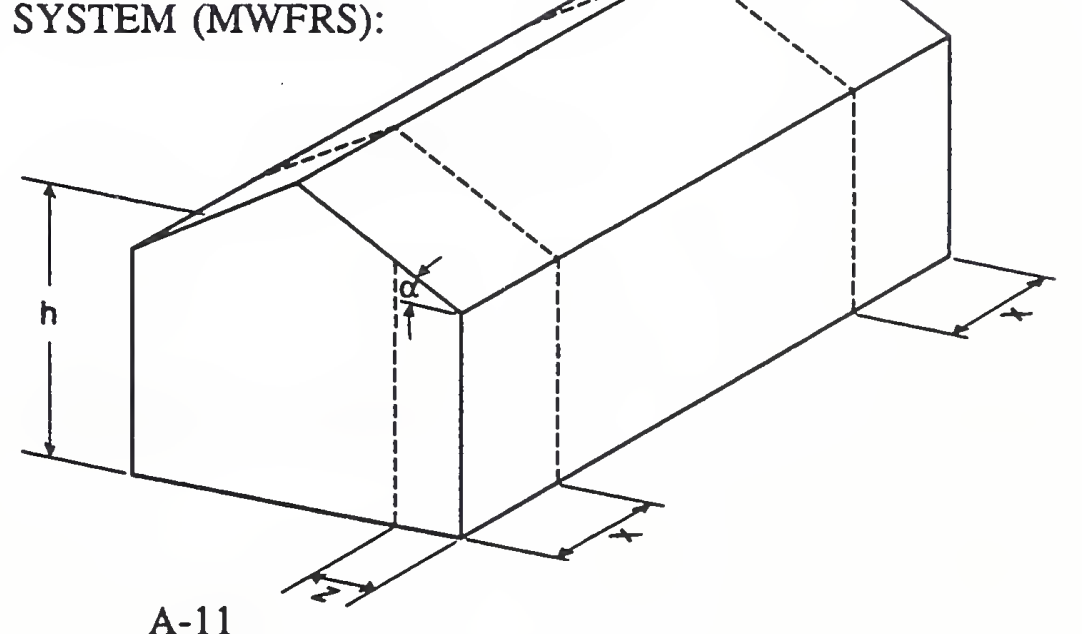


Edge strip $Z=$ lesser of $(0.1)(14)=1.4$ or $(0.4)(11.4)=4.6$, but not less than $(0.04)(14)=0.56$ and at least 3 feet.

$\mathrm{Z}=3$ feet

Zone width $Z=$ greater of 20 feet or $2 Z=(2)(3)=6$ feet.

$X=20$ feet

WALLS: (Table 1205.2B)

End Zone:

Windward Wall:

$$
\mathrm{p}=(25)(1.1)=27.5 \mathrm{psf}
$$

Leeward Wall:

$$
p=(25)(-0.95)=-23.75 p s f
$$

Interior Zone:

Windward Wall:

$$
\mathrm{p}=(25)(0.80)=20 \mathrm{psf}
$$

Leeward Wall:

$$
\mathrm{p}=(25)(-0.70)=-17.5 \mathrm{psf}
$$

ROOF: (Table 1205.2B)

End Zone:

Windward Slope:

$$
p=(25)(-1.4)=-35 p s f
$$

Leeward Slope:

$$
p=(25)(-1.0)=-25 p s f
$$

Interior Zone:

Windward Slope:

$$
p=(25)(-1.0)=-25 \mathrm{psf}
$$


Leeward Slope:

$$
\mathrm{p}=(25)(-0.75)=-18.75 \mathrm{psf}
$$

Note: Roof loads are less for wind in longitudinal direction.

AREA-AVERAGED LOADS:

Windward Wall $=[(27.5)(20)(2)+(20)(26)] / 66=24.55$ psf

Leeward Wall $=[(-23.75)(20)(2)+(-17.5)(26)] / 66=-21.29 \mathrm{psf}$

Windward Roof $=[(-35)(20)(2)+(-25)(26)] / 66=-31.06 \mathrm{psf}$

Leeward Roof $=[(-25)(20)(2)+(-18.75)(26)] / 66=-22.54 p s f$

Average Roof Load $=(-31.06-22.54) / 2=-26.80 \mathrm{psf}$

\section{NET DRAG LOAD:}

Note: Internal pressure coefficients removed from $\mathrm{GC}_{\mathrm{p}}$ values listed in Table 1205.2B.

Windward Wall:

End Zone:

$$
p=(25)(1.1+0.70) / 2=22.50 p s f
$$

Interior Zone:

$$
p=(25)(0.80+0.40) / 2=15 p s f
$$

Area-Averaged Drag Load:

$$
p=[(22.5)(20)(2)+(15)(26)] / 66=19.55 \mathrm{psf}
$$

Leeward Wall:

End Zone:

$$
\mathrm{p}=(25)(-0.95-0.55) / 2=-18.75 \mathrm{psf}
$$

Interior Zone:

$$
\mathrm{p}=(25)(-0.70-0.30) / 2=-12.50 \mathrm{psf}
$$

Area-Averaged Drag Load:

$$
p=[(-18.75)(20)(2)+(-12.50)(26)] / 66=-16.29 \mathrm{psf}
$$


Area-Averaged Net Drag Load:

$$
\mathrm{p}=19.55-(-16.29)=35.84 \mathrm{psf}
$$

End Zone:

$$
\mathrm{p}=(25)[1.1-(-0.55)]=41.25 \mathrm{psf}
$$

Interior Zone:

$$
\mathrm{p}=(25)[0.80-(-0.30)]=27.50 \mathrm{psf}
$$

Area-Averaged Net Drag Load:

$$
\mathrm{p}=[(41.25)(20)(2)+(27.50)(26)] / 66=35.83 \mathrm{psf}
$$

\section{NET UPLIFT LOAD:}

End Zone:

Windward Slope:

$$
\mathrm{p}=(25)(-1.4+0.2)=-30 \mathrm{psf}
$$

Leeward Slope:

$$
\mathrm{p}=(25)(-1.0+0.2)=-20 \mathrm{psf}
$$

Average Uplift:

$$
\mathrm{p}=(-30-20) / 2=-25 \mathrm{psf}
$$

Net Horizontal Load:

$$
p=-30-(-20)=-10 p s f
$$

Interior Zone:

Windward Slope:

$$
\mathrm{p}=(25)(-1.0+0.2)=-20 \mathrm{psf}
$$

Leeward Slope:

$$
p=(25)(-0.75+0.2)=-13.75 p s f
$$

Average Uplift:

$$
p=(-20-13.75) / 2=-16.88 p s f
$$

Net Horizontal Load:

$$
p=-20-(-13.75)=-6.25 p s f
$$


Area-Averaged Uplift Load:

$$
p=[(-25)(20)(2)+(-16.88)(26)] / 66=-21.80 p s f
$$

Area-Averaged Horizontal Load:

$$
p=[(-10)(20)(2)+(-6.25)(26)] / 66=-8.52 \mathrm{psf}
$$

OVERHANGS: (Table 1205.2D)

$$
\begin{aligned}
& p=(25)(0.2)=5 \text { psf } \\
& p=(25)(-1.5)=-37.5 p s f
\end{aligned}
$$

\section{COMPONENTS AND CLADDING:}

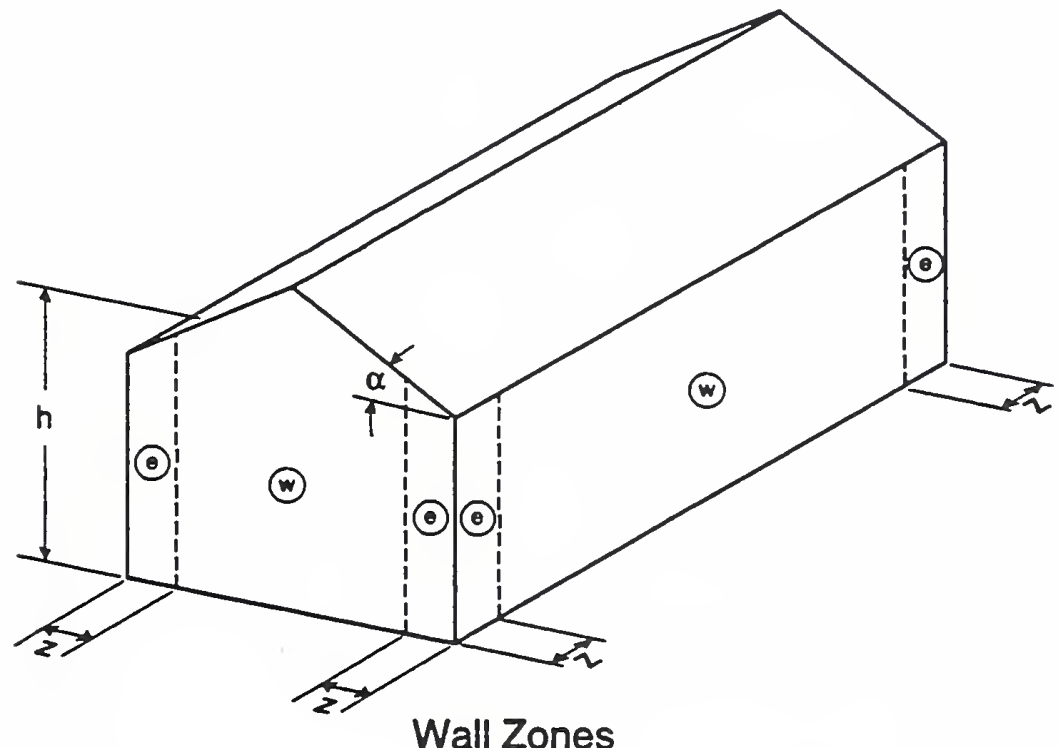

WALLS: (Figure 1205.2C)

Interior Zone (zone w):

$$
\begin{aligned}
& \mathrm{A} \leq 10 \mathrm{ft}^{2} \\
& \mathrm{p}=(25)(1.3)=32.5 \mathrm{psf} \\
& \mathrm{p}=(25)(-1.3)=-32.5 \mathrm{psf} \\
& \mathrm{A} \geq 500 \mathrm{ft}^{2} \\
& \mathrm{p}=(25)(1.0)=25 \mathrm{psf} \\
& \mathrm{p}=(25)(-1.1)=-27.5 \mathrm{psf}
\end{aligned}
$$

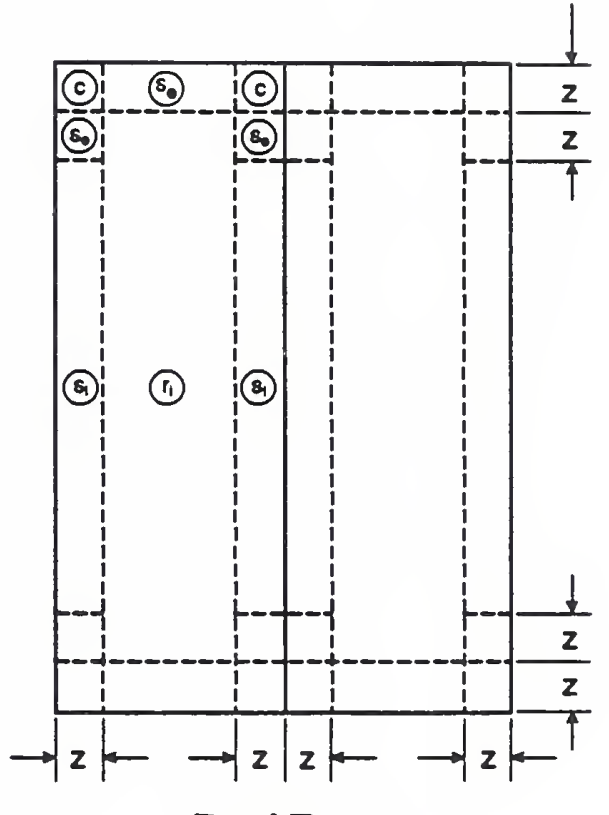

Roof Zones 
Corner Zone (zone e): $(Z=3$ feet)

$$
\begin{aligned}
& \mathrm{A} \leq 10 \mathrm{ft}^{2} \\
& \quad \mathrm{p}=(25)(1.3)=32.5 \mathrm{psf} \\
& \mathrm{p}=(25)(-1.5)=-37.5 \mathrm{psf} \\
& \mathrm{A}=25 \mathrm{ft}^{2} \\
& \mathrm{p}=(25)(1.22)=30.5 \mathrm{psf} \\
& \mathrm{p}=(25)(-1.4)=-35 \mathrm{psf}
\end{aligned}
$$

ROOF: (Figure 1205.2E)

Note: These calculations reflect corrections of Sep/Oct 92 to SBC-91.

Interior Zone (zone $\mathrm{r}_{\mathrm{i}}$ ):

$$
\begin{aligned}
& \mathrm{A} \leq 10 \mathrm{ft}^{2} \\
& \mathrm{p}=(25)(-1.2)=-30 \mathrm{psf} \\
& \mathrm{A} \geq 100 \mathrm{ft}^{2} \\
& \quad \mathrm{p}=(25)(-1.1)=-27.5 \mathrm{psf}
\end{aligned}
$$

Edge Zones: $(Z=3$ feet $)$

At Sidewall (zone $\mathrm{s}_{\mathrm{i}}$ ):

$$
\begin{aligned}
& \mathrm{A} \leq 10 \mathrm{ft}^{2} \\
& \mathrm{p}=(25)(-1.4)=-35 \mathrm{psf} \\
& \mathrm{A} \geq 100 \mathrm{ft}^{2} \\
& \quad \mathrm{p}=(25)(-1.2)=-30 \mathrm{psf}
\end{aligned}
$$

At Gable End \& Adjacent to Corner (zone $s_{e}$ ):

$$
\begin{aligned}
& \mathrm{A} \leq 50 \mathrm{ft}^{2} \\
& \mathrm{p}=(25)(-2.1)=-52.5 \mathrm{psf} \\
& \mathrm{A} \geq 100 \mathrm{ft}^{2} \\
& \quad \mathrm{p}=(25)(-1.8)=-45 \mathrm{psf}
\end{aligned}
$$

Corner Zone (zone c):

$$
\begin{aligned}
& A \leq 10 \mathrm{ft}^{2} \\
& \quad \mathrm{p}=(25)(-2.7)=-67.5 \mathrm{psf}
\end{aligned}
$$




$$
\begin{aligned}
& A \geq 100 \mathrm{ft}^{2} \\
& \quad \mathrm{p}=(25)(-1.8)=-45 \mathrm{psf}
\end{aligned}
$$

OVERHANGS: (Figure 1205.2E)

Sidewalls (zone $\mathrm{s}_{\mathrm{i}}$ ):

$$
\begin{gathered}
\mathrm{A} \leq 10 \mathrm{ft}^{2} \\
\mathrm{p}=(25)(-1.8)=-45 \mathrm{psf} \\
\mathrm{A} \geq 100 \mathrm{ft}^{2} \\
\quad \mathrm{p}=(25)(-1.55)=-38.75 \mathrm{psf}
\end{gathered}
$$

Gable Ends \& Corners (zones $\mathrm{s}_{\mathrm{e}}$ and $\mathrm{c}$ ):

$$
\begin{aligned}
& \mathrm{A} \leq 10 \mathrm{ft}^{2} \\
& \mathrm{p}=(25)(-2.5)=-62.5 \mathrm{psf} \\
& \mathrm{A} \geq 100 \mathrm{ft}^{2} \\
& \quad \mathrm{p}=(25)(-1.6)=-40 \mathrm{psf}
\end{aligned}
$$



